

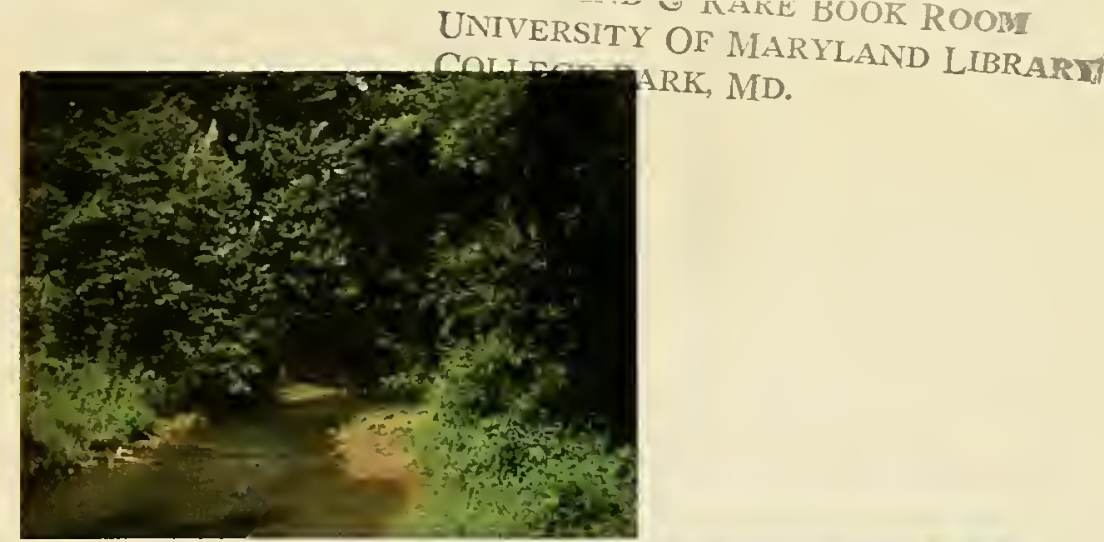

RK, MD.
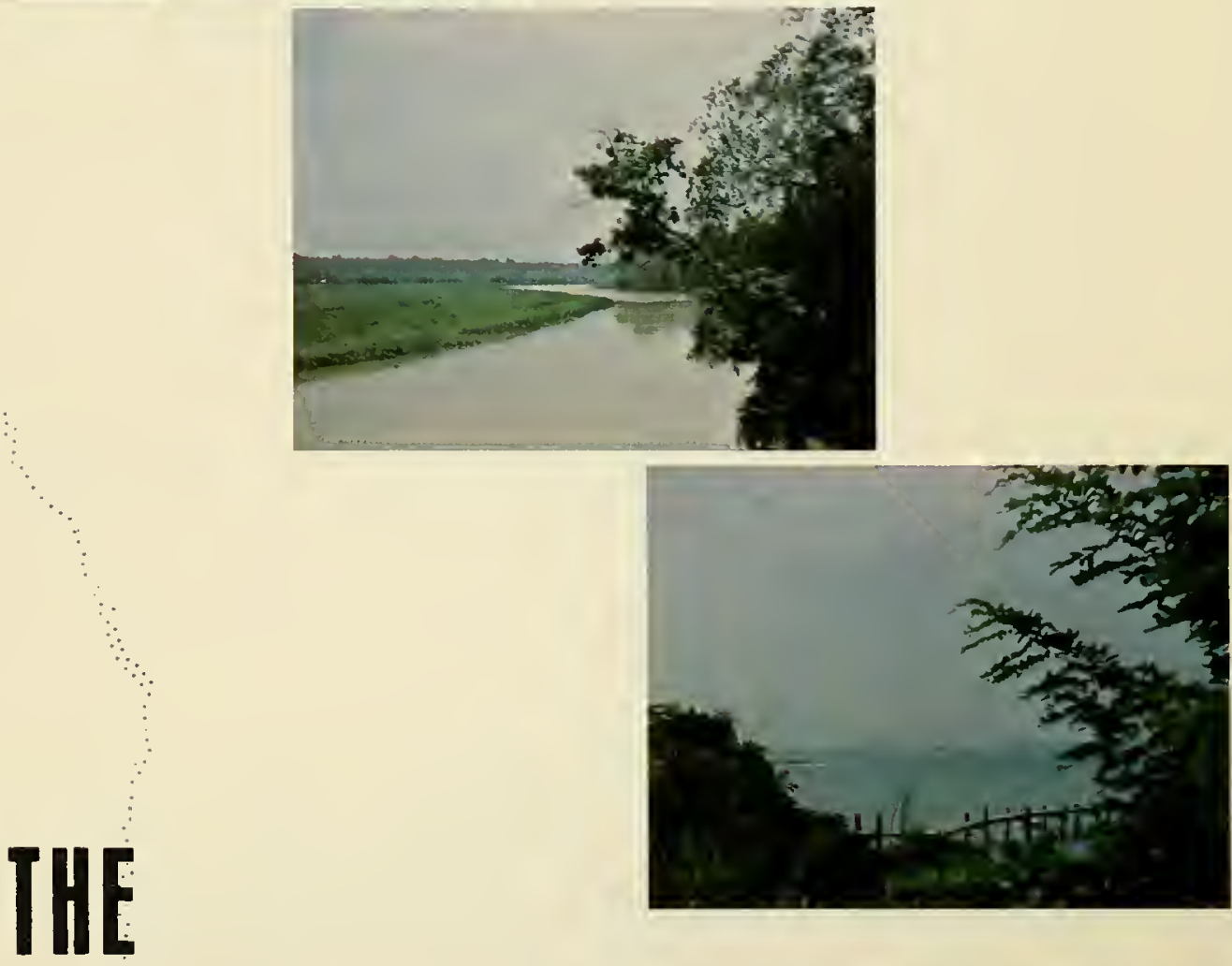

PATUXENT RIVER

\section{MARYLANDS}

\section{ASSEI,}

MaRYLANDS

RESPONSIBILITY

GOVERNOR'S PAIUXENT RIVER WATERSHED

ADVISORY GOMMITTEE 


\title{
Picture Locations
}

\author{
Route $94 \quad$ Howard-Montgomery County Line \\ Route $4 \quad$ Waysons Corner \\ Vicinity of Half Pone Point, Calvert-St. Mary's Counties.
}

MARYLAND STATE PLANNING DEPARTMENT

1103 State Office Building

Baltimore, Maryland 21201 
Report on a Re-Examination of the Water and Related Land Resource

Problems of the Patuxent River Basin

STATE OF MARYLAND

SPIRO T. AGNEW, GOVERNOR

PREPARED IN COOPERATION WITH THE U.S. DEPARTMENT OF THE INTERIOR FEDERAL WATER POLLUTION CONTROL ADMINISTRATION

GOVERNOR'S PATUXENT RIVER WATERSHED ADVISORY COMMITTEE 


\section{Digitized by the Internet Archive in 2010 with funding from \\ Lyrasis Members and Sloan Foundation}


Honorable Spiro T. Agnew

Governor of Maryland

The state House

Annapolis, Maryland

Dear Governor Agnew:

The Governor's Patuxent River Watershed Advisory Committee has met on numerous occasions during the past three years in its study of the problems of the Patuxent River Basin. We are gratified with the foresight and support shown by Governor Tawes and yourself in regard to environmental quality in the state and specifically the Patuxent River Watershed.

In connection with its task, the Committee requested the Maryland State Planning Department to prepare a report on the problems of the Watershed. Pursuant to this request, the Report on a Re-Examination of the Water and Related Land Resources Problems of the Patuxent River Basin was prepared by Melvin E. Scheidt, consultant for the planning Department. The members of your Advisory Committee have reviewed this report and approve its findings and recommendations. In view of this, the Committee is herewith presenting this report to you for your review.

The Committee hopes that you will concur with its approval of this report and the recommendations contained therein and will make every effort to see that RAPID implementation of these recommendations is carried out by the appropriate state agencies. The Committee feels that the problems of the Watershed can only be alleviated by the adoption of these recommendations and strict enforcement of their provisions.

In its work, the Committee received splendid cooperation and help from various Federal, state and local governmental agencies constituting the Patuxent Technical Task Force and wishes to state its appreciation to these organizations. It wishes to particularly extend its appreciation to Robert M. August of the staff of the Maryland State Planning Department; Melvin E. Scheidt, consultant for the Planning Department; Johan Aalto, Dr. Leo Hetling and Dr. Norbert Jaworski of the Federal Water Pollution Control Administration; and W. Porter Ellington of the Department of Legislative Reference, for services performed for the Advisory Committee.

John T. Parran, Chairman

Leonard S. Blondes

John H. Briscoe

James Clark

Bennie C. Dowell

Donald W. Roberson

John W. Steffey 



\section{LETTER OF TRANSMITTAL}

\section{MEMBERS OF PARTICIPATING COMMITTEES AND AGENCIES}

FINDINGS AND RECOMMENDATIONS ... . . . . . . . . . . . i

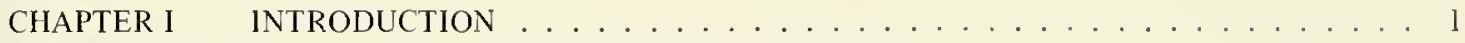

CHAPTER II DESCRIPTION OF THE PATUXENT BASIN $\ldots \ldots \ldots \ldots \ldots$

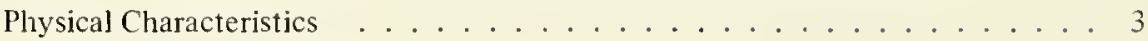

Culture, Industry and Population $\ldots \ldots \ldots$

Previous and Existing Water and Land

Management Activities ................. . 5

Problems of the Basin .................... 8

CHAPTER III WASTE WATER DISPOSAL AND STREAM QUALITY CONTROL . . . . . 10

CHAPTER IV PRESERVATION AND ENHANCEMENT OF THE ESTUARY $\ldots \ldots \ldots$

CHAPTER V SOIL EROSION AND SEDIMENTATION CONTROL $\ldots \ldots \ldots$

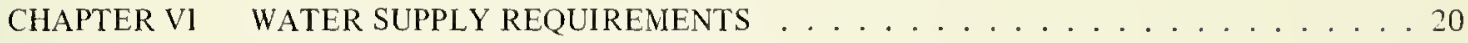

CHAPTER VII PARK, RECREATIONAL AND OPEN SPACE LAND ACQUISTION

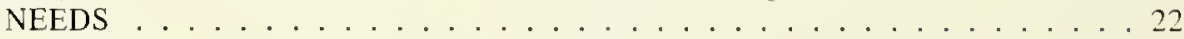

CHAPTER VIII ORGANIZATIONAL ARRANGEMENTS $\ldots \ldots \ldots \ldots \ldots \ldots$

General Considerations . . . . . . . . . . . . . . . . . 25

Waste Water Disposal . . . . . . . . . . . . . . . 26

Regional Water Supply Coordination . . . . . . . . . . . 28

Park, Recreational and Open Space Planning and

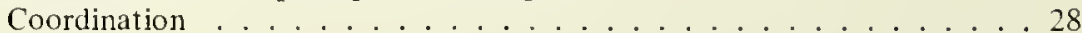

Erosion and Sediment Control . . . . . . . . . . . . . . . . . 29

Further Investigations in the Estuary . . . . . . . . . . . . . 29

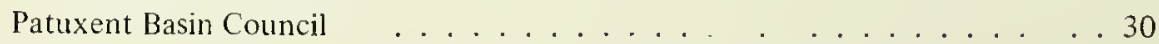

TABLE I COUNTY AND PATUXENT BASIN POPULATION PROJECTIONS . . . . . . 6

TABLE 2 PATUXENT REGIONAL SEWERAGE REPORT-POPULATION PROJECTIONS . 10

TABLE 3 MAJOR MUNICIPAL AND INDUSTRIAL WASTE WATER DISCHARGES

PATUXENT RIVER BASIN $\ldots \ldots \ldots \ldots \ldots \ldots \ldots \ldots \ldots \ldots$

FIGURE I $\quad$ PATUXENT RIVER BASIN $\ldots \ldots \ldots \ldots \ldots \ldots \ldots \ldots \ldots$

\section{APPENDICES TO MAIN REPORT}

Appendix A - Transmittal Letter -James J. O'Donnell to John T. Parran. Jr., Chairman, Governor's Patuxent River Watershed Advisory Committee, June 4, 1968.

Appendix B - Maryland State Planning Department-"Historical Record of the Patuxent Watershed Study Program and Comments on the Findings and Recommendations." 

Room 513 Ames Hall

The Johns Hopkins University

Baltimore, Maryland 21218

February 14, 1968

Mr. James J. O'Donnell, Director

Maryland State Planning Department

State Office Building

Baltimore, Maryland 21201

Dear Mr. O'Donnell:

In accordance with my agreement with the Maryland State Planning Department dated August 9, 1967, I submit herewith my report on an evaluation of the water and related land resource management problems of the patuxent River Basin.

The report deals with the problems of quality and quantity of water in the basin, waste water disposal, public water supply, park, recreational and open space requirements, the effects of rubbish disposal on the basin's environment, erosion and sediment control, and preservation and enhancement of the tidal estuary in the lower third of the basin. In studying these problems, the impact and influence of bordering rapidly expanding metropolitan regions of Baltimore and Washington, developing new towns of Columbia and Bowie-Belair, and other subdivision developments in the center of the basin have been given due consideration, as have related economic and social factors which affect, or are likely to affect, the basin in the future.

The report presents the findings regarding the facilities and measures which will be required to deal with the several problems discussed, and the additional investigations which will be required before solutions can be found in those situations where inadequate information is now available. The report also presents a series of recommendations for immediate and future actions designed to implement the measures proposed, and also proposes a set of organizational arrangements for undertaking the implementing actions.

A summary of pertinent findings and conclusions is presented in the forefront of the report for quick reference.

This report was prepared in cooperation with the Patuxent Basin Technical Task Force, consisting of departmental and regional agency technical personnel assembled to aid and help guide the study, and the Federal water pollution Control Administration. The FWPCA has been studying the basin's water pollution problems since 1966, and made its findings fully available to this consultant and to the Task Force in the course of the study. The findings of the FWPCA have been heavily relied upon in drawing the conclusions presented in the report, and the technical report of that agency has therefore been appended as an important substantiating document. The report herewith submitted should accordingly be looked upon as a cooperative undertaking by the State of Maryland and the Federal water pollution Control Administration insofar as water quality and waste water problems are concerned.

In the course of preparing the report, conferences were held with the Governor's Patuxent River Watershed Advisory Committee and the governing councils or boards of commissioners of all of the counties of the basin. Various drafts of the report were also discussed in detail with the Technical Task Force, which included representatives of all of the affected or interested state agencies, the five regional agencies having jurisdiction in the basin, and the FWPCA. These various agencies and their representatives are set forth on an adjacent page of the report listing the organizations and representatives who participated in the study.

It is with a deep sense of gratitude that I record here the universal good will and cooperativeness of all of these people which was accorded me in connection with this study. Finally, I take great pleasure in expressing my thanks to Mr. Robert August of the staff of the state Planning Department for his unfailingly cheerful and thoughtful assistance to me throughout the undertaking.

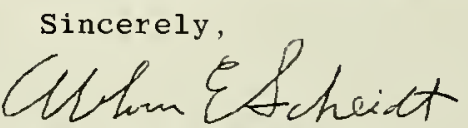

Melvin E. Scheidt

Consulting Engineer 

Anne Arundel County

Senator John Steffey

Calvert County

Bennie C. Dowell

Charles County

John T. Parran, Jr., Chairman
Howard County

Senator James Clark

Montgomery County

Delegate Leonard S. Blondes

Prince George's County

Donald W. Roberson

St. Mary's County

Delegate John H. Briscoe, Jr.

\section{PATUXENT TECHNICAL TASK FORCE}

State Planning Department-Chairman Agency

Robert M. August

W. Leon Etzler

Chesapeake Biological Laboratory

Dr. Joseph T. Mihursky

Department of Forests and Parks

Edward I. Heath

Department of Game and Inland Fish

James Goldsberry

\section{Department of Health}

Thomas D. McKewen

Alt: Charles E. Gross

Department of Water Resources

James J. Allison

Alt: Robert Pierce

Charles Hall

Department of Chesapeake Bay Affairs

Frederick W. Sieling

Alt: Edgar H. Hollis

Fort George G. Meade

George E. Cunningham

Alt: Gordon Remsburg
Maryland Geological Survey

Harry Hansen

Maryland-National Capital Park and

Planning Commission

Robert Arciprete

Jorge Valladares

Regional Planning Council

Allen Leary

State Roads Commission

John Lentz

Tri-County Council for Southern

Maryland

William Anders

John Mills

Washington Suburban Sanitary Commission Dr. Alfred Machis

Alt: Stephen Profilet

Metropolitan Washington Council of

Governments

Frank Price

Alt: John Lentz

\section{FEDERAL WATER POLLUTION CONTROL ADMINISTRATION}

Johan A. Aalto

Dr. Leo J. Hetling

Dr. Norbert A. Jaworski 


(1)




\section{The Basin and Its Problems}

The Patuxent is the largest intra-state river in Maryland. It extends in a long, narrow band southeastward through central Maryland between the rapidly growing nearby metropolitan centers of Baltimore and Washington and empties into the Chesapeake Bay in Southern Maryland.

The river traverses three distinct physiographic regions. Its upper third, in Howard and Montgomery counties, lies in the rolling upland Piedmont Plateau. The streams in this area are swift and clear and receive little if any polluting discharges. The middle reach, located principally in Anne Arundel and Prince George's counties, occupies the upper coastal plain. This reach has a wide, flat, swampy and heavily forested flood plain and sluggish streams. Most of the waste waters of the basin are conveyed to and discharged into the streams of this portion of the basin after treatment. The lower third of the basin, lying in Charles, Calvert and St. Mary's counties, is characterized by the long, narrow tidal estuary, an arm of the Chesapeake Bay. The upper fifteen miles of this estuary has been filled with silts eroded from the watershed during the past 300 years and conveyed to the estuary by the Patuxent.

The basin was, until the end of World War II, essentially rural in character throughout its entire length.

Urban, suburban and industrial developments are now rapidly encroaching into the upper and middle portions of the basin from both the Baltimore and Washington areas and entire new towns, such as Columbia and Bowie-Belair, are springing up within the basin.

This intensive urban development is making increasing demands upon the basin for waste water disposal, water supply, space in the river's bed for storage of sediments eroded from construction sites and disposal of rubbish along the shores. At the same time the basin is being called upon to provide attractive water surfaces and land areas for recreation and esthetically pleasing environmental values.

Waste waters discharged into the streams of the middle reach, even though given what has been considered good treatment, have begun to degrade the quality of the receiving waters in a few locations. Several solid waste disposal areas along the river have created unsightly conditions as well as causing some water pollution. With the exception of these few correctable conditions, however, the river and its bordering lands still remain essentially unspoiled and continue to provide an attractive land and water environment for the people of the region.

The present condition of the basin cannot long continue. The river and bordering lands, especially in the middle reach and upper estuary portions of the basin, are threatened with early destructive pollution and unsightly degradation unless immediate steps are taken to prevent this from happening.

Five problems require immediate attention if the basin's attractive qualities are to be preserved and the few existing local breakdowns in environmental quality are to be corrected. These are:

1. Waste water disposal

2. Preservation and enhancement of the estuary

3. Control of erosion and sedimentation

4. Public water supply

5. Provision of park, recreational and open space lands.

Disposal of solid waste is associated with the latter problem. Because water quality is important in all of them, the effects of waste water disposal on water quality is the most important of these problems to be dealt with.

\section{Waste Water Disposal}

Results of field investigations in the middle reach of the basin conducted by the Federal Water Pollution Control, in cooperation with the Maryland Departments of Water Resources and Health, disclosed that the river and its tributaries in this reach do not possess the waste assimilation capacity previously believed to have existed. A clearly discernible, progressively downward trend in the water quality of the river has developed over the past several years. Dissolved oxygen has been found in some areas to be depressed on occasion to well below the minimum levels prescribed by the State water quality standards, causing the destruction of eggs and newly hatched fry and disappearance of some species of fish. Nutrients, such as nitrogen and phosphorus, which are not removed from waste water by conventional treatment, have increased in concentration in the upper estuary to where objectionable algal blooms such as those which occur annually in the upper Potomac estuary at Washington are incipient. However, the probable effects upon the upper 
estuary of effluents discharged into it from treatment plants being built in the Western Branch area have not yet been determined as much additional study of the estuary is needed.

Populations in the basin are projected to triple between 1960 and 1980. Waste water discharge volumes are estimated to increase eight fold during the period. This is a much greater rate of increase than that used in designing the existing waste water treatment system of the basin.

The degree of treatment presently being given waste waters discharged to the river is inadequate for the demands on the river which are now developing.

\section{The Tidal Estuary and Its Pollution Problems}

lnsufficient biological, physical and chemical analyses are available to permit a full understanding of the behavior of the tidal estuary and its waste assimilative capacity and related functions. Studies currently planned by the Natural Resources Institute of the University of Maryland and the Federal Water Pollution Control Administration will assist in providing some, but not all, the data and analyses required for such an understanding.

\section{Erosion and Sediment Control}

Fifteen miles of the original tidal estuary of the Patuxent have been filled with silt since colonial times. Although the rate of siltation is presently much less than in earlier years because of improved farming practices, erosion from construction sites is far greater than that ever experienced even under the poor farming practices of earlier days. A tremendous increase in the amount of sediment transported to the estuary can therefore be anticipated unless measures are adopted to control erosion at all construction sites in the basin.

Montgomery County now requires the application of measures for the control of erosion at all construction sites and subdivision developments. Howard, Prince George's and Charles counties are about to adopt similar requirements. The State Roads Commission provides for similar requirements on federally aided highway construction.

\section{Public Water Supply}

The Patuxent Basin now furnishes 45 to 50 million gallons of water daily to the Washington suburban area, lying for the most part outside of the Patuxent Basin.

No more water for public water supply should be taken from surface streams in the basin. The remaining water flowing in the basin's streams is required to support fish life, assimilate treated wastes, and preserve the esthetic and environmental qualities of the basin. Ground water is adequate for supplies in the three southern counties, but not for the more heavily built-up areas in the middle reach and upper portion of the basin.*

Future water supply requirements in the basin must therefore come from the Baltimore and Waslington supply systems or other sources outside the basin.

Comprehensive studies of future water supply requirements are now being undertaken by the Regional Planning Council (Baltimore) the Metropolitan Washington Council of Governments and by Fort Meade.

\section{Park, Recreational and Open Space Requirements and Programs}

The Patuxent Watershed Act of 1961 now authorizes the counties of the basin to acquire streamside park, recreational, and open space land throughout the basin as a means of preventing encroachment on the river and its tributaries, preserving the environment and the amenities of the basin and its streams and controlling flood damage and erosion.

The State Department of Forests and Parks is acquiring and developing the Patuxent State Park on the headwaters of the main Patuxent River above Triadelphia Reservoir with funds provided by the State Legislature.

The Washington Suburban Sanitary Commission owns two water supply reservoirs on the main Patuxent River between Laurel and Triadelphia. These reservoirs and their surrounding lands possess great recreational values, some of which are already available to the public through appropriate provisions of the Commission.

Extensive additional park, recreational and open space lands will be required in the basin in the future to provide for a wide variety of facilities, activities, amenities, and environmental influences as population increases within the basin.

The existing land acquisition programs under the 1961 Act and the State Park Program will not be able to provide for all the different kinds of park and recreational activities or influences required in the future.

*The Maryland Geological Survey has indicated that ground water is available in the middle reach. (See page 21) In this regard both Anne Arundel County and Fort Meade anticipate substantial development of ground water supplies. 


\section{RECOMMENDATIONS}

1. Expanded and new waste treatment facilities, as well as an increase in level of treatment, will be required to meet the anticipated increased waste loads. Waste water treatment must be sufficient to remove $94 \%$ and $96 \%$ of the-organic substances, for loads up to 1980 and 2000 respectively, instead of the presently prescribed $90 \%$ for loads up to 2000 . In addition, releases of water from the Rocky Gorge Reservoir* to maintain a flow in the river of 20 cubic feet per second will be required to further assimilate the treated effluents.

2. A three-stage waste treatment program is required to fully restore and preserve the water quality of the basin.

a. All existing wastewater treatment plants must be immediately brought to their maximum level of operating efficiency. Permits for subdivision development should be reexamined to ensure that adequate capacity exists for treating the wastes generated. Where such treatment is found to be inadequate, the permits should be suspended until additional facilities are provided. The State Department of Health should immediately undertake these activities.

b. A new basin-wide wastewater treatment and disposal system nust be planned, based on the anticipated increased waste loads to 1980 and the increased level of treatment indicated to be needed. This system should be planned cooperatively by all jurisdictions in the basin.and should be completed by 1970 to permit the counties to include the facilities indicated to be needed in their comprehensive programs required by Senate Bill 335 (County Sewer and Water Facilities Planning Program) adopted by the Legislature in 1966.

c. For the longer range requirements of the basin up to the year 2000 , a cooperative study of a wider range of alternatives for disposing of the basin's wastes is needed. Alternatives such as diversion of the treated wastes to the lower estuary, the Bay or Ocean, mechanical aeration, complete renovation and land spreading all should be evaluated.

3. A Patuxent Basin Sanitary Advisory Committee should be organized immediately to initiate and coordinate preparation of the 1970 program of new and expanded facilities required up to 1980. Thereafter, the Committee should undertake on a continuing basis the studies and analyses required to plan the longer range program for the future. This Committee should also concern itself with the long range problems of water supply in the basin and with the disposal of solid wastes. The Committee should include representatives from all of the basin county sanitary departments, the Washington Suburban Sanitary Commission, the Maryland-National Capital Park and Planning Commission, the Metropolitan Washington Council of Governments, the Regional Planning Council for the Baltimore area, the Maryland Department of Water Resources and the Maryland State Department of Health. The latter agency should assume immediate responsibility for organizing the Committee and should provide it with secretarial service.

4. The Governor should request the FWPCA for direct technical assistance in studying and analyzing the estuary, and the State Health, Water Resources, and Chesapeake Bay Affairs Departments and the Natural Resources Institute should all participate in these studies. As data and findings become available from the estuary studies, they should be made available to the Sanitary Advisory Committee for use by that Committee in connection with its waste water disposal system planning program.

5. All counties should anticipate the need for advanced waste treatment for the removal of nutrients when providing for land and planning the layout of their waste water treatment plants. Should the estuarine studies called for confirm the present indications of an early need for such advanced waste treatment, the necessary plant additions should be immediately planned and constructed to prevent the threatened further degradation of the estuary.

6. Erosion control measures should be extended to the entire basin.

7. The Maryland Department of Water Resources should immediately undertake the organization of an Erosion and Sedimentation Control Committee to coordinate and guide the preparation, adoption and implementation of measures for erosion control throughout the basin. The Erosion Control Committee

* Recently re-named the T. Howard Duckett Reservoir 
should include the soil conservationist of each county, a representative of each county soil conservation district, the State Conservationist of the United States Department of Agriculture, a representative of the department of each county charged with administering the erosion control measures and a representative of the State Roads Commission.

8. The comprehensive studies now being undertaken by the Regional Planning Council (Baltimore), Metropolitan Washington Council of Governments and by Fort Meade should be coordinated to ensure that the future water supply requirements of the basin are adequately recognized and provided for in these investigations and resulting plans and recommendations. The State Planning Department should assume the responsibility for bringing together the appropriate representatives of these agencies, and their consultants, to effect the needed basin-wide coordination of public water supply planning and provision.

9. A more comprehensive, coordinated approach to park, recreational open space planning in the basin is required. The provision of park, recreational and open space lands in the Patuxent Basin must be looked at from the point of view of the entire Baltimore-Washington Metropolitan complex-not just that of the basin alone.

10. A Baltimore-Washington Metropolitan Park, Recreational and Open Space Advisory Committee is needed to analyze, evaluate the needs and coordinate the planning for and provision of park, recreational and open space land in the entire bi-city metropolitan complex. This Committee should also concern itself with the relationship of solid waste disposal landfills to the problem of providing parks and open spaces and of preserving the esthetic qualities of the basin. For this purpose it should maintain liaison with the Sanitary Advisory Committee. The Committee should also explore ways of arranging with the Washington Suburban Sanitary Commission for more complete utilization of the recreational capabilities of its two reservoirs and surrounding lands.

11. The Park, Recreational and Open Space Advisory Committee should consist of representatives from all of the seven county planning commissions or departments in the basin, the Maryland-National Capital Park and Planning Commission, the Baltimore, Washington and Tri-County regional councils, the respective park boards or departments of all counties of the basin which have them, the Washington Suburban Sanitary Commission, and the State Departments of Forests and Parks, Chesapeake Bay Affairs and Game and Inland Fish. The State Planning Department should also be a member and should assume responsibility for organizing the Committee. The State Planning Department should provide secretarial service.

12. A Patuxent Basin Council of elected representatives from the seven counties of the basin is required to finance the work of the several advisory committees recommended, review their recommendations and coordinate the financing, acquistion, construction or other implementation of the programs agreed upon. The Council should consist of one representative from each county council or board of commissioners, and one representative from the elected delegation to the Legislature from each county, together with a representative from the Governor's Office. It is recommended that in selecting the member of each basin county governing body to represent the county on the Patuxent Basin Council, that the individual who represents the county on the Baltimore, Washington or Tri-County regional councils be chosen as a means of coordinating the affairs of the Basin Council with those of the three regional councils. This procedure also has the effect of knitting together the entire Baltimore-Washington Metropolitan region. 


\section{CHAPTER I}

\section{INTRODUCTION}

The Patuxent River Basin possesses a unique significance for the people of Maryland. It is the largest of the very few river basins of the State which lie entirely within the State. As such it is, of course, totally within the control of the people of Maryland and therefore offers a splendid opportunity to devise and demonstrate effective methods of managing the land and water resources of an intra-state stream. Of more significance, however, is that it lies squarely between the rapidly expanding metropolitan centers of Baltimore and Washington with its main stem forming the boundary between these two regions and their bordering counties.

Until the end of World War II, this inter-city basin was almost entirely rural in character. Since that time and especially within the last 10 or 15 years, the rapid expansion of suburban subdivision, new town and industrial developments into the four upper counties of the basin has brought about swift population increase in the basin and an intensive, as well as an extensive, occupancy of lands formerly devoted to farming.

The Baltimore-Washington Metropolitan complex is growing at a more rapid rate than any other metropolitan area in the nation. 1ts population is expected to increase from nearly five million in 1967 to about nine million by the year 2000 . Metropolitan populations within and immediately adjacent to the basin, excluding the District of Columbia, Virginia and northern Maryland areas, totalled nearly two and a half million in 1960 and will double by 2000. Of greater significance, however, is the fact that population in the four upper counties of the basin is increasing at more than twice the rate of the bi-city region as a whole, and population growth in the lower three counties will eventually accelerate also.

This rapid growth is not only changing the character of land use in the basin, but is placing increasing demands upon the resources of the river and its bordering lands for various public purposes. As the population has increased, public water supply and waste water disposal systems have had to be constructed, with resulting demands upon the river and its tributaries for both water supply and disposal of waste water. Increasing demands for recreational space are resulting in an expanding need for additional park and open space land. Much additional space is being required to dispose of rubbish, garbage and other solid wastes. River bottoms, wetlands and other so-called "wastelands" are often erroneously sought out for this purpose, to the detriment of the streams and their bordering lands. Erosion from construction and subdivision sites is increasingly pre-empting the river's bed and the estuary for storage space for sediments. At the same time, water oriented activities such as fishing, boating and swimming are not only causing greater use pressures upon the water surface of the basin's streams, reservoirs and the estuary, but require that the waters involved be of satisfactory quality to support these activities.

Up to now these uses and demands have caused degradation of quality in the waters or bordering lands of the river in only limited local areas. Waste water treatment facilities in accord with previously acceptable standards have been provided as needed under a program prepared in 1961 jointly by the affected cities, counties, regional agencies and the State Department of Health. Parks and open spaces are slowly being set aside by several of the counties and the State with the aid of State and Federal funds provided under several legislative acts, including the Patuxent Watershed Act of 1961. Solid waste disposal has so far encroached upon the banks of the river at only one or two places. Thus, while as pointed out later in this report, there is a clearly discernible general trend toward degradation of both land and water quality and populations as land occupancy increase, and even more serious polluted conditions have occurred at several specific locations, the river and its shores, including the important tidal estuary in the lower third of the basin, have not yet in general become so polluted or desecrated as to seriously interfere with the various uses and demands places upon the river and its lands.

Here, then, stretching south and southeastward for 110 miles in a long, narrow band through central Maryland between and in close proximity to two of the nation's largest and most rapidly growing metropolitan areas, is a river basin which is still essentially unspoiled. It offers a pleasing natural environment for the enjoyment of outdoor pursuits, both passive and active, and provides a highly desirable and esthetically attractive setting for the adjacent communities as these develop. However the significance of this situation is not in what the basin is now able to provide, but in the fact that this desirable condition will not continue nor will the few local breakdowns in environmental quality be corrected, unless specific planned action is taken now to bring this about. The question is 
whether this river can escape the deterioration of such steams as lower Gwynns Falls and Jones Falls in Baltimore, or the upper Potomac Estuary in the vicinity of Washington.

In the face of encroaching urbanization, the basin is on the verge of being spoiled. The quality of its water and land resources will inevitably deteriorate, unless deliberate forethought and action to maintain and perserve these values is taken in the very near future. If, for example, an increased degree of treatment for sewage is not provided as waste loadings increase, destructive pollution of the streams of the basin will inevitably result. If the banks of the basin's streams are used as an unregulated depository for rubbish and other wastes, both the land and the water will be degraded, with attendant destruction of recreational, esthetic and wildhife values. If park and open space acquisition is not pursued as rapidly as possible, residential and industrial developments will occupy the land at densities which will make prohibitive its acquisition for these purposes.

The imminence of these possibilities and the need for early corrective action has recently been recognized by the officials and legislators of Maryland. It resulted in the 1967 appointment by the Governor of the Patuxent River Watershed Advisory Committee. The Committee, in turn, requested the State Planning Department to review the situation and to develop proposals for ways and means of preventing the deterioration of the basin's values.

The following analysis and recommended action programs growing out of this directive have been developed with the cooperation and assistance of representatives of all affected State departments; the Washington Suburban Sanitary Commission, Maryland-National Capital Park and Planning Commission, Regional Planning Council for the Baltimore area, Metropolitan Washington Council of Governments, Tri-County Council of Southern Maryland, Post Engineers' Office of Fort George G. Meade and Chesapeake Field Station of the Federal Water Pollution Control Administration, constituting a Technical Task Force for the Patuxent River Basin Study. Cooperating with the Technical Task Force were the State and county offices of the United States Soil Conservation Service.

The report presents specific recommendations for immediate action programs, which, if carried out, should result in correcting existing abuses and in preserving the splendid values which this river basin has to offer to the people of Maryland. This is a unique challenge. These recommended programs are proposals for action before urbanization has destroyed the basin's value, rather than after serious disruption in the quality of the enviroment has occurred. 


\section{CHAPTER II}

\section{DESCRIPTION OF THE PATUXENT BASIN}

\section{Physical Characteristics}

The Patuxent River Basin extends in a generally southeasterly and then southerly direction from its origin on Parris Ridge at the junction of Howard, Montgomery, Frederick and Carroll counties to its mouth on the Chesapeake Bay, a distance of about 110 miles. It covers about 930 square miles, or about $91 / 2$ per cent of the land area of the State, and averages approximately ten miles in width. The main stem of the river forms the boundary between Howard, Anne Arundel and Calvert counties on the north and east, and Montgomery, Prince George's, Charles and St. Mary's counties on the south and west. The basin, its political subdivisions, and its relationship to the Baltimore-Washington Metropolitan complex are shown in Figure I.

The basin consists of three distinct physiographic reaches or regions. The upper or headwater region lies in the Piedmont Plateau entirely within Howard and Montgomery counties, and extends from the Frederick County line to the Fall Line at Laurel on the main stem and Savage on the Little Patuxent branch. In this rolling upland region, the valleys are relatively steep-sided with little if any flood plain. Stream flow is relatively swift. Two reservoirs on the main stem now supply 45 to 50 million gallons of water per day to the Maryland portion of the Washington suburban area comprising the Washington Suburban Sanitary District. A general policy of restricting development in the watershed above these reservoirs to low population density by means of zoning regulations is designed to preserve the quality of water in the reservoirs. State and county agencies are now developing extensive public parks along the river and its major tributaries in this portion of the basin. Pollution is not a significant problem because, with the exception of a few small industries and institutions which discharge treated wastes directly to the stream, almost all of the waste waters of the area are either diverted out of the watershed or carried downstream by interceptor sewers to treatment plants located in or near the Coastal Plain. Plans for development in this part of the basin suggest that this policy will be continued.

The middle reach of the basin extends from the Fall Line into the coastal plain approximately to the head of tide at Queen Anne's Bridge and perhaps into the tidal zone almost to Waysons Corner. The upper sixteen or eighteen miles of this reach are characterized by broad, flat, low lying, swampy flood plains on eacl side of the river and its tributaries, and by sluggish flow in the stream itself. The stream proper is relatively narrow (50 to 75 feet in width) and shallow, the banks heavily forested and for the most part inaccessible and still in a wild and primitive condition. It serves as an important wildlife refuge and fish propagation area. It is into this reach of the river and its tributaries that most of the waste water effluents originating in the basin are discharged. Waste water discharges, even after what up to now has been considered good treatment, are causing a progressive downward trend in stream quality due to a gradual reduction in oxygen content in the stream as waste loads increase. This reduced oxygen condition disappears by the time the stream reaches the open estuary. Several sanitary landfills (garbage and rubbish disposal areas) are now operating close to the river in this reach, and several others are planned. Some polution of the steam has resulted from these operations.

The lower third of the basin consists entirely of the tidal estuary. The upper 5 or 6 miles of this reach traverse a relatively narrow valley with firm or high land close to the thread of the stream. Beginning in the vicinity of Spyglass Island two miles above Waysons Corner, however, the stream again enters an area of marsh lands. Here the marshes are not forested and are apparently the result of the silting up of the original estuary. Viewed from the air, and as shown on topographic maps, the broader width of the original estuary is clearly discernible, extending about 14 miles downstream to below Lower Malboro. The river itself meanders as a relatively narrow ribbon of open water through this accumulated silt. Presumably the open estuary in precolonial times must have extended all the way upstream to Spyglass Island and presented then the same broad, open plained appearance in this section that it now does below Deep Landing and Cedarhaven. As in the case of the Patapsco, the Gunpowder and the Anacostia rivers, this siltation is attributable to erosion from the farm lands of the basin over a period of three hundred or more years, and can be expected to continue in the future to the extent that soil erosion from subdivision development, road construction and farming continue.

Below Deep Landing the estuary gradually widens and deepens into a typical saline arm of the Chesapeake Bay. The marshy shores are replaced in 


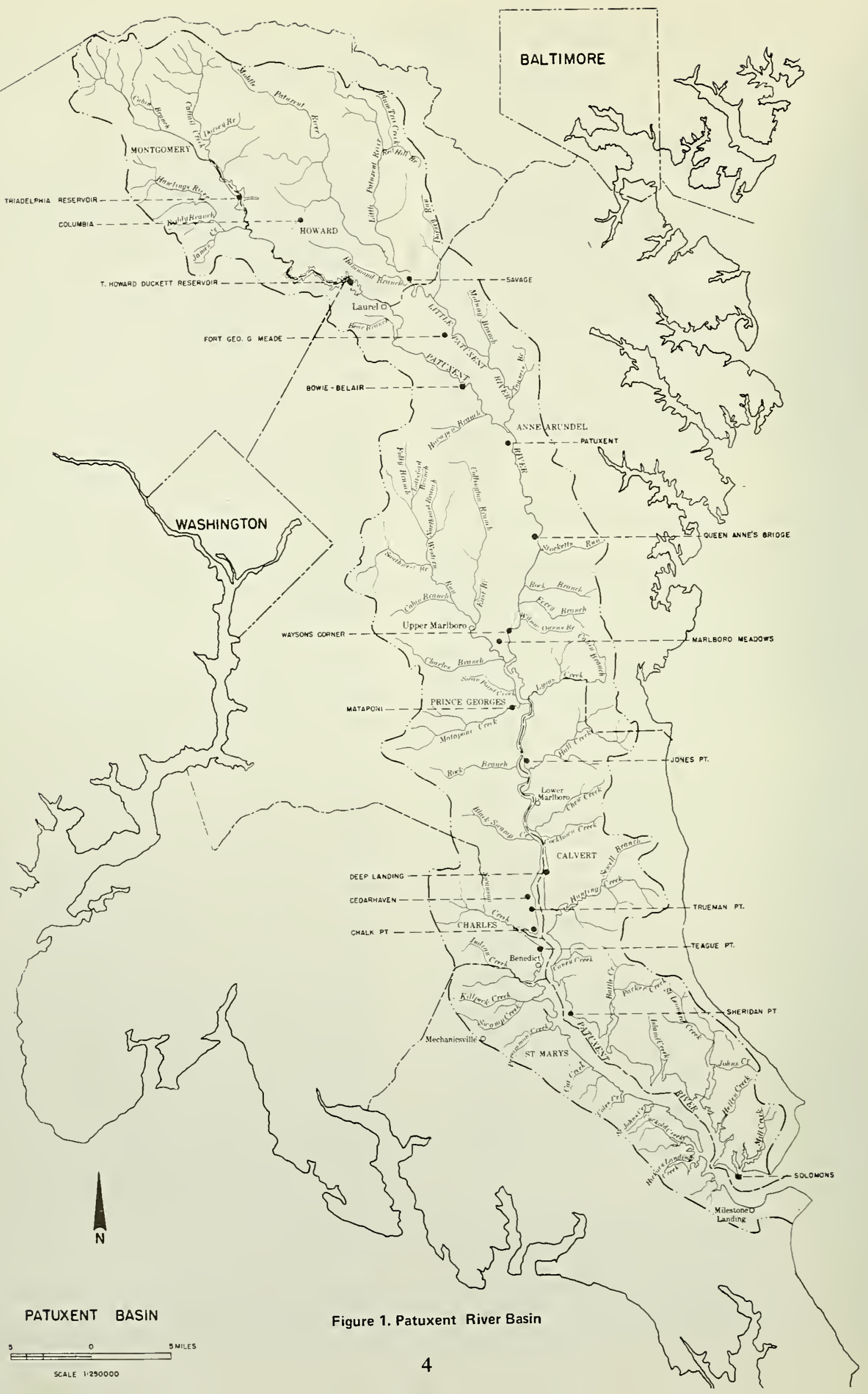


most areas by bluffs, often 20 feet or more in height, with sandy shores and rolling hinterland. Except to the degree that it might be induced at the upper end, oxygen depletion does not generally occur in this reach of the river. However, thermal pollution caused by discharge of cooling water from the steam-electric power plant at Chalk Point is reported to be causing local effects upon aquatic life and the general ecology of the estuary. Bacterial pollution locally has caused restrictions to be placed on oyster harvesting in a small area near Solomons Island.

\section{Culture, Industry and Population of the Basin}

Until comparatively recent times the whole basin was largely agricultural in nature. Laurel, Savage and Guilford, all originally mill towns, were located on the Fall Line to take advantage of the water power available at these sites and remained relatively stable or even declined in population with the advent of electric power and the demise of the mills. A fourth mill town, Triadelphia, on the upper reaches of the main river, at one time held great promise of growth, but was destroyed by a disastrous flood about a century ago. It was located in an area now covered by Triadelphia Reservoir. Other centers of population, such as Bowie and Upper Marlboro in Prince George's County, Burtonsville, Sandy Spring, Brookville and Damascus in Montgomery County, and Clarksville in Howard County, served primarily as distribution and service centers, were relatively small, and remained stable in population. The two mainline railroads, one interurban electric railway, and one highway, all of which ran parallel with the Fall Line and crossed the valley within a few miles of each other to connect Baltimore and Washington, had little effect upon the industry of the basin except for their connections to the mill towns.

The advent and perfection of the automobile enabled people to choose where they would live and the basin's stable, low density agricultural economy began to change. Slowly, at first, people began to push outward from the cities into the basin, most of them commuting to work in the cities. With the end of World War II, however, additional highways were built and this movement became a rush as the great metropolitan explosion of the late 1940's and the 1950's hit the United States. Then came the new towns and extensive suburban type subdivisions and industrial development, as beltways and divided lane higliways freed industry from dependence on the railroad and the need to be immediately adjacent to its labor supply. The movement into the basin was no longer one of creeping in from the sides, but a leap-frogging series of jumps into its very center.

Thus, today, we see developments such as Columbia on the Middle and Little Patuxent branches in central Howard County started from scratch on 14,000 acres of farmland and planned for growth to over 110,000 people by the early 1980's. Laurel, once a sleepy small mill town except during the horse racing season, is now the center of an intensively developing residential, industrial and government agency center which will very likely parallel Columbia in population growth. With the development of the Belair project on the old Woodward estate in Prince George's County, Bowie suddenly was engulfed in similar fashion. Industrial developments along the beltways, railroads and expressways followed.

The upper and middle reaches of the basin are rapidly increasing in population, bringing uprecedented demands upon the basin and its resources for water supply and sewage disposal systems, parks and open spaces, and all the paraphernalia of urban and suburban life. As pressures increase, this spread of people and industry will presently affect the lower counties of the basin also. Table 1 shows the total populations projected for the basin counties, the per cent of county in the Patuxent Basin, and the projected population by county for the Patuxent Basin portion of the county.

\section{Previous and Existing Water and Land Management Activities in the Basin}

In order to meet the increasing demand for water supply services discussed above, the Washington Suburban Sanitary Commission, under a permit granted in 1941, with subsequent amendments, constructed two reservoirs on the main stem of the river and now withdraws 45 to 50 million gallons of water daily for use in the Washington suburban section of Maryland, mostly outside the basin. The permit calls for the WSSC to release water from the Rocky Gorge Reservoir sufficient to maintain a flow of not less than 10.5 million gallons per day (16 cubic feet per second) in the river at Laurel. During the past few years, releases have been substantially less than this amount, averaging only 6 to 8 million gallons per day.* The permit reserves all riparian rights downstream from Rocky Gorge, and also requires payment to the Game and Inland Fish Commission of an annuity in lieu of provision of a fish ladder at the dam.

\footnotetext{
* Release of the full amount called for by the pernit would have helped alleviate the low oxygen conditions which on occasion have developed downstream in the river.
} 
Table 1

\section{County and Patuxent Basin Population Projections*}
County**
$\%$ of Co.
in Basin 1960
1970
1980
2000
2020

Prince George's

Total Population

County Basin Pop. 50

$$
\begin{aligned}
& 357,400 \\
& (48,000)^{* * * *}
\end{aligned}
$$

621,100

770,300
175,600

$1,002,600$

$1,305,000$

Montgomery

Total Population

340,900

County Basin Pop. 10

$(* * *)$

508,000

$\underset{* * *}{630,200}$

870,000
$* * *$

$\underset{* * *}{1,300,000}$

Anne Arundel

Total Population

County Basin Pop. 31

206,600

$(43,400)^{* * * *}$

316,800

415,700

600,000

866,000

$79,700 \quad 105,800 \quad 153,000$

Howard

Total Population

County Basin Pop. 77

36,200

$(1,500)^{* * * *}$

65,300

112,800

73,000

215,000

413,000

$157,000 \cdot 316,000$

Calvert

Total Population

15,800

County Basin Pop. 83

(not significant)

21,900

26,200
10,500

46,200

81,500

$18,500 \quad 32,600$

St. Mary's

Total Population

County Basin Pop. 24

38,900

$(18,000)^{* * * *}$

50,700

60,600

72,000

85,500

35,000

42,000

50,000

Charles

Total Population

32,600

County Basin Pop.

(not significant)

42,600

58,200
2,800

75,300

97,400

3,300

4,000

TOTAL BASIN POPULATION

$(110,900)^{* * * *}$

376,600

634,500

984,100

* Population projections for the Patuxent Basin portion of the counties were developed by the Federal Water Pollution Control Administration for use with their Patuxent water quality analysis model. They do not necessarily reflect the official view of the Regional Planning Council and the Maryland-National Capital Park and Planning Commission.

** 1980 and 2000 county estimates are from Maryland State Planning Department-2020 county estimates are an extrapolation of these estimates.

*** Most of this area will be served by Washington, D.C.'s waste treatment facilities.

**** Estimated current population served by waste treatment facilities discharging to the Patuxent Basin. 
In 1961, at the urging of the Baltimore Regional Planning Council and other agencies in the Washington area, a comprehensive waste water collection and disposal study for the Patuxent River Basin was initiated and financed jointly by the affected counties and other jurisdictions in the Baltimore-Washington region, together with the State Department of Healtl. Dr. Abel Wolman, Dr. John C. Geyer and Mr. Benjamin E. Beavin were engaged to undertake the study.*

The plan developed for the collection and disposal of waste waters originating in the basin provided for disposal almost entirely within the basin. 1 included a series of interceptors together witl treatment plants at Savage, Laurel, Bowie, Patuxent and Mataponi. With the treatment proposed, the study indicated that the streams of the basin could assimilate the projected waste loads up to the year 2000. An alternate plan would have carried all wastes down to Mataponi where a single treatment plant would have treated the wastes before discharge into either the estuary or an outfall to the Chesapeake Bay. This plan was not recommended as it did not readily lend itself to stage construction and because of objections to the temporary nature of the interim upstream plants that would be required. The plan first described above is the one which has been followed by the State Department of Health in consultation with the several counties of the basin as regards the provision of waste water disposal facilities. All of the treatment plants proposed in that plan have been or are being built.

The 1961 waste water disposal study also proposed that the shorelines of the river and its tributaries be purchased by public agencies as a means of protecting the river and preserving the environment. The general idea behind this recommendation was that through public acquisition of the shorelines of the river, urban encroachment, as well as indiscriminate dumping, would be prevented, desirable recreational open spaces associated with adjacent water bodies would be preserved, pollution of the stream prevented and erosion and sedimentation of the stream channels controlled. The Maryland Legislature passed the Patuxent River Watershed Act in 1961 to aid in implementing this proposal. Funds for both this purpose and to aid the State Department of Forests and Parks in acquiring land for the Patuxent State Park on the main stem above Triadelphia have been provided by the Legislature.

Water quality studies and investigations in the basin were undertaken by the Federal Water
Pollution Control Administration in cooperation with the State Departments of Health and Water Resources in 1966 and 1967. These studies included extensive field surveys and measurements and have produced new data on rate of stream flow and re-aeration in the middle reach of the river below Laurel.** The studies now indicate that the middle reach of the Patuxent has a lower waste assimilation capacity than was first indicated by the 1961 waste water disposal study. When combined with upward revisions of projections of population growth and waste water discharges made necessary to take account of unanticipated new town development, such as Columbia and Belair and other extensive subdivision activities, there are indications that, while the degree of treatment presently accorded wastes in the Patuxent would normally be considered adequate, an even greater degree of treatment will soon be required if the instream water quality standards recently adopted by the State are to be met and if damaging degradation of the stream is to be prevented.

In 1966, the Legislature enacted a measure requiring all counties and the City of Baltimore to prepare by 1970 comprehensive programs for provision of water supply and waste water disposal. In addition, a proposal is now under study which would set up a State operated waste acceptance service to handle all liquid wastes in the State.

In 1967 the State, in compliance with the requirements of the Federal Water Pollution Control Act of 1965, as amended, adopted water quality standards for all of the streams of Maryland. These standards designate the uses and activities to be supported and establish the water quality required to be maintained in the several reaches and sections of the Patuxent and its tributaries for these purposes. The quality standards and the water uses they are intended to support are described in more detail in Appendix 1. Basic requirements are that throughout the Patuxent Basin, water shall be of such qualtiy as to permit swimming and support fish and aquatic life. In addition, water quality in the estuary must meet the higher bacterial standard required for commercial shell fish areas. Stream water quality at some places in the middle reach of the basin now falls below these standards at times.

The Maryland office of the Soil Conservation Service, in cooperation with the Soil Conservation Districts of the counties in the basin, is developing soil erosion control programs, including plans for water and silt detention basins at various headwaters locations. None of the proposed detention reservoirs

* Patuxent Regional Sewerage Report, 1961.113 pp.

** Re-aeration is the naturally or artificially stimulated adsorption of oxygen back into the water. 
has yet been built. A program is also actively being pursued in Montgomery County and will soon be adopted in Prince George's, Charles, and Howard counties for control of erosion from construction and subdivision activities.

While there are several existing planning activities in the Patuxent Basin, it should be noted that no over-all plan for the basin as a whole has been developed.

Planning instrumentalities which now have jurisdiction or concern ithin the basin are: county planning departments or commissions in all of the counties; regional planning agencies for the Washington Suburban area (Maryland-National Capital Park and Planning Commission-M-NCPPC); Metropolitan Washington area (Metropolitan Washington Council of Goverments-COG); Metropolitan Baltimore area (Regional Planning Council-RPC); a Metropolitan Sanitary Commission in Howard County; a Department of Public Works in Anne Arundel County: a Sanitary Authority in Charles County; the Washington Suburban Sanitary Commission-WSSC, covering Montgomery and Prince George's counties; and Park Departments in Howard, Charles, and Anne Arundel counties and the Washington Suburban area (M-NCPPC).

In addition, Baltimore City, Baltimore County and the District of Columbia have interests and programs in these areas of public activity which have some relationship to what is done in the basin, and must be considered in any planning program. At the State level, the State Planning Department, the Departments of Forests and Parks, Health, Water Resources, Game and Inland Fish, and Chesapeake Bay Affairs are all directly concerned from a supervisory and regulatory point of view. In addition, a number of other State departments carry on programs which directly affect water or land management within the basin.

The various enactments, programs, agencies and studies described above provide the setting within which the Patuxent Basin's water and land resources must be re-examined.

\section{Problems of the Basin}

Five principal problem areas require attention in planning for the management of the basin's land and water resources. These are:

1. Water supply

2. Waste water disposal

3. Soil erosion and sedimentation

4. Park, watershed and open space management

5. Preservation, enhancement and use of the estuary.
A sixth problem, that of disposal of rubbish and other solid wastes, relates primarily to the use of stream bank and flood plain areas for parks and open spaces, but also is of concern in relation to problems of both stream and environmental quality. It is discussed in connection with the park and open space problem.

All of these problem areas bear an intimate relationship to each other through either their dependence upon or their effect upon the quality of the waters of the river and its tributaries. Water supply, for example, depends upon the availability of water of such quality that, after treatment, it will be suitable for human consumption. But the withdrawal of water from the stream and transport out of the basin for water supply also affects both downstream water quality and water use by reducing the amount of water left flowing in the stream during dry periods.

Waste water disposal has a direct effect upon the quantity and quality of water in the stream and therefore the use of the streams, depending upon the degree of treatment given the wastes before discharge and their volumes in comparison with that of the receiving stream. The problem results from the fact that there is usually nowhere else to dispose of waste waters at any reasonable cost. Waste waters, unlike water supply, are generally carried in gravity systems which must conform to the drainage pattern of the basin, thereby normally confining the wastes to the basin of origin. Pumping the waste waters out of the basin is often more costly and, in most cases, merely transfers the problem of ultimate disposal to another water body. In some cases, of course, this latter solution is entirely feasible and is resorted to for good reason. But often, in addition to costs, it is objected to from a political or social point of view.

Sedimentation caused by erosion from denuded land surfaces affects both the stream and its bordering lands. The sediments gradually fill the channels, reservoirs and estuaries of the basin, cover and smother the bottom life of these water bodies and, during flood stages, often cover adjacent stream banks and flood plains with objectionable or damaging deposits.

Park, watershed and open space programs have an important relationship to the water resources of a basin in several ways. Park and open space lands are dependent for much of their attractiveness and esthetic value upon the environmental character of their surroundings. The presence of a stream or other water body in association with a park or recreational area is an important factor in creating or preserving the attractive environment desired for such areas, provided that the quality of the water itself is 
sufficiently good to be esthetically acceptable. Then, too, the combination of land and water areas is traditionally and inherently looked upon as essential for park and recreational usage. A primary reason for this is that people generally seek a focal point, such as an attractive water body, an overlook or mountain top, an historical site or similar feature for their outings. A stream, a lake, a bay or the ocean side provides this focal point. Preservation of the quality of the water body is therefore essential to the successful creation of an acceptable park and open space system and, conversely, the preservation of open spaces along the stream aids in preserving and enhancing the values of the stream itself, as well as providing access to it for direct recreational usage.

In this latter regard, the problem of solid waste disposal is intimately associated with that of establishing or preserving stream valley park systems, since improper location or operation of sanitary landfills* for disposal of rubbish has a direct detrimental effect upon the quality of both the stream and the adjacent lands. Under proper management, however, sanitary landfills can often be used as a means of reclaiming for park purposes, lands which might otherwise be useless or actually detrimental to the evironment.
Preservation, enhancement and use of the estuary is directly related to the problem of water quality control, since both aquatic life and recreational use of the estuary depend upon the maintenance of acceptable water quality. Maximum use of the adjacent shores for recreational and residential purposes also depends upon the maintenance in the estuary of water of both esthetic and biologic acceptability.

With respect to the manner in which these several problem areas should be approached, only two of the five can be dealt with strictly from a basin point of view. These are waste water disposal and preservation and use of the estuary. While they are importantly interrelated, only the waste water disposal problem is fully basin-wide in its planning implications. As brought out in succeeding discussions, all of the other problems must be looked at from the broader context or framework of the Baltimore-Washington interregional complex.

The five areas of investigation, the considerations to be taken into account and the organizational arragements to be established in dealing with them are discussed in the following chapters.

\footnotetext{
* Sanitary landfill operations consist of compacting the materials to be disposed in layers, by means of heavy machinery, and then covering these materials with several feet of clean earth to seal the fill.
} 


\section{WASTE WATER DISPOSAL AND STREAM QUALITY CONTROL}

Because of its basic importance to all other water and related land resource considerations, waste water disposal and the preservation of high quality water in the streams of the Patuxent Basin is probably the most important of the five problem areas identified as affecting development and use of the basin's resources. Considerable public and private concern has been expressed in recent years regarding this problem and it has received the attention of State, local, regional and Federal agencies in a series of actions extending over a number of years.

Prior to 1958, waste water disposal in the Patuxent Basin was dealt with primarily from an individual county point of view with the State Department of Health acting as the coordinator and providing whatever basin-wide point of view was brought to bear in dealing with individual situations. In 1958, the newly organized Baltimore Regional Planning Council recognized the need for a basin-wide approach and asked the State Department of Health to chair a regional committee appointed to determine how best to accomplish this objective. A Board of Consultants, consisting of Dr. Abel Wolman, Dr. John C. Geyer, and Mr. Benjamin E. Beavin was engaged to undertake a study and to prepare a comprehensive master waste water disposal plan for the basin. The study was undertaken under the joint sponsorship of the State Department of Health; Howard, Anne Arundel, Prince George's and Baltimore counties; the Washington Suburban Sanitary Commission; Fort George G. Meade; Baltimore City; and the District of Columbia, all of whom shared in its cost. The report of the consultants (Patuxent Regional Sewerage Report) was submitted to the sponsoring agencies in 1961.

Two plans for the collection and disposal of waste waters were prepared. One was designed to collect all of the wastes of the basin in a common collector system and conduct them to a single large treatment plant at Mataponi, where the wastes after treatment would be discharged to the estuary or to the proposed District of Columbia outfall to the Chesapeake Bay, if and when this was built. The second plan proposed separate treatment plants at Laurel, Savage, Bowie, Patuxent and Mataponi to handle the wastes of the basin, with discharge of the wastes into the stream at each of these locations.

The latter plan was recommended by the consultants as being more practicable to implement over the 40 year projected period for which the plans were prepared. Projected treatment requirements were based on maintenance of 5 parts per million $(5 \mathrm{ppm})$ of dissolved oxygen in the stream for 95 per cent of the time, until the end of the 40 year period. The dissolved oxygen requirement is the same as that called for in the new State water quality standards, but the duration period in the new standards is based on the low flow occurring for seven days once in ten years. This is considerably more stringent than the earlier establishments.

Waste loads were computed on the basis of projected populations cited in Table 2. The figures include an allowance for Fort Meade and other Federal establishments.

\section{Table 2}

\begin{tabular}{|c|c|c|c|}
\hline \multicolumn{4}{|c|}{$\begin{array}{c}\text { Patuxent Regional } \\
\text { Sewerage Report } \\
\text { Population Projections }\end{array}$} \\
\hline & 1960 & 1980 & 2000 \\
\hline $\begin{array}{l}\text { Baltimore } \\
\text { Washington Region }\end{array}$ & $3,890,000$ & $6,300,0003$ & $8,600,000$ \\
\hline tuxent Basin & 138,000 & 341,000 & 634,000 \\
\hline
\end{tabular}

The basin's streams and the estuary were indicated to be capable of assimilating the waste loads involved until the year 2000, after treatment to remove 92 per cent of the oxygen demanding organic wastes (biochemical oxygen demand, or BOD) at the Savage plant, and 90 per cent at the other four plants. The plan provided for elimination of the waste treatment plants at Fort Meade and the transportation of these wastes to the Patuxent plant just below the confluence of the Patuxent and Little Patuxent Rivers.

While this recommended plan was not officially adopted, it has since been used by the State Department of Health as a guide in dealing with the respective counties and institutions of the basin regarding the disposal of their wastes. Today, plants have been or are being constructed essentially at the locations proposed for the five plants recommended. However, Fort Meade and a number of other smaller institutions and localities have not yet been connected to these major facilities, but continue to discharge their wastes after treatment into the basin's streams.

Waste discharge points are almost all located in or near the upper coastal plain area above the head of 
tide. All together, waste waters are discharged to the basin's streams at 60 specific locations. The 26 major discharges are listed in Table 3.

In addition to these specific intentional discharges, seepage and run-off from a poorly operated rubbish dump located along the edge of the river in the Bowie-Belair area was recently observed to be discharging a heavy BOD load to the river. This condition is now thought to be corrected, but its occurrence during the course of this study has reemphasized the need for awareness of the general problem of solid waste disposal.*

Following completion of the 1961 master waste water disposal plan, stream sampling surveys were undertaken by the State Departments of Health and Water Resources and the Natural Resources Institute of the University of Maryland. In 1966, the Chesapeake Field Station of the Federal Water Pollution Control Administration (FWPCA), as part of a comprehensive program for water pollution control of the entire Chesapeake Bay system, initiated a more detailed study of the Patuxent Basin, in cooperation with the State Departments of Health and Water Resources. This study was confined largely to that portion of the basin which is identified herein as the middle reach and into which most of the treated wastes are discharged, although some consideration was also given to waste discharges in the Piedmont Region and to evaluation of water quality in the estuary.

The FWPCA in studying the middle reach utilized data accumulated by the several State agencies cited above and also that from FWPCA surveys with respect to time of travel or velocity in relation to volume of flow in the streams of the area. Other investigations covered rate of re-aeration; oxygen, phosphorus and nitrogen content; and other factors which affect waste assimilative capacity and stream biology. Dye studies were used to determine time of travel. A mathematical model was developed for use in predicting effects upon the stream of various levels of waste loading under various stream flow conditions. Details of the techniques and procedures involved in these surveys and studies are set forth in more detail in Appendix 11.

Special attention is called to the fact that the studies to date by the FWPCA did not cover the upper estuary and therefore do not include an evaluation of the effects upon the estuary of treated waste discharges from the Western Branch treatment plant of the WSSC. This plant will have an initial capacity of about 5 million gallons per day of treated wastes which will be discharged directly to the upper estuary. Effluents from the proposed Marlboro Meadows plant will also be discharged to this part of the estuary. Additional investigation in this portion of the estuary and analysis of a considerable amount of data accumulated over a number of years by the Natural Resources Institute is required in order to more fully understand the effects of these discharges and to determine the degree of treatment required to ensure maintenance of acceptable water quality in the upper estuary. This need is discussed further in Chapter 1VPreservation and Enhancement of the Estuary.

Investigations and analy ses disclose that:

1. There is a general downward trend in the dissolved oxygen content of the streams of the middle portion of the basin, with oxygen levels now approaching the State water quality minimum monthly average requirement of $5 \mathrm{ppm}$ and falling below this level at times in some areas. There is every indication that this downward trend will continue as population in the basin increases, unless deliberate steps are taken to prevent its occurrence.

2. Low oxygen levels were also observed in the upper estuary in the area where Western Branch enters. These are unexplained and require investigation. Ebb and flow of the tide and the effects of decay of large areas of marsh vegetation may be involved, as well as waste discharges into the headwaters of Western Branch.

3. Observations in Dorsey Run disclosed a clearly apparent visual degradation of stream quality below the Maryland House of Correction treatment plant at Jessup. Untreated barnyard and dairy wastes combine with inadequately treated institutional waste flows to produce this condition. Fort George G. Meade takes its water supply from the Little Patuxent below its confluence with Dorsey Run.

4. During the recent drought of 1962 to 1967 with its attendant low stream flow conditions, dissolved oxygen levels were observed at several locations in the middle reach and upper estuary to have fallen as low as one ppm, with reported damage to fish populations. Bass are reported to have practically disappeared from some portions of the middle reach, leaving only rough fish. Destruction or reduction in numbers of fish populations, mostly eggs and

* To correct the situation, the landfill operator used heavier equipment to achieve better compaction of rubbish and drainage trenches were established to prevent standing water accumulation. 
Table 3

Major Municipal and Industrial Waste Water Discharges

Patuxent River Basin

Name

WSSC Water Plant

Maryland City

Laurel-Parkway

Bowie State Teachers College

Bowie Race Track

Bowie-Belair

Doughoregan Manor

Dunloggin

University of Md., Folly Quarter Farm

W. R. Grace Company

Johns Hopkins

$$
\text { Laboratory }
$$

Savage

Maryland and Virginia Milk Products

Laurel Race Track

Maryland House of Correction

Fort Meade No. 1

Fort Meade No. 2

Naval Academy Dairy

Patuxent

Anne Arundel Sand and Gravel

Bi County Sand and Gravel

Annapolis Sand and GraveI

Andrews Air Force Base

Upper Marlboro

PEPCO Chalk Point

Electric Plant

Patuxent Naval Air Station

\begin{abstract}
Employees
or Popula-
tion Served
\end{abstract}

$\begin{aligned} \text { N.A. } & \text { Silt } \\ 5,000 & \text { Sanitary } \\ 21,000 & \text { Sanitary }\end{aligned}$

460

Varies

23,000

52

600

21

350

2,000

1,500

45

Varies

2,500

I4,000

16,000

100

4,400

N.A.

N.A.

N.A.

N.A.

700

N.A.

17,500
Waste

Type

Sanitary

Sanitary

Sanitary

Sanitary \&

Industrial

Sanitary

Sanitary \&

Industrial

Sanitary \&

Industrial

Sanitary \&

Industrial

Sanitary

Industrial

Sanjtary

Sanitary

Sanitary

Sanitary

Sanitary \&

Industrial

Sanitary

Silt

Silt

Silt

Sanitary \& Industrial

0.018

0.113

0.150

Varies

0.600

1.200

0.900

0.100

0.700

0.140

0.360

0.384

0.300

Sanitary

0.060

Thermal

720.000

Sanitary
1.400
Type of

Treatment

Lagoon

Secondary

Secondary

Tertiary

Intermediate

Tertiary

Secondary

Secondary

Secondary

Secondary

M. Patuxent R.

M. Patuxent R.

Secondary

M. Patuxent R.

Secondary

L. Patuxent R.

Secondary

Hammond Br.

Secondary

Hammond Br.

Secondary

Dorsey Run

Secondary

L. Patuxent R.

Secondary

L. Patuxent R.

Primary

Towsers Run

Secondary

L. Patuxent

Lagoon

L. Patuxent R.

Lagoon

Patuxent R.

Lagoon

Patuxent R.

Secondary

Trib. Cabin Run

Intermediate

Western Br.

N.A.

Patuxent Estuary

Primary

Pine Run 
young fry, in the spawning areas of the upper fresh water portion of tidal reach are also reported, indicating harmful elfects upon the whole food chain of the estuary, Bay, and nearby coastal waters of the ocean.

5. Current population projections which give consideration to previously unanticipated growth factors, such as Columbia, Belair and other large subdivision developments, indicate a future population for the basin substantially greater than that on which the earlier studies were based. They indicate a threefold population increase between 1960 and 1980 and an eightfold increase in waste water discharges because of the greater proportion of the population which will be connected to sewer systems with increasing urbanization.*

6. The time of travel of water in the critical middle reach section of the river, as disclosed by the dye studies, was found to be much less than that assumed in the earlier studies. In other words, the stream is more sluggish than was earlier thought to be the case.

- 7. The rate of re-aeration of the water in the middle reach area under these sluggish conditions is substantially less than was earlier assumed. In other words, the stream does not recover its lost oxygen as rapidly as was supposed.

8. The probable effects upon the upper estuary of discharges from the Western Branch treatment plant now being constructed by the WSSC near the confluence of this stream with the upper estuary and the proposed Marlboro Meadows plant have not been studied. A detailed and careful study and analysis, employing mathematical model techniques and biological investigations, is required in order to determine the degree of treatment which will be required at this plant.

All of the factors cited above combine to explain the current decline in water quality in the middle reach and upper estuary portion of the basin and the need for additional facilities and a greater degree of waste treatment and/or other corrective measures, both now and in the future.

As a first step, all existing plants should be brought up to their maximum efficiency in handling current waste loads if they are not now so operated. Furthermore, in granting permits for new subdivision developments, provision of adequate capacity to treat the wastes which will result from such development should be required as one of the conditions for issuing permits. In addition, permits for subdivision and other urban developments now in the process of construction should be suspended, if it is found that adequate facilities for treatment of their wastes after completion and occupancy are not being provided.

Provision should also be made at all existing and future plants for receiving and treating sludges withdrawn from the septic tanks of individual household systems and hauled to the treatment plants for disposal. Rigid enforcement of plumbing codes must also be required to ensure the exclusion of rain water from the sanitary collection system during storms, as a means of preventing the overloading of treatment plants during such periods.

In order to accommodate the increased organic pollution load expected to occur in the near future (up to 1980), the capacity, as well as the efficiency and level of treatment, of existing plants must be increased, and new facilities provided. Based upon a uniform treatment policy for projected 1980 loads, and a minimum monthly average dissolved oxygen content in the stream of 5 ppm during a 7 day, once in 10 year low flow recurrence interval, these plants should be designed to provide 94 and 96 per cent removal of five day BOD for 1980 and 2000 respectively, as compared with 92 and 90 per cent removal under year 1980 and 2000 conditions of loading stipulated in the earlier study. However, attention is again called to the fact that because of inadequate data, determination of the degree of treatment to be required for the Western Branch plant of the WSSC and the Marlboro Meadows plant, both of which will discharge directly into the upper tidal estuary, must await further study.

If a non-uniform rather than a uniform treatment policy is to be followed, one alternative suggested in the FWPCA study and in some commentaries on the Patuxent Basin, difficult

\footnotetext{
* Population projections developed by the Federal Water Pollution Control Administration are shown in Table 1. These projections reflect a more conservative estimation of the rapidity of growth than that suggested by the Regional Planning Council and the Maryland-National Capital Park and Planning Commission. However, the absolute magnitude of the population differences does nol alter the basic findings and recommendations of the Report.
} 
problems of equity between jurisdictions will have to be resolved. The degree of treatment required at any given plant must also be determined in relation to all other plants in the basin by means of systems analysis techniques. The State Departments of Health and Water Resources must jointly work out the several requirements under these conditions and the requirements of the State water quality standards. If the proposed State-wide waste acceptance service is created, the agency administering the program would be the one to resolve this problem.*

In addition to the requirement of a higher degree of treatment, the recent studies indicate that a minimum flow of 20 cubic feet per second (20 cfs) must be maintained at all times in the main stem of the river immediately below Rocky Gorge Dam in order to permit the river to assimilate adequately the wastes discharged to the river after treatment as called for above. This minimum flow could be provided by appropriate releases from the Rocky Gorge Reservoir of the WSSC. Releases from some of the headwater reservoirs proposed by the Soil Conservation Service for construction in the Little and Middle Patuxent sub-basins would also be of limited additional help, but should not be looked upon in any sense as a substitute for releases from the Rocky Gorge Reservoir.

Hydrologic studies by the FWPCA, based upon historical and synthetic hydrologic stream flow data and on 1966 water use data, indicate that releases of $20 \mathrm{cfs}$ from the Rocky Gorge Reservoir could be maintained without interfering with its water supply functions for more than 99.0 per cent of the time. In other words, in only twelve months out of 1,200 months would $10 \mathrm{cfs}$ of dilution water have to be supplied or water supply exports restricted in order to provide adequate assimilation of the waste discharges. It is of interest to note, however, that increasing the volume of the releases to maintain $30 \mathrm{cfs}$ in the stream would make little improvement in water quality in the stream and only a slight reduction in treatment requirements. Additional releases would merely push the critical pollution zones further downstream.

It is suggested that the Department of Water Resources undertake a re-examination of the terms and conditions of the existing WSSC permit to withdraw water from the Patuxent Basin to determine the feasibility of providing the $20 \mathrm{cfs}$ of dilution releases from Rocky Gorge Reservoir called for above, as compared with the smaller releases now provided for in the permit, and the terms and conditions under which they should be provided. This agency, in cooperation with the Soil Conservation Service, should also explore the possibility of providing for some release of water for assimilation purposes from some of the headwater dams proposed for flood control, even though these would be of only small benefit. The Department should also investigate this possibility in connection with the granting of a permit to the Howard Research and Development Corporation for construction on the Middle Patuxent of Lake No. 5 in the new town of Columbia.

Treatment at all plants will also require continuous disinfection to reduce bacterial pollution sufficiently to conform with the new State water quality standards.

Beyond 1980, more permanent solutions to the waste water disposal problem must be found, such as diversion to the lower estuary or even out of the basin, additional treatment, merchanical re-aeration, complete waste water renovation or a combination of these methods. ${ }^{*}$ The degree of treatment and dilution or other solutions to be applied to these future loadings beyond 1980 will require further detailed study and analysis, as indicated in succeeding pages.

In addition to causing damaging decreases in the dissolved oxygen level, domestic and similar waste water discharges contain phosphorus and nitrogen which have other serious degrading effects upon the receiving stream. Phosphorus and nitrogen are important plant fertilizers. Of these two elements, phosphorus is the more easily treated, but is not necessarily the most improtant. When nutrients reach a critical level in a lake or estuary where the flow is not sufficient to prevent a concentration, massive and extensive algal blooms and other aquative plant growth may be stimulated. These are not only objectionable esthetically, but create nuisance conditions and secondary oxygen depletion when they die and decay. Fish kills and destruction of aquatic life, as well as odors and disagreeable visual effects then result. Reduction of phosphorus in waste discharges can usually prevent algal blooms. For this purpose advanced treatment following conventional secondary treatment is required.

\footnotetext{
* A Program for Water Pollution Control in Maryland." February 1967. Commission to Investigate the Problems of Water Pollution Control.

** Complete waste water renovation is indicated by recent studies of the FWPCA to be entirely feasible, technically, and may eventually prove to be an acceptable solution.
} 
The various alternative waste treatment systems for the Patuxent Basin are discussed and costed out in the FWPCA Patuxent River Basin comprehensive water quality program-Appendix 1I.

No detailed analysis of the estuarine portion of the Patuxent has yet been made, although considerable data have been accumulated. Such an analysis is badly needed. However, preliminary analysis of water quality in the upper estuary by the FWPCA suggests that the phosphorus contents of this reach, while not yet critical, is very nearly so and that it might take only a little additional phosphorus to trigger an objectionable algal bloom condition similar to that which now occurs each summer in the upper Potomac Estuary. Reports by Stottlemeyer and Stross in 1964 and 1965 suggest that this condition has already been reached and only the turbidity in the water, which excludes sunlight and thus reduces photosynthetic activity, is preventing an algal bloom from occurring now. ${ }^{*} \ln$ any case, the situation suggests that in addition to the treatment facilities required to remove oxygen consuming wastes described above, advanced treatment for removal of phosphorus and perhaps nitrogen may soon be required at most, if not all, treatment plants in the basin if occurrence of an algal bloom problem is to be prevented. More detailed and intensive analysis will be required to substantiate this possibility, but the various local goverments of the basin should begin now to anticipate the possibility that advanced treatment will be needed in the near future and to make provision for it in the layout and the space provisions at their waste treatment plants.

The costs of any required advanced treatment for phosphorus removal would be in addition to conventional secondary treatment. The additional expenditure required has not yet been estimated for the Patuxent Basin, but rough estimates indicate unit costs of about 4 to 5 cents per thousand gallons of secondary effluent treated. This is based on reprocessing the settled sludges to recover lime. For comparison, conventional secondary treatment costs per thousand gallons are 20 to 25 cents.

If treatment to remove nitrogen or other elements were also required, additional expenditures would be incurred. Costs for nitrogen removal amount to 2 cents per thousand gallons and complete renovation 25 cents per thousand gallons. More data on these advanced waste treatment possibilities and costs are presented in Appendix 11.

Planning of the facilities described above is prescribed in the State requirement under S.B. 335 that each county prepare a comprehensive water supply and waste water disposal plan and program by 1970 . In a basin such as the Patuxent, these plans should be prepared cooperatively by the jurisdictions involved for maximum efficiency and minimum cost. Also to be considered is the possibility that a State-wide waste acceptance service may be established, again requiring cooperative planning of basin-wide facilities for most efficient service.

The relationship of the basin program to programs in adjacent jurisdiction of the Baltimore and Washington metropolitan areas must be explored, especially where diversions of wastes into or out of the basin for treatment and disposal appear desirable. Again, alternative methods of treatment or disposal should be explored, such as mechanical re-aeration, complete waste water renovation, injection of treated wastes into the ground, land spreading and diversion to the Bay or Ocean, with exploration of attendant effects upon the ecology of the estuary and the Bay. Establishment of a stream monitoring program will also be required in order that the quality of water in the stream may be kept under surveillance and basin facilities operated accordingly.

From all of the foregoing it is clearly apparent that a new, coordinated and integrated basin-wide plan is required for the disposal of waste waters, both for the immediate future and the longer range. Such a plan would help to provide the data required by the several counties in preparing their comprehensive plans under S.B. 335. Another important reason for undertaking the preparation of a comprehensive basin-wide program cooperatively is that the FWPCA adds a 10 per cent premium to its construction grant offers for treatment plans which are part of such a comprehensive basin or regional program.

For the longer range program beyond 1980, however, the following specific investigations and special studies are required to provide essential data:

* Stottlemeryer, J.R., 1964. "Plant Nutrients and Primary Production in the Patuxent River Estuary." University of Maryland M.S. Thesis.

Stross, R.G. and J.R. Stottlemeyer, 1965. "Primary Production in the Patuxent River." Chesapeake Science, 6:125-140. 
1. Extent and long-term effect of thermal pollution from PEPCO's Chalk Point generating plant on aquatic life in the Patuxent Estuary.

2. Current nutrient levels and degree of removal required.

3. Effect of the effluents from the proposed treatment plant on the Patuxent Estuary.

4. Feasibility and cost of low flow augmentation releases from the reservoirs.

5. Biological and ecological characteristics of the middle reach of the river (marshland area from Laurel to head to tide) as a basis for evaluating the fish and wildlife resources of this reach, their place in the food chain of the estuary and Bay, and the water quality required in the stream.

6. Effects of the wetlands on chemical composition of the river and estuary.

7. Effects of landfills (solid waste disposal) on this reach.

8. Chemical characteristics of the reach with special reference to the effects of nutrients on both this section of the river and the estuary, effects of location of discharge points, and the effect of reduction in turbidity on density of algal blooms and growths also require investigation.
9. Determination of BOD assimilative capacity to establish the required degree of treatment of the waste waters and the effects of impoundments, diversions out of and into the basin, and future increases in flow due to water supply from outside the basin.

10. Re-confirmation of requirements for waste water treatment and water releases from Rocky Gorge or other reservoirs.

11. Effects of gravel washing in terms of turbidity produced and means of eliminating this form of pollution.

12. Effects of non-point sources of pollution such as storm water, street salt, farm and animal wastes and their present and future magnitude.

Several of the investigations called for above are underway or are included in a study program of the estuary which the Natural Resources Institute of the University of Maryland is proposing to undertake, and which is described in more detail in the following section dealing with the estuary. The FWPCA is also planning to extend its studies downstream into the estuary to include some of these items.

Organizational arrangements for implementing the foregoing recommendations for a new basin-wide approach to waste water disposal in the Patuxent Basin are described in a later section. 


\section{CHAPTER IV}

\section{PRESERVATION AND ENHANCEMENT OF THE ESTUARY}

The estuary of the Patuxent presents a special problem of great importance to Maryland. While the estuary is affected by what goes on upstream in the basin, it must nevertheless be examined as a separate problem in its own right.

The upper 14 or 15 miles of this estuary has silted up over the past 300 years. Local bacterial pollution has caused restrictions to be placed on harvesting of oysters from a 5 acre bar near Solomons. Heat from cooling water discharged from the Chalk Point steam electric plant is reported to have detrimental effects locally upon aquatic life, and metals dissolved in the cooling water are suspected of having some deleterious effects upon oysters. Nutrients brought to the upper estuary by the inflowing stream, when added to the already relatively high background phosphorus content of the Bay system, have raised the concentration of phospliorus in this part of the estuary to the point where excessive algae growths are believed to be incipient.

Low dissolved oxygen levels have been observed in the vicinity of the mouth of Western Branch, but have not yet been explained. Sediments continue to be brought to the head of the estuary by the flowing stream, with consquent steady downstream progression of the accumulated silt bed. This buildup also has the effect of progessively pushing the salt water-fresh water interface steadily downstream over time. Also, turbidity caused-by gravel mining and washing in the vicinity of the upper estuary has detrimental effects on the biota.

In spite of the pollutional effects just described, the estuary has generally not yet been spoiled for its traditional uses. It provides both a sport and commercial fishery with the latter use believed to be susceptible of considerable enhancement through planned management.* The environment of the estuary continues at its traditionally high esthetic level, offering important recreational values both on the water and along its shores.

The upper portion of the estuary contains only fresh or very slightly brackish water. This portion of the estuary, together with that portion of the flowing river immediately upstream from it, apparently provides an important spawning ground for rockfish and other species and is, therefore, an important link in the whole seafood chain of the Bay and adjacent coastal waters. The wetlands of this section are an important part of the wildlife habitat of the basin and are believed to have some beneficial influence on nutrient levels. They contribute to the natural food chain of the basin.

The lower, salt water portion of the estuary is, of course, an important source of oysters, clams, crabs and finfish, as well as an outstanding recreational and boating resource. The shore lines are still unspoiled. Numerous waterfront cottage and recreational developments are located in this area. The town of Solomons, at the lower end, is the site of several government activities as well as a marketing and service center for the area.

The estuary's many excellent values could be seriously disrupted by pollution, especially that which would result from over-fertilization and consequent extensive algae blooms, similar to those now occurring in the upper Potomac River estuary. lndiscriminate increased industrial use of the estuary as a cooling medium could damage aquatic life. As intensive subdivision and other construction activities increase in the watershed, massive increases in erosion could also seriously affect, and eventually fill up, a substantial additional section of the upper estuary.

The oxygen balance as well as the nutrient balance could also be seriously affected by effluents from the Western Branch and the proposed Marlboro Meadows treatment plants which will discharge directly into the upper portion of the estuary. These possible effects were not included in the studies of the FWPCA. It will be necessary to include them in the studies of the estuary proposed below in order to determine the degree of waste treatment required at these plants.

Little detailed attention has yet been given to the above problems. Considerable data have been collected through various studies and surveys in the past, but have not yet been analyzed or coordinated. Much additional study and investigation is required to understand the intricate biological complex of the estuary and the Bay and the possible effects of nutrients, heat, reduced oxygen, silt and other pollutional factors on it.**

\footnotetext{
*Appendix IV-Fishery Resources of the Patuxent River System.

** A more detailed technical discussion of the enviromental conditions of the estuary is presented in Appendix III prepared by Dr. Joseph A. Mihursky of the Natural Resources Institute.
} 
The Chesapeake Biological Laboratory of the University of Maryland's Natural Resources Institute is planning a three year study of some of these aspects of the estuary with the aid of a Federal grant. The study will give principal attention to:

1. The effects of thermal loadings on primary production and phyto-plankton standing crops (the basic microscopic organisms upon which the whole marine food chain rests).

2. The effect of nutrients on these same foundation crops.

3. The role of marshes in utilizing nutrient input to the estuarine system.

The proposed study is of limited scope, however, and will not provide all of the data needed to determine what must be done to fully preserve the estuary and its resources.

The following additional studies and investigations are required in order to determine what must be done to prevent the incipient damages to the estuary and its aquatic life from occurring. Depending upon the result of these studies, modification of existing and future waste treatment and disposal facilities and other measures can be planned to accomplish these goals.

1. Biological and ecological study of the estuary with emphasis on possible effects of pollution on aquatic life in general, as well as effects of variations of the inputs of fresh water resulting from alternative water supply and waste water management schemes.

2. Evaluation of the economics of sport and commercial fisling and other seafood resources and of the recreational uses of the estuary.

3. Evaluation of the importance of the estuary to the food chain of the marine resources of the Bay and Ocean.
4. Investigation of the chemical and physical characteristics of the estuary, to determine existing concentrations of nutrients and possibilities of acceleration of existing eutrophication resulting from nutrient build-up caused by waste water discharges, plus effects of reduction in turbidity.

5. Determination of the impact of the Western Branch and other treatment plant discharges on the upper reach of the estuary, in terms of effect upon dissolved oxygen and nutrients, must also be investigated.

6. Evaluation of possible degrading effects of heavy growths of algae upon the estuarine waters and the degree of nutrient reduction required to prevent this from occuring.

7. Investigation of the effects of heat from cooling water on commercial and sport fisheries.

8. Determination of the effect of sediments upon the benthic life of the estuary and upon nutrient cycling resulting from mineral resource extraction, stirring of sediments by tides and boats with powerful motors and normal land run-off into the estuary.

Completion of the foregoing studies within the next several years would provide information needed in planning the long range water quality control program for the basin which must be undertaken after the more inmediately needed waste water treatment facilities have been provided.

Several of these investigations could be undertaken by the FWPCA and the Department of Water Resources in extension of their present work on the Patuxent into the estuarine zone. However, dye studies and mathematical model analyses will not cover all of the items listed above. The organizational arrangements for undertaking these additional investigations is discussed in Chapter VIII-Organizational Arrangements. 


\section{CHAPTER V}

\section{SOIL EROSION AND SEDIMENTATION CONTROL}

Soil erosion during the previous history of the basin has resulted in the sedimentation of fourteen or more miles of the upper estuary and covering the bed of much of the remainder of the estuary with silt to depths varying from 5 to 50 feet. This sedimentation is largely the result of earlier farming practices, especially the growing of tobacco and corn, which required clean cultivation. Farming practices have been greatly improved in the past 30 years and in addition farming in general in the basin has shifted largely to grass farming associated with ljve stock and dairy operations and harvesting of sod. Even where corn is grown, modern methods substantially reduce the amount of sediment produced. As a result, the sediment load from the watershed has currently been reduced to approximately 130 tons per square mile per year in the upper basin and about 235 tons per square mile per year in the coastal plain, with its more easily eroded soils.

With the widespread increase in urbanization and highway construction now taking place in the watershed, especially in the upper four counties, this relatively good condition could change rapidly. Case histories of land undergoing development indicate that erosion from these activities can produce from 1,000 to as much as 120,000 tons of sediments per square mile per year.

In addition, considerable mining and washing of sand and gravel occurs along the banks of the middle reach and the upper estuary. Such activity on occasion produces a certain amount of sediment and turbidity, which is detrimental to the river. This problem should also be dealt with as a part of the concern for the effects of sediments upon the river.

A program is required for the control of erosion from subdivision, highway, and other construction sites and gravel pit operations. It should include restrictions on the amount of land exposed at any one time and on the period of time exposed, as well as requirements for seeding, mulching, paving and other protection, to be applied immediately after grading is completed. Provision for diversion of storm water from denuded areas, the trapping of sediments in temporary detention basins and other measures are also required.

The program should be basin-wide, but the problem is not strictly a basin problem. It is, rather, a county problem since restrictive or control measures will require action on the part of each county, applicable to the entire area of each county. State highway and other inter-county agencies must also cooperate. Federally aided highway programs are now required to include measures for control of erosion during construction by direction of the Bureau of Public Roads, but rigid enforcement of these regulations is required.

Montgomery County has already instituted measures which aim at achieving the desired control of erosion from construction sites. * These regulations require that a plan for erosion control be prepared as a prerequisite for approval of a subdivision plat and a building permit. Howard, Charles and Prince George's counties are drafting similar regulations. Similar measures are required in the other counties of the basin. All of the counties should constantly monitor the results of the application of these measures, once adopted, to determine when or where improvements in either the control practices themselves or in the administrative or legal measures imposed to institute them are required.

A coordinated, basin-wide erosion control program should be developed by the seven counties involved with the joint help of the State Soil Conservation Office, the county soil conservation districts, the Department of Water Resources, and other appropriate State agencies. Recommendations concerning procedures for implementing this proposal are contained in Chapter VI11--Organizational Arrangements. 


\section{WATER SUPPLY REQUIREMENTS}

Domestic water supply within the Patuxent Basin is not, strictly speaking, a basin problem, but must nevertheless be considered in undertaking any study of the area's land and water resources. The basin now supplies water to a large number of people outside its hydrologic limits and will itself need large additional quantities of water for its people in future years. Projections of population growth, based in turn on master land use plans, provide the basis for estimating the volume of this future water supply need.

The water now being withdrawn from the reservoirs on the main stem of the river by the WSSC for use in the Washington Suburban area (largely outside the Patuxent Basin), plus that used by Fort Meade and the House of Correction at Jessup, is probably all that can safely be supplied from surface waters in the basin, since the remainder is required mostly for waste assimilation, preservation of esthetic and environmental factors and for in-stream uses. Furthermore, the remaining reservoir sites and the yields of the basin's streams are both inadequate for the purpose. Thus the Potomac, the Susquehanna and other streams outside the basin must be looked to for any additional surface water supply.

Baltimore now draws water from the Susquehanna River and will probably enlarge its supply from this source in the future. Washington and its suburbs now draw from the Potomac (in addition to the Patuxent for the suburban areas) and must increase withdrawals from this source in the future. Parts of the Patuxent Basin are now supplied with water from both these sources as well as with ground water. Therefore, the provision of additional water within the Patuxent Basin is not strictly a basin problem, but is inextricably bound up with the supply problems of both the Baltimore and Washington Metropolitan regions.

The Regional Planning Council for the Baltimore area, with the aid of a consulting engineering firm, is now undertaking a regional master water supply study designed to provide data for compliance with S.B. 335. The Metropolitan Washington Council of Governments, through its Regional Sanitary Board and with the aid of a board of engineers, currently has under way a similar study for the Washington region.* The first phase of a similar study has recently been completed for Fort George G. Meade.** The WSSC also has plans for additional water supply developments within its own region and a recent study by a consultant for the Maryland Department of Public Improvements recommends that the House of Correction abandon its Dorsey Run supply and secure its water from the WSSC. $* * *$

The four upper counties of the basin now have membership on one of the metropolitan regional planning agencies. In view of all of the foregoing, it appears that the most logical approach to the water supply problems of the Patuxent Basin is through the regional supply and planning agencies of the two metropolitan centers bordering it, together with Fort Meade and the WSSC. This could best be done through immediate coordination of the two regional studies now under way, together with the second phase of the Fort Meade study. It is accordingly recommended that this coordination be implemented immediately by the two regional planning agencies and the Fort Meade Post Engineer. Through this means the information required by the four upper counties for compliance with S.B. 335 can most readily be provided. The State Planning Department should initiate this coordinating effort. (See Editorial note on page 21)

With regard to the water supply requirements of the three lower basin counties, individual county studies may be required. The Tri-County Council for Southern Maryland might also be helpful in providing an overview of this activity. Most, if not all, of the water supply for this area will come from ground water and is therefore largely a local problem to be solved locally, rather than from a basin or regional point of view. An evaluation of

* Metropolitan Washington Council of Governments. Future Water Supply-Metropolitan Washington Region. Report No. 1-Requirements and Sources (1967) has been published.

** U.S. Army Corps of Engineers, Baltimore District Office. 1966. Report on Exploratory Study of Water Supply for Fort George G. Meade, Maryland.

*** Maryland Department of Public Improvements. 1966. Report on Water Supply Improvements at the House of Correction. 
the ground water resources of the tri-county area is now being undertaken by the Maryland and U.S.
Geological Surveys. A study of Charles County alone has been completed.*

\section{Editorial Note}

The Maryland Geological Survey has commented directly on the question of the availability of ground water in the Anne Arundel-Prince George's County area. Because the role of ground water was unintentionally minimized in the Report text, the full statement of the Survey on this matter is cited for reference. It is as follows:

"Regarding water supply in the Anne Arundel-Prince Georges County area, the "Report" implies that ground water sources have already been exploited to the maximum and, therefore, do not constitute a viable alternative. While it is true that ground water sources alone cannot supply thequantities of water necessary to meet future demands in the area, it should be explicitly understood that considerable amounts of ground water remain to be exploited. In Anne Arundel and Prince Georges Counties daily ground water withdrawals total about 30 million gallons. It is estimated, however, that as much as 125 million gallons per day can be pumped from the several aquifers underlying the two counties without exceeding a "safe yield". In order to approach this amount of withdrawal, it would be necessary to develop a system of properly spaced well fields. To date, cases of ground water failure in the Coastal Plain can be traced to ill-conceived attempts to withdraw excessively large amounts of water from geographically restricted areas. The cost and feasibility of establishing linear well fields within the proposed park lands surrounding the river and its tributaries should be considered. The compatibility of this arrangement has been effectively demonstrated by the City of Salisbury. Ground water thus obtained could be used to supply surrounding consumers and, perhaps, for low flow augmentation."

It should be cautioned that, while the ground water reserves are plentiful, they are widely dispersed and should not be viewed as a panacea to all water supply needs.

*Maryland Geological Survey (T.H. Slaughter and E.G. Otton). 1968. Availability of Groundwater in Charles County. Bulletin 30. 


\section{PARK, RECREATIONAL AND OPEN SPACE LAND ACQUISTION NEEDS}

The 1961 report of Messrs. Wolman, Geyer and Beavin recommended that the shore lines of the basin's streams be acquired by appropriate public agencies as a means of preventing erosion and sedimentation, protecting and preserving the quality of the streams and their environs against urban encroachment, indiscrimate dumping, pollution and descration, and providing needed recreational areas and open spaces. The proposal called for public acquisition of bordering lands to the 20 foot contour in the tidal zone of the river, to 20 feet above the water surface in the middle reach up to the Howard County line; and above that point sufficient to provide a stream valley park system of not less than 500 feet in width on the Little and Middle Patuxent rivers, plus broader areas where this seemed appropriate and in accord with the plans of the Howard County Planning Department. The Patuxent Watershed Act of 1961 was enacted by the Legislautre to implement and help finance this recommendation.

In the same year, a study was prepared by a consultant for the State Department of Forests and Parks, entitled "Study for a Proposed Patuxent Valley State Park." The study endorsed a proposal made jointly by the Howard County Planning Department and the Maryland-National Capital Park and Planning Commission that a state park be acquired and developed on the main branch of the Patuxent, from Laurel to its source above Damascus, including the lands below Rocky Gorge Dam through the town of Laurel and along the river between the two reservoirs; together with lands along the Hawlings River, Cattail Creek, and certain tributaries to the reservoirs. The report also pointed out that the WSSC reservoirs and their surrounding lands possessed great recreational values and that the State Department of Forests and Parks should undertake to arrange with the WSSC for the use of these lands and water areas under agreements which would prevent the water supply from becoming polluted. These negotiations have never been initiated, but the potentialities of these resources for recreation should be recognized in any Patuxent Basin park program. The more extensive discussion of this problem and of the recommendations for dealing with it contained in the 1961 report on the Patuxent State Park are, by reference, again made a part of this report, with the recommendation that they be given careful consideration in the planning of the Patuxent Basin park program.
The Patuxent State Park proposal of 1961 was, in general, approved by the Legislature and funds were provided to start acquisition.

In addition to the two programs described above, the M-NCPPC also developed an extensive program of its own which included land acquisition along the Patuxent and its tributaries in Montgomery and Prince George's counties.

These three programs provide an admirable start toward the development of an extensive park system in the Patuxent Basin and are essential for protecting and preserving the existing high quality of the streams involved against gross enviromental deterioration similar to that which has occurred in the lower reaches of the streams flowing through Baltimore City.

However, limiting the acquistion of park and recreational lands to stream valleys places a restriction on the provision of park, recreational and open space lands required to meet the full requirements of modern society. The stream valley lands are not aways suitable for all types of recreation and other outdoor activities, nor are they always suitably located. This does not mean that the stream valley parks are not essential. What is true, however, is that the stream valley parks must be looked upon as part of a larger system of recreational and open space lands that provide for the needs of the whole area. In other words, a park system extends beyond and serves a larger territory than just the basin of the streams involved. Such a system must be planned on a county-wide or region-wide basis, rather than a stream basin basis, to be fully effective.

From this point of view, the provision of park and open space lands in the Patuxent Basin is not simply a basin problem, nor is the need for park and recreational areas within the basin just a problem of the people of the basin. It is, rather, a part of the problem of meeting the needs of the much larger community consisting of two metropolitan centers which border the basin and of which the basin is a part. Furthermore, while the lands to be acquired are often assocaiated with adjacent water resources and are intended to aid in protecting these resources, they are not limited to this criterion alone. Water orientation is only one among several criteria to be considered.

The problem of open space and recreational needs has been the subject of study by the two 
metropolitan regional planning councils, by Howard County, by Montgomery and Prince George's counties through the Maryland-National Capital Park and Planning Commission and by the State Department of Forests and Parks. Park progranıs are included in the master land use plans of the counties cited and acquistitions of park and recreational land is now underway in these counties. Anne Arundel County has recently initiated efforts to acquire land under the provisions of the Patuxent Watershed Act and Charles County has recently established a Department of Parks and Recreation. The Patuxent Watershed Act of 1961 also provides support for park land acquisition in the other counties of the basin.

The State, through separate State appropriations, is also augmenting the state park system by acquisition of land in the upper reaches of the main strem of the river. However, it has eliminated from its program stream-side areas through Laurel and along the Patuxent between the two WSSC reservoirs and along other tributaries recommended in the 1961 report, and which must be included in any programs to protect the amenities of the river. Federal grants are used to augment all of these acquisition programs.

The Patuxent Watershed Act limits acquisitions to certain areas along the banks of the Patuxent and its tributaries. While this is an excellent program, the acquisitions permissible under it do not provide for a fully rounded park and recreational program within the basin. To understand fully what is required to provide such a program a broader approach is needed and other considerations besides stream bank and flood plain protection must be taken into account. All types of recreation and park usage as well as environmental and open space influences must be considered. As indicated above, this involves concern for the park and recreational needs of the entire bi-city metropolitan complex and should be planned accordingly.

Initiation of such a coordinated inter-city regional approach to open space and recreational planning, embracing all appropriate county, State, Federal and regional agencies and programs, including wildlife and conservation, should be instituted immediately. Leadership for initiating this inter-city park and recreation planning effort should probably rest with the State Planning Department. It should be undertaken on a realistic basis, taking into account actual areas suitable for acquistion in relation to needs, costs involved, spread of population and subdivision activity, the cost of money, the effect of inflation on future costs and other factors. *

Another problem that must be given serious consideration in acquiring and managing the lands bordering on the streams of the basin is that of solid waste (garbage and rubbish) disposal. All too often the low lying lands or the steeper sloping banks along a stream are looked upon as useful only as a repository for trash. The result of this attitude is often a complete despoilation of these areas for any further use and the degradation of the surrounding area itself. Pollution of the adjacent stream, such as that which recently occurred at the Bowie-Belair landfill, can also result. Conditions along lower Gwynns Falls, Jones Falls and Herring Run in Baltimore reflect this attitude.

The steep slopes along the main branch of the Patuxent in the Laurel area present a situation where indiscriminate dumping could and probably will take place in the future as the Laurel community grows, unless efforts are made to prevent this through public acquisition of this narrow strip of steep slope along each bank.

The marshes of the middle reach are also areas where sanitary landfills are beginning to encroach and could cause much degradation unless carefully controlled. Several such repositories of solid wastes already exist and others are proposed in the recently issued report to the Metropolitan Washington Council of Governments.** The effects of these proposed landfills require careful evaluation, especially in light of the values these areas possess for wildlife preservation.

Low lying or marshy areas which are judged to be of low value for other purposes can, of course, be reclaimed for park, recreational and other uses through properly managed sanitary landfilling operations, but these must be carefully controlled to prevent pollution of the stream and degradation of the esthetic and environmental values of the surrounding land.

In addition to the over-all general evaluation of park, recreation and open space requirements within the entire Baltimore-Washington metropolitan complex, the following investigations within the Patuxent Basin proper are required in order to provide information essential for the

\footnotetext{
* The long term trend in land values is steadily upward at a rate which is currently doubling the cost of land every 6 or 7 years. And, subdivision development is moving so rapidly that much of the land involved will no longer be available within a few years.

** Metropolitan Washington Council of Governments. 1967. Solid Waste Disposal Study-For the Washington Metropolitan Region.
} 
preparation of this inter-city regional park and open space program.

1. Determination of the needs for and uses of the wetlands of the basin for wildlife enhancement and other conservation measures.

2. Investigation of the potential effects on the streams of the area of solid waste disposal in the adjacent lowlands and the remedial measures required, with emphasis on pollution problems such as now exist along the river in Prince George's County. Also, an investigation of the benefits to be derived from reclaiming for park purposes, by properly controlled sanitary landfilling, low-lying lands which might otherwise be considered useless.
3. Determination of the needs for flood plain zoning and protection from both freshet and hurricane tide floods under the recently adopted legislation defining lands below the $50-y$ ear flood frequency line as a part of the waters of the State and within the jurisdiction of the Department of Water Resources.

4. Investigation of shore and bank erosion problems and protection needs.

5. Evaluation of the potential uses of the existing water supply reservoirs surrounding lands for recreation and arrangements necessary to protect the quality of the water for water supply purposes. ${ }^{*}$

A more detailed discussion of recommended procedures for initiating the cooperative open space planning program proposed above is presented in Chapter VIII-Organizational Arrangements.

* Needs for open spaces and park and recreation lands per se should be developed through the coordinated efforts of the county and State park and planning agencies. The evaluation of the reservoirs for recreational uses should be part of this over-all open space program, but should also be coordinated with investigations proposed under the regional water supply planning program. 


\section{General Considerations}

The findings and recommendations disclosed by the previously recited investigations into the problems of the Patuxent Basin establish a basis for initiating actions to preserve water and land resources in the face of encroaching urbanization. They would be meaningless, however, unless a concerted effort is made by all affected jurisdictions to implement them.

These findings and the accompanying recommendations are not in themselves final answers. They must be translated into hardware, schedules, budgets and personnel. For instance, this calls for a re-examination of the existing waste water disposal system of the basin. Decisions must be made as to whether existing plants should be expanded to provide the stepped up treatment, their loads limited or reduced or whether these plants should be expanded to take care of anticipated additional waste loads or new plants built at new locations. Consolidation of treatment, for example, abandoning the Fort Meade plants and piping their wastes to the Patuxent treatment plant or other plants must be considered. Planning the additional collection systems will in turn depend upon these decisions. In short, a new master waste water collection and disposal plan for the basin should be prepared as a basis for scheduling the construction of facilities to take care of waste loads up to 1980.

Additional investigation, planning, designing or scheduling of works is required before implementation in terms of actual construction of works, acquisition of lands or imposition of regulations can take place. Because of the multi-jurisdictional nature of the problems to be dealt with, these additional activities should, for maximum effectiveness, be undertaken on a joint or cooperative basis. This need in turn poses the question of how this joint action can best be achieved.

Proposals have been made from time to time that the most effective means of achieving basinwide planning and action would be to create a legislatively established Patuxent Basin Commission composed of representatives from the seven counties whose territories include some part of the basin. This Commission would, under the proposals made, have actual authority to regulate land uses, acquire land, finance, construct and operate sanitary and other facilities, and take on various other responsibilities, all of which now repose in the respective counties having jurisdiction within the basin.
The argument for this proposal is that only by creating such an authoritarian super-agency can the desired objectives described herein be achieved. This is based on the assumption that voluntary cooperative action between the respective counties under the guidance and with the help of appropriate State and Federal agencies would be ineffective or unachievable.

Such an approach to the solution of the Patuxent Basin's problems is believed to be unnecessary and undersirable for several reasons. First, assignment to a basin commission of powers now vested in the counties, with respect to that part of their territory lying in the Patuxent Basin, would in effect fragment the counties' operation by leaving them with remnants of their former territories over which they would still have to exercise all of these functions. Such fragmentation would be inefficient and costly inasmuch as the counties would not be able to support the expert staff required for the adequate performance of these functions within the areas remaining within their jurisdictions. On these grounds, any authority established should obviously include whole counties within its jurisdiction to avoid such fragmentation. This is not likely to be agreed to in the Patuxent Basin.

Secondly, and more importantly, with the exception of waste water disposal, the problems affecting the basin are broader in scope than just the basin and affect the programs of entire counties or the region in most cases. In the case of waste water disposal where the general nature of a disposal system requires that it be dealt with on a basin basis, alternative disposal arrangements involving diversions out of the basin or joint construction of facilities requires consideration of activities and programs of the whole county or region and not just the basin. Cognizance must therefore be taken of plans for waste water disposal and other water uses in areas adjacent to the basin. Even if a commission were established, it would still be necessary for it to deal with the areas and jurisdictions adjacent to the basin to some extent in planning for the most efficient system. Cooperation in such planning would still be needed.

Finally, the effectiveness of the voluntary cooperative approach has been amply demonstrated. The Metropolitan Washington Council of Governments, a voluntary association of seven 
counties and a number of municipalities in two states and the District of Columbia, now provides effective regional planning for the entire Washington Metropolitan area and through its Sanitary Advisory Board and other similar boards achieves excellent cooperation in planning regional water supply, waste water disposal, solid waste disposal and other programs on a fully regional basis. The Council and its advisory boards, nevertheless, possess no actual authority over the member jurisdictions.

Similarly, the Regional Planning Council is providing the necessary coordination in the planning of similar programs in the Baltinore region. Elsewhere in the country similar regional coordinating organizations are achieving good results without the need for an authoritarian super-government.

Proposed in the following pages are a series of voluntary advisory committees composed of county, State and regional technical representatives, each designed to deal with a particular problem. Also proposed in an over-all coordinating basin council or conmittee composed of elected officials to whom t'iese working technical committees would report and through whom actual implementation of recommended programs would be achieved. Given the will to make it succeed, this system of cooperative committees could effectively plan for and achieve the desired improvement and preservation of the rich environmental values and amenities of the Patuxent River Basin which are the subject and concern of this report and of the Governor's Advisory Committee.

\section{Waste Water Disposal}

An immediate requirement in the Patuxent Basin is that all existing waste water treatment plants be brought up to their maximum level of efficient operation and that provision is made at these plants to receive and treat sludges withdrawn from the septic tanks of individual household waste disposal systems. The State Department of Health should immediately undertake the task of seeing that this is done. Beyond this immediate need, the findings of the various studies and investigations conducted by State and Federal agencies over the past several years indicate that the Patuxent River is trending toward an undesirable polluted condition and that an increase in the level of treatment at existing plants, as well as additional treatment facilities, will be needed in the very near future, that is prior to 1980 .

Indications are that for the longer range period, that is to the year 2000, additional facilities or other alternative solutions to the waste water disposal problem such as diversion to other water bodies or other collection and treatment systems, advanced waste treatment, additional dilution, mechanical re-aeration, complete renovation, disposal in the Bay or some combination of these possibilities may well be required. There is a need for a detailed study of these alternatives on a basin-wide basis to determine the most economical and effective solution.

The findings regarding present needs must be translated into an inmediate program of specific facilities to be constructed, with estimates of costs and a time schedule for their construction, and an indication of the agency or agencies which should build and operate them in each case. The design of this immediate program is needed to permit the several counties to complete their comprehensive programs as required under S.B. 335. In essence, this means that a new master waste water disposal plan for the Patuxent Basin must be prepared reflecting the new parameters disclosed by recent investigations and that longer range studies must be initiated to evaluate the need for additional facilities in the future. This re-examination should be undertaken and financed jointly by all of the affected or interested jurisdictions and agencies, both State and local, in much the same manner as was done for the 1961 study.

Also, the 1961 study proposed, among other things, that a voluntary Patuxent Basin Sanitary Board be created to coordinate the planning and provision of sanitary facilities in the basin on a continuing basis.

A similar board has now operated successfully in the Washington Metropolitan area for over eignt years. With the assistance of consultants and other experts it has prepared the master regional waste water collection and disposal, water supply and solid waste disposal programs which now provide the guidelines within the region for the provision of these facilities by the several member jurisdictions. It continues to provide a forum for the discussion and resolution of mutual problems and provides a clearing house for information on all projects affecting the region. It is the instrumentality that reviews applications of member jurisdictions for construction grants as to conformity with the regional plan, as required by the grantor agencies. The Sanitary Board has been effective in a region where it would be virtually impossible to establish within any foreseeable time an autonomous authoritarian regional agency to perform these functions. 
A similar informal advisory committee-The Patuxent Basin Sanitary Advisory Committee-is again recommended for establishment in the basin as the best and most practical means of coordinating planning and the provision of sanitary facilities in the basin on a continuing basis. A further reason for recommending such an approach for the Patuxent Basin is that the comprehensive basin-wide plan which the committee would prepare provides the basis for the additional grant available from the FWPCA for projects which conform with and are part of such a comprehensive plan.

In addition to coordinating the planning for and provision of waste water disposal facilities, including preparation of a comprehensive basin-wide waste water disposal plan, the functions of the Patuxent Basin Sanitary Advisory Committee should include concern for public water supply and solid waste disposal.

With regard to water supply, the two metropolitan regional planning agencies and Fort Meade are now engaged in preparing comprehensive water supply programs for their areas, and all that is required is for the several consultants, plus representatives of the three agencies, to immediately enter into discussions for the purpose of effecting this coordination. For the long range program of the basin, the Sanitary Advisory Committee should concern itself with this problem on a continuing basis.

With respect to solid waste disposal, a regional study recently completed for the Washington Metropolitan area proposes establishment of several sanitary landfills along the Patuxent River in Prince George's County. Because of the general propensity to view wetlands and other low lying areas as mainly suited for just such use, similar areas within the basin, but in other counties, will no doubt also be proposed for this usage. In view of the highly detrimental effects upon the Patuxent River initially caused by the landfill operation in the Bowie-Belair area before discovery and correction, this problem of possible effects of solid waste disposal on river water quality and on the esthetic, environmental and wildlife values of adjacent lands requires continuing attention. Furthermore, the development and management of such landfill areas should be coordinated with the activities of the Park, Recreation and Open Space Advisory Committee hereinafter proposed, in the interest of preserving to a maximum degree the basin's amenities.

Finally, as the previously recommended studies and investigations in the estuary progress, the resulting findings and recommendations will need to be integrated into the water management program of the basin and must be translated into action programs. The Sanitary Advisory Committee should therefore maintain close contact with these studies and should be prepared to act on any conclusions growing out of them that have a bearing on maintenance of required water qualtiy. For the future, the Committee should also initiate and conduct such additional studies of the estuary as may be needed in cooperation with the Departments of Chesapeake Bay Affairs and Game and Inland Fish and the Natural Resources Institute.

Responsibility for water resources management and waste water disposal in Maryland is shared between two State agencies. The State Department of Water Resources has general supervision over withdrawals of water from the streams, for enforcement of the recently adopted water quality standards, and for supervision over disposal of industrial wastes. The State Department of Health has general supervision over disposal of domestic and municipal wastes and is responsible for administering S.B. 335 which requires the counties of the State to prepare comprehensive water supply and waste water disposal programs by 1970 .

It is imperative, therefore, that these two agencies work closely together in full cooperation, not only in the management of the water resources of the Patuxent Basin, but throughout the State. They should obviously be members of the proposed Patuxent Basin Sanitary Advisory Committee and should be prepared to give it assistance and guidance.

In addition to these two State agencies, the membership of the proposed Sanitary Advisory Committee should include the chief sanitary engineers or equivalent officials of each of the seven counties of the basin plus a representative of the Washington Suburban Sanitary Commission, Maryland-National Capital Park and Planning Commission, the Metropolitan Washington Council of Governments and the Regional Planning Council. These regional planning agencies should provide the necessary liaison and coordination with land use and other planning considerations of the basin which determine and affect the density of land occupancy and, therefore, the waste loads and water supplies to be provided for. Other State and Federal agencies, such as the Federal Water Pollution Control Administration, the Natural Resources Institute, the State Departments of Chesapeake Bay Affairs and Game and Inland Fish, should be invited to participate in the activities of 
the board as their interests or their contributions would appear to warrant.

Because of its basic responsibility for and supervisory authority over disposal of domestic and municipal waste water, which are the major pollution problems in the Patuxent, the Maryland State Department of Health should take the initiative in bringing together the representatives of the agencies and jurisdictions named for the purpose of organizing the Sanitary Advisory Committee and should provide the necessary secretarial staff services.

The State is making an application to the Federal Water Pollution Control Administration for a grant under Section 3c of the Clean Rivers Act of 1966 which would facilitate the work of such a committee. The committee will undoubtedly also require from time to time the services of consultants and other advisors. The financing of these and other services should be provided on some sort of pro rata or sharing basis. Federal and State grants would be of material assistance in providing these services. They are available and should be sought.

The program resulting from the activities of the committee should provide the information essential to the several counties in preparing the comprehensive water supply and waste water disposal programs and schedules called for in S. B. 335. These programs are to be completed by 1970 . The organization of the Sanitary Advisory Committee and initiation of its comprehensive planning and programming studies should therefore be pursued assiduously and undertaken as soon as possible. The committee should, accordingly, be brought into being at the earliest possible moment.

\section{Regional Water Supply Coordination}

As pointed out earlier, the two metropolitan regional planning agencies and Fort Meade are conducting comprehensive regional water supply studies. These studies should be coordinated in the interest of determining the most economical and logical means of supplying water to the peoples of the basin. For this purpose the State Planning Department should take the initiative and immediately call together appropriate representatives of these three agencies and their consultants to insure that this coordination is achieved.

For the longer range program, the Patuxent Basin Sanitary Advisory Committee should assume jurisdiction over basin-wide coordination and planning for water supply facilities as discussed in the preceding section.

\section{Park, Recreational and Open Space Planning and Coordination}

It was indicated earlier that the problem of providing adequate park, recreational and open space lands in the Patuxent Basin involved something more than simply acquiring the lands immediately bordering the streams of the basin. Involved is consideration of activities and programs for which lands other than stream bottom lands may be required. Also involved is the relationship of the basin to two adjacent metropolitan regions and an evalvation of the basin's resources in relation to the total park, recreational and open space requirements of this entire bi-city metropolitan complex. This problem requires, for solution, the coordinated and cooperative attention of all park and planning agencies in the entire Baltimore-Washington metropolitan region on a continuing basis. The possible additional use of the two reservoirs of the WSSC and the lands surrounding and lying between them, in relation to the other recreational lands of the basin and region, must also be integrated into the total planning effort.

It is recommended that the Maryland State Planning Department assume the responsibility for organizing a Baltimore-Washington Metropolitan Park, Recreational and Open Space Advisory Committee to deal with this task on a continuing basis. The committee should include in its membership representatives from all of the seven county planning commissions or departments, the MarylandNational Capital Park and Planning Commission, the Washington and Baltimore regional planning agencies, the respective park boards or departments in Howard, Anne Arundel and Charles counties (and other counties as park agencies are created within them), the Washington Suburban Sanitary Commission, the State Departments of Forests and Parks, Chesapeake Bay Affairs and Game and Inland Fish.

The Committee should, as soon as possible, undertake a detailed, definitive study covering at least the next 40 years of the park, recreation and open space needs of the bi-city region in relation to projected populations, income, leisure time and other factors affecting outdoor activities. Careful attention should also be given to the wildlife conservation values of the wetlands of the upper coastal plain and the need for their preservation, and the problem of how to manage WSSC reservoir lands for additional recreational usage in relation to their primary functions as public water supply facilities. 
The problem of the unequal financial resources of the several counties of the basin for the purchase of park lands, as indicated by populations varying from a mere 20,000 in Calvert County to about 500,000 in Prince George's County, should be given serious attention in an effort to devise some method of equalizing the burden of providing a truly regional approach to park development.

The relationship of the Baltimore-Washington regional park, recreational and open space requirements to the state-wide park plan and program of Maryland slould also be determined.

In considering the basin's public land needs, the Committee should also give careful attention to the problem of solid waste disposal. So called waste lands in marshy or other low lying areas or in worked-out gravel pits or other areas can often serve as excellent sites for sanitary landfills, with useful park land as the end product. Mismanaged or improperly located waste disposal areas, on the other hand, cannot only destroy the adjacent streams biologically and esthetically, but can cast an irreparable blight on adjacent lands. The Committee should accordingly establish a close working relationship with the Sanitary Advisory Committee previously proposed.

The Committee should seek the assistance of the respective planning agencies of the basin, of professional park and recreational planners, environmental and landscape specialist and other experts as needed in determining the patterns of needs, acquisition and management of recreational and other open space lands. The financing of such studies should be shared by all jurisdictions and Federal and State grants should be sought to aid in these efforts.

\section{Erosion and Sedimentation Control}

The need for control of soil erosion and resulting sedimentation was set forth in a preceding section. Montgomery County now requires application of certain practices designed to accomplish this objective as one of the conditions required for approval of subdivision applications and building permits. Howard, Charles and Prince George's counties are preparing similar regulations and expect to adopt them in the near future. The State Roads Commission is now required to include erosion control requirements in its contract specifications on Federal aid highway projects.

For effective control, lowever, such regulations should apply to all public and private construction in all counties throughout the basin. Gravel mining and similar soil disturbing activities should also be included. Better coordination and timing between street and highway grading and installation of utilities to shorten the time of exposure before final paving is required.

It is recommended that the Department of Water Resources assume the leadership in bringing together the appropriate officials of the basin for the purpose of establishing a Patuxent Basin Erosion and Sediment Control Advisory Committee. The Committee would be responsible for devising and/or determining the most effective methods of controlling erosion and reducing sedimentation in the basin and aiding the several counties of the basin in preparing, adopting and enforcing regulations applicable to such measures. The Committee should include the State Soil Conservationist and appropriate representatives of each county oil conservation district and of the Soil Conservation Service office in each county, as well as a representative of the planning, public works, building inspection and/or other appropriate departments of each county. The State Roads Commission should also be represented on this Committee.

\section{Further Investigations in the Estuary}

Little detail is actually known about the behavior of the estuary and its aquatic life in relation to the several kinds of pollution which now threaten it. Much additional investigation is required in order to determine what measures should be adopted for effective control of pollution and for preservation and enhancement of the estuary's values.

The Natural Resources Institute is now preparing to undertake some of the studies required, but these will not cover all of the aspects of the problem which require investigation. The FWPCA is also planning to extend its current investigations in the Patuxent Basin into the tidal zone, but they may not be sufficiently comprehensive to cover all of the aspects of the estuary problem previously cited.

lt is accordingly recommended that the Governor's Office be requested to apply immediately to the Federal Water Pollution Control Administration for technical assistance in undertaking the additional estuarine investigations required. The Departments of Chesapeake Bay Affairs, Water Resources and Game and Inland Fish and the Natural Resources Institute should all participate in these investigations. The findings and recommendations growing out of these investigations should be made available to the Sanitary Advisory Committee as well as the affected State 
agencies and translated into specific action programs. For this reason close liaison between the Sanitary Advisory Committee and the estuary study group should be maintained at all times.

\section{Patuxent Basin Council}

The plans and programs resulting from the activities of the several study groups and technical advisory committees proposed will be meaningless unless they are carried into action. The authority to implement such programs rests, however, with the respective governments of the counties comprising the basin and with the State. This means in effect that this authority rests with the elected representatives of the people: that is, the county comnissioners, council members, legislative delegations and the Governor's Office. They, and they alone, have the power of decision regarding authorization and financing of the works and programs proposed.

In order for these elected officials to be able to make effective decisions regarding the proposals issuing from the several advisory committees they must be familiar with the work of the committees and the circumstances lying behind the proposals made by them. This requires continuous liaison between the elected officials and the advisory committees. It is therefore proposed that a Patuxent Basin Council be created for this purpose. This council should include a representative of the elected governing body of each of the basin counties. It is suggested that it also include a member from the elected delegation representing each county in the Legislature. It is further suggested that the Governor's Office be requested to assume the leadership for organizing the Patuxent Basin Council and be represented on it. The Governor's Office might provide secretarial services.

In selecting the representative on the Patuxent Basin Council from the elected governing body of each county, it is suggested that this representative be the same person who represents the county on the Regional Planning Council, the Metropolitan Washington Council of Governments or the TriCounty Council for Southern Maryland, as the case may be. This procedure is considered desirable because the affairs of the Patuxent Basin bear important relationships to those of the geographical regions within which these three councils function. Coordination between the Patuxent Basin programs and those of the three regional councils is therefore essential for maximum benefits to all. Having the same person represent each county on both the Patuxent and the appropriate regional council would be an effective means of achieving this coordination.

This arrangement has a further advantage in that eventually coordination of governmental activities relating to land use planning, transportation, the provision of public facilities and the management of water and related natural resources in the entire Washington-Baltimore metropolitan complex will require creation of some kind of joint coordinating body. The procedure proposed above could be a first step in this direction.

The Patuxent Basin Council would not possess any independent authority. Its function would be to coordinate. It would receive and review reports and recommendations from the advisory committees. 1t would coordinate budgets for financing the studies and activities of these committees. It would agree upon action programs, budgets and schedules for undertaking programs growing out of committee recommendations and would coordinate the activities of the several counties in undertaking them.

It is suggested that a legislative resolution expressing the feeling of the Legislature that creation of such a council would be desirable and/or a statement from the Governor regarding the desirability of creating such a council might be helpful in securing its establishment. 
Appendix A 



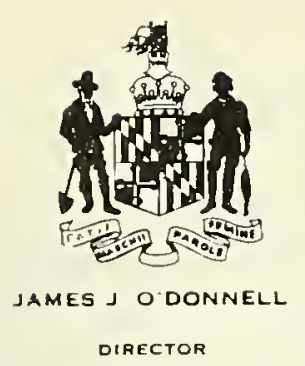

DIRECTOR

\section{PLANNING DEPARTMENT}

STATE OFFICE BUILDING

301 W PRESTON ST.

TELEPHONE: $983-3010$

BALTIMORE. MD 21201

June 4, 1968

Mr. John T. Parran, Jr., Chairman

Governor's Patuxent River Watershed

Advisory Committee

Indian Head, Maryland

Dear Mr. Parran:

I am pleased to transmit herewith the Report on a Re-examination of the Water and Related Land Resource Problems of the Patuxent River Basin-February 14, 1968 prepared for the Maryland State Planning Department in response to the request of the Governor's Patuxent River Watershed Advisory Committee.

In addition to the above mentioned Report, we enclose for consideration of the Advisory Committee an analysis of the Patuxent Study Program by the State Planning Department. This document provides a historical record of the Patuxent Study Program and a broader perspective on the nature of the activity and recommendations made.

The State Planning Department is in full accord with the recommendations contained in the Report as modified. However, the text of the Report, in our opinion, does not deal adequately with the questions of population impact and ground water. We call your attention to the following in this regard:

1) Population changes alone are not responsible for the new indications of a critical waste water control problem in the Patuxent Watershed. Other factors such as percent of population sewered and better defined Patuxent River waste assimilation characteristics have contributed to the finding that the Patuxent River system does not have the capacity to handle waste loads at present levels of treatment and stream flow for even the most conservative populations suggested in 1980 and 2000.

2) Regulated well-fields can play an important role in supplying water to the middle reach of the basin, particularly the Fort George G. Meade and Anne Arundel County areas and should be considered along with traditional surface water supply sources.

We respectfully suggest that the Governor's Patuxent River Watershed Advisory Committee adopt the Report recommendations and give special consideration to the recommendations outlined and modified below.

1) The Department of Water Resources and State Department of Health should investigate with the Washington Suburban Sanitary Commission the possibility of trade-off between higher treatment requirements and increased flow releases from the WSSC reservoirs.

2) The State Department of Health should review and enforce subdivision permits to ensure compliance with waste treatment recommendations and water quality standards for the Patuxent Basin. Permits should be suspended where found at variance with the best interests of ensuring good water quality until such time as provisions are made to provide the level of treatment required.

The framework water quality plan for the Patuxent Basin to be prepared under the provision of Chapter 446 (1968) - Maryland Statute should be used to integrate the county sewer and water facilities plans being prepared under the provisions of S.B. 335 and the technical information on 
waste treatment alternatives being developed by the Federal Water Pollution Control Administration.

The State Departments of Health and Water Resources should withhold approval of any county water and sewer facilities plan not in conformance with the water quality management recommendations adopted by the Governor's Advisory Committee.

3) The Department of Water Resources, in cooperation with the State Department of Health, should be responsible for organizing the recommended Patuxent Basin Sanitary Advisory Committee. In addition to the recommended membership, Fort George G. Meade should be included on the Advisory Committee.

4) It does not appear necessary at this time for the Governor to request additional technical assistance from the FWPCA in studying the Patuxent Estuary. However, it is strongly recommended that the Department of Water Resources develop a formal working relationship with the Cheapeake Bay Institute of the Johns Hopkins University, Chesapeake Biological Laboratory of the Natural Resources Institute, Federal Water Pollution Control Administration, and the Departments of Cheaspeake Bay Affairs and Game and Inland Fish in the course of developing the Patuxent Estuary model. Such a grouping could be constituted as a subcommittee of the proposed Sanitary Advisory Committee.

5) It is strongly recommended that the Department of Water Resources formally approach the basin counties and with the cooperation of the Soil Conservation Service, State Roads Commission and Department of Chesapeake Bay Affairs encourage and assist in the preparation, execution and enforcement of sediment control programs.

6) It is recommended that the consultants and agencies involved in planning for future water supply in the Baltimore-Washington metropolitan area extend their discussions to include the Maryland Geological Survey, role of ground water and the water supply role played by the Maryland House of Correction and State Department of Public Improvements. Furthermore, it is recommended that the State Planning Department inform the Regional Planning Council (Baltimore), Metropolitan Washington Council of Governments, Fort George G. Meade, and the Maryland Department of Public Improvements of these recommendations.

7) It is recommended that a Baltimore-Washington Metropolitan Park, Recreational and Open Space Advisory Committee be brought into existence to serve the needs defined below and as outlined in the Report. The State Planning Department should initiate this in cooperation with the Department of Forests and Parks.

(a) Provide a discussion forum for all planning and governmental agencies in the Baltimore-Washington metropolitan area.

(b) Develop a sufficiently informed and determined publicly oriented body to articulate the needs of all reaches of the metropolitan area.

(c) Resolve conflicting land use objectives which could rise between counties having as a common boundary the Patuxent River.

(d) Assist the less experienced basin counties to define and plan for meeting their respective local and regional obligations to provide public lands for general citizen usage.

(e) Help the basin counties with more limited financial resources to find ways and means of financing planning and land acquistion.

(f) Develop intra-basin county cooperation in land acquistion and recreational development activity in instances where, for example, Prince George's County plans to acquire and develop land for recreational use on the west shore to the Patuxent River and would desire reasonable assurance of non-conflicting land use on the Anne Arundel County shore. 
Foster the development of regional approach sufficiently determined to take maximum advantage of the many-faceted Federal assistance programs for recreational and open-space planning and acquisition.

(h) Encourage the development of a role for the State Department of Forests and Parks as coordinator of planning and land acquisition activity more in keeping with the continually growing financial assistance role of the State.

It is also recommended that portions of the Patuxent River be considered for inclusion in the scenic rivers program as defined in the Maryland Scenic Rivers Act of 1968.

8) It is recommended that that the Governor's Office initiate the formation of Patuxent Basin Council and that the Council itself determine its leadership and staff requirements. In addition to the recommended membership, Fort George G. Meade should be included as it is an autonomous jurisdiction within the State. Discussion of the establishment of such a Council should not delay the formation of the recommended advisory committees nor influence carrying out the recommendations with more immediate implications.

We also suggest for your consideration the following steps which the Advisory Committee and Technical Task Force agencies could take to implement the recommendations made in the Report as modified by the State Planning Department:

1) Review and adoption of the Report with the Committee's disposition of the Report set forth in a brief statement prepared by the Advisory Committee independent of assistance of the State Planning Department.

2) A special Task Group of State agency representatives consisting of the Departments of Forests and Parks, Health and Water Resources, State Planning Department, and the Technical Task Force member representing the regional planning agency(s) covering the county should visit each county to discuss the recommended program and to elicit the county's cooperation.

3) The Advisory Committee members should transmit the Report to their respective counties and at the same time request the county to cooperate with the Task Group in discussing the program recommendations.

4) After adoption by the Advisory Committee, the Report should be submitted to the Governor requesting that he direct the State agencies to comply with the recommendations and the regional planning agencies to cooperate fully with the State.

5) On or about August 1, 1968 and October 1, 1968, the Advisory Committee should conduct a full review-through the specified Task Group agencies-of the status of the implementation of the recommendations made.

1 would at this time like to express my appreciation for the full cooperation afforded our Department in undertaking this effort by the Governor's Patuxent River Advisory Committee, the member agencies of the Patuxent Technical Task Force, the Federal Water Pollution Control Administration, and the elected officials and administrative personnel of the Patuxent Basin counties.

Sincerely,

/s/ James J. O’Donnell

James J. O'Donnell

Director 
Appendix B 



\author{
MARYLAND \\ STATE PLANNING DEPARTMENT \\ HISTORICAL RECORD OF \\ THE PATUXENT WATERSHED \\ STUDY PROGRAM AND \\ COMMENTS ON THE FINDINGS AND \\ RECOMMENDATIONS OF
}

\author{
REPORT \\ ON A RE-EXAMINATION OF \\ THE WATER AND RELATED LAND \\ RESOURCES PROBLEMS OF THE \\ PATUXENT RIVER BASIN \\ February 14, 1968
}

\author{
Prepared for the \\ Governor's Patuxent River Watershed \\ Advisory Committee \\ May 31,1968
}




\section{TABLE OF CONTENTS}

Background

Role of State Agencies and Regional Planning Agencies . . . . . . . . . . . . . . . . . . . 44

Role of the U.S. Department of the Interior Federal Water

Pollution Control Administration (FWPCA) . . . . . . . . . . . . . . . . . . . . . 44

Philosophy Adopted in the Patuxent Watershed Study Program . . . . . . . . . . . . . . . . . 44

Response of State Agencies and Regional Planning Agencies to

Patuxent Watershed Study Program . . . . . . . . . . . . . . . . . . . 45

State Planning Department Comments on Report Text _. . . . . . . . . . . . . . . . . 45

State Planning Department Comments on Report Recommendations . . . . . . . . . . . . . . . 47 


\section{Background}

The changing character of the Patuxent Watershed and the implications for the future of the basin have been an official State concern of several years' standing. This concern has been expressed in the creation of several review and coordinating committees which have both county and legislative orientation and membership.

Early efforts were directed at developing and implementing a waste collection and treatment system and the provisions of the Patuxent Wátershed Act of 1961-an act primarily concerned with the reservation of park and open-space lands throughout the watershed. These earlier efforts were, in their own way, successful and are the present basis for on-going activity in the watershed.

In January 1967, acting in response to recommendations of the Patuxent River Watershed Sub-Committee of the Legislative Council and the Board of Natural Resources, then Governor J. Millard Tawes appointed the Governor's Patuxent River Watershed Advisory Committee under the chairmanship of former Senator John T. Parran, Jr. The Governor stated in his charge to the newly appointed Committee that:

"... recognizing the threat of pollution, erosion, and urban encroacliment to the Patuxent River Watershed, the purpose of this Committee is to determine what can be done to save the watershed and to initiate a plan for its development so that the pollution of this river and its tributaries may be abated."

In accordance with a further recommendation of the Board of Natural Resources, the Advisory Committee called upon the State Planning Department to provide necessary staff assistance in the preparation of the program called for. The Planning Department in turn requested that State agencies, regional planning and service agencies, and the Federal Water Pollution Control Administration designate staff members to participate on the Patuxent Technical Task Force and assist in making a coordinated effort to analyze and evaluate Patuxent Watershed problems and management needs and to develop proposals for ways and means of preventing deterioration and preserving and enhancing the Basin's environmental values. To assist the Planning Department and the Patuxent Technical Task Force in this effort, a consultant, Melvin E. Scheidt, was retained. Partial financial support for the activity was received from the Federal Water Resources Planning Act of 1965 administered by the Maryland Department of Water Resources.

While the State Planning Department has no statutory responsibility for implementation of the recommendations growing out of the Patuxent Study program, it did serve as a catalyzer and coordinator of Technical Task Force and consultant activity.

\section{Role of State Agencies and Regional Planning Agencies}

The agencies represented on the Technical Task Force are, to the State, the most significant sources of technical expertise and professional informed judgement regarding water and related land resource development in Maryland. And, not to be overlooked is the fact that several of these same agencies have vested in them by the General Assembly statutory responsibilities to carry out the policies of the State and administer and manage its natural resources.

Regional planning agencies represent a similar expertise and informed professional judgement in matters pertaining to the physical development and problems in land use within the Patuxent Watershed.

Both groups of agencies participated in eight separate Technical Task Force sessions in addition to several other meetings involving two or more of the Task Force members. These sessions were devoted to the following matters:

(a) Role of the Technical Task Force.

(b) What to strive for in the Patuxent Study programs.

(c) Delineation of Patuxent Watershed problems.

(d) Discussion of the Watershed's problems and possible remedial program approaches.

(e) Assistance to the Federal Water Pollution Control Administration and the consultant in developing the technical base of information for their respective reports.

Review and critique of the progress and interim reports of the consultant.

Assistance to the consultant and State Planning Department in the 
development of program recommendations and an implementation strategy.

The participating agencies were also requested to comment formally on the Final Draft of the consultant report, "Report on a Re-Examination of the Water and Related Land Resource Problems of the Patuxent River Basin-February 14, 1968" hereafter referred to as the Report. These comments are made a verbatim part of the final report as Appendix VII.

\section{Role of the U.S. Department of the Interior-Federal Water Pollution Control Administration (FWPCA)}

The Chesapeake Field Station of the FWPCA had, prior to the formation of the Patuxent Technical Task Force, initated a mathematical model study of water quality in the Patuxent Basin above the tidal estuary. This effort was in response to the Clean River Restoration Act of 1966 (PL89-753), particularly the provisions regarding Comprehensive Programs for Water Pollution Control.

After discussion between the State Planning Department, Department of Water Resources, State Department of Health, the Governor's Patuxent River Watershed Advisory Committee and the FWPCA, it was agreed that the fullest cooperation in matters relating to Patuxent water quality analysis was most desirable. With this in mind, the FWPCA offered to share its expertise and knowledge with the Technical Task Force.

During the course of the study, the FWPCA has continuously provided to the Technical Task Force and particularly to the Departments of Water Resources and Health direct technical support relative to Patuxent water quality analysis and control needs.

The relationship between the Technical Task Force through its member agencies and the FWPCA has been an exemplary experience in Federal-State cooperation.

Maryland has benefited and will continue to benefit from the expertise and specialized services of the Chesapeake Field Station personnel. In turn, the Departments of Water Resources and Health are directly assisting the FWPCA in implementing the provisions of the Water Pollution Control Act of 1965 which called for the adoption of a water quality control program by the several States. By assisting the State, the FWPCA has clearly recognized Maryland's responsibility to implement the adopted water quality standards and has strengthened the State's ability to do so.
While the FWPCA Patuxent Basin Comprehensive Water Quality Program will present several alternative approaches to waste water management, the State has the responsibility for choosing between alternatives and developing the organizational and administrative apparatus necessary to implement the selected control program. The report of the Governor's Patuxent River Watershed Advisory Committee, as adopted and implemented, will in large measure constitute this aspect of the Patuxent Basin waste water management approach.

\section{Philosophy Adopted in the Patuxent Watershed Study Program}

It was clearly apparent to the Governor's Patuxent River Watershed Advisory Committee and to several of the State agencies that the Patuxent Watershed had been "studied to death" with little appreciable impact on what was actually occuring in the basin. At the same time, it was recognized that specific additional study would be needed to fill information gaps in order to develop meaningful programs directed to the problems indentified. Also, as previously mentioned, the technical expertise, informed professional judgement and statutory responsibility directed towards water and related land resource problems was available in the State and had to be mobilized and directed towards the problems of the Patuxent Basin.

For these reasons, the State Planning Department from the outset attempted to encourage the study effort to move directly from reconnaissance planning into implementation of a recommended program. It was hoped that by directly engaging the responsible State and regional agencies and by enlisting the support of county officials in the Patuxent Basin through the Governor's Patuxent River Watershed Advisory Committee in the reconnaissance planning phase this would be possible. The spirit of the program recommendations offered indicate, at the least, partial success in this respect.

In the course of the study program and in discussing and developing program recommendations, it became quite clear that some means of formalizing the communication flow between State agencies, regional planning agencies, local governmental agencies, public officials at all levels and decision-makers at all levels was a must. It was obvious that it could not be taken for granted that communication-even where clearly necessarywould spontaneously arise. And, without this communication, the full impact of the State's and county's technical, financial and intellectual re- 
sources and decision-making authority would not be brought to bear on the problenis indentified.

The state could provide technical guidance to county and local governments. However, county and local elected officials and administrators had a very significant responsibility in accomplishing the implementation phase of any recommended program. For this reason, the organizational recommendations to facilitate communication implicitly embody this important relationship.

The decision to work closely with the FWPCA on water quality matters was an important one. There seemed to be no reason for the State not making the best cooperative use of the tools and talent available to it out of reluctance to working closely with Federal personnel in water pollution control matters. The decision has proved to be a correct one in all respects.

Response of State Agencies and Regional Planning Agencies to Patuxent Watershed Study Program

The sustained support of the agencies and their representatives was critical to the success of the Technical Task Force and the study program.

During the course of the study, several specific actions were initiated by the cooperating agencies. This constituted implementation of recommendations or phases of recommendations and was a direct or partial result of discussion by the Technical Task Force. The actions which have already been initiated are discussed more fully in the February 14, 1968 Report and the discussion of Report recommendations below. Summarizing briefly, these are:

(1) Partial alleviation of a sanitary landfill pollution problem.

(2) Initiation of mathematical model study of water quality in the upper estuary.

(3) Communication between water supply study consultants active in the Patuxent Basin.

(4) Closer scrutiny of waste treatment operations in the Patuxent Basin.

(5) Preliminary consultation with waste treatment plant owners and operators indicating the likelihood of higher treatment needs and nutrient removal.

(6) Initiation of Section $3 c$ basin-wide pollution control implementation planning for the Patuxent Basin by the Department of Water Resources.
(7) WSSC strenghtening of erosion control specifications in utility installation procedures.

Several specific comments have been offered by the Technical Task Force agencies on the Final Draft. These are contained in Appendix VII of the final Report. However, there has been general concurrence on the basic recommendations.

\section{State Planning Department Comments on Report Text}

Discussion in this section is limited to comments on apparent deficiencies and weaknesses in the Report. Of more significance are the comments on recommendations discussed in the following section.

It should be pointed out that additional consideration of various aspects of the Report text are contained in the Teclinical Task Force member agencies' comments. Because of the time limitations under which the consultant was required to perform, many suggested Report text changes were not worked into the document.

\section{Population Projections}

It is clear that the population projections on page 6 for the Howard, Mentgomery and Prince George's Counties portion of the basin are conservative when compared with the populations officially and unofficially predicted for this area by the Regional Planning Council and the MarylandNational Capital Park and Planning Commission. The tables on page 46 contain a comparison of the respective projected populations.

Population projections cited in the Report are those being used by the Federal Water Pollution Control Administration in their modeling of waste treatment needs. They do not necessarily reflect the views of the planning agencies involved. While it is apparent that the populations cited and used by the FWPCA could have been more representative, the absolute magnitude of the population differences do not alter the basic conclusions and recommendations of the Report.

Furthermore, since the Report and the FWPCA technical discussion of alternatives and costs for waste treatment systems are not to be construed as engineering specifications, the expectation is that the agencies and individuals actually designing a waste treatment system would have access to the most informed views on population projection. Variations in population would influence timing of waste treatment system provision, but would not affect the basic issue-need. As a rule of thumb, 
1980 and 2000

\section{Population Projections for \\ Montgomery and Prince George's \\ County}

\begin{tabular}{lcccccc} 
County & \multicolumn{5}{c}{ Report } & \multicolumn{4}{c}{ M-NCPPC } \\
& 1970 & 1980 & 2000 & 1970 & 1980 & 2000 \\
Montgomery & 508,000 & 630,200 & $1,002,600$ & 508,100 & 643,400 & 995,000 \\
Prince George's & 621,100 & 770,300 & 870,000 & 623,700 & 792,900 & $1,192,000$
\end{tabular}

\section{Population \\ Projections for the Patuxent Basin}

$\begin{array}{llll}\text { County } & \text { Report } & \text { RPC } & \text { M-NCPPC } \\ \text { Howard } & 73,000 & 90,000-110,000 & \end{array}$

Montgomery Waste Transported

Combined Total

Out of the Basin

For Two Counties

Prince George`s $\quad 175,600$

172,700

\section{Population \\ Projections for the Patuxent Basin}

\section{County}

Montgomery

Prince George's
Report

Wastes Transported

Out of the Basin

307,900

\section{M-NCPPC}

Combined Total For Two Counties

355,000 provision for treatment should be geared to the higher range of population expectation in any rapidly growing area.

In the Anne Arundel County population figures cited on page 6, Fort Meade non-resident population is included with the Anne Arundel County resident population.

A comparsion of Table 1 (p.6) and Table 2 (p.10) indicates only a 10\% change in populations predicted between an earlier study and the figures used in this Report. When compared with text comments on page 13 (number 5), the conclusion is implied that population changes alone cannot be responsible for the new indications of a critical waste water control problem in the Patuxent Watershed. And, in fact, this is true. Other factors such as percent of population sewered and better defined Patuxent River waste assimilation characteristics have contributed to the finding that the Patuxent River system does not have the capacity to handle waste loads at present levels of treatment and stream flow, for even the most conservative populations suggested in 1980 and 2000 .

\section{Surface Water-Ground Water}

The Report does not adequately reflect the role to be played by regulated well fields in supplying water to the middle reach of the basin, particularly the Fort Meade and Anne Arundel County area. While the Report does accurately reflect the limited increased future role of surface water supply drawn from within the Patuxent Watershed, the specific comments and recommendations of the Maryland Geological Survey (letter dated April 1,1968 ) are fully endorsed as a useful supplement to the Report discussion found on page 20 and 21 and in the Findings and Recommendations which deal with water supply in the Patuxent Basin. 


\section{Estuary}

The FWPCA and associated Departments of Health and Water Resources analyses of the Patuxent Watershed water quality did not consider the estuary portion of the system. They are now looking into this reach and particularly the impact of the Western Branch Treatment Plant of the WSSC.

In the Report it is suggested that a series of studies are needed to assist in the evaluation of the estuary and the impact of treated wastes on its waters. The tone of the Report seems to lean heavily towards the need for additional study with lesser emphasis to the need for immediate attention towards collecting and analyzing existing information and data. However, there is need for additional specific short term studies. This is particularly relevant to the Western Branch Treatment Plant and its potential impact. In the longer run, more sophisticated study of the complex problems of an estuary system is certainly desired.

The Department of Chesapeake Bay Affairs (letter dated April 29, 1968) has clearly indicated their concern with the need to reach conclusions upon which waste management decisions can be made without getting overly involved in studies which are more esoteric in nature and less critical to short-run management needs. This pragmatic orientation to additional research and study needs is necessary to prevent ill-advised waste treatment activity from being allowed to exist in the Patuxent Watershed under the guise of "not knowing enough about the estuary."

\section{State Planning Department Comments on Report Recommendations}

The State Planning Department's comments on the recommendations are numerically arranged in the same order as the recommendations found in the Report.

(1) The Washington Suburban Sanitary Commission (WSSC) has commented that it would expect equitable compensation for releases of water over what they are obligated to supply. The Attorney General has ruled-Opinion of March 14, 1968 re: Maintenance of flow in Patuxent River by Washington Suburban Sanitary Commission-that a minimum flow equivalent to the smaller of either $10.5 \mathrm{mgd}$. (16.2 cfs) or the natural flow that would be in the river at Laurel if there were no regulation or diversion must be maintained at Laurel at all times. It is possible that higher levels of treatment could be substituted for greater releases of water and vice-versa (over and above $16.2 \mathrm{cfs}$ as called for). Such a trade-off should be investigated at an early date by WSSC and the Departments of Water Resources and Health. From the standpoint of early remedial action, WSSC could be asked to increase releases as a substitute for yet unavailable higher levels of treatment. As water supply needs increase demands on the T. Howard Duckett Reservoir supply (formally known as Rocky Gorge), higher treatment levels would be available to help reduce flow augmentation needed from the Duckett Reservoir.

(2) The question of what immediate action is necessary to prevent the waters of the Patuxent from further degradation, in the short-run, resolves itself into the question of State policy in handling subdivision waste treatment permits existing and newly applied for. At present, the State Department of Health has responsibility for reviewing such permits. However, there does not yet appear to be any formal procedure for handling this matter within the spirit of the critical need in the Patuxent Basin.

(a) It is strongly suggested that the Advisory Committee take a firm position on this recommendation (2a) which in short states that a strong stance be taken by the State in enforcing a subdivision permit system in keeping with the waste treatment recommendations and water quality standards for the Patuxent Basin. Such a position will clearly indicate the State's intention to catch up with and control the problem and to see adequate treatment provided in the most immediate and expeditious way possible. The State Department of Health should undertake this task and report to the Advisory Committee on action taken on or before August 1 and again, on or before October 1, 1968.

(b) Strong State action in line with recommendation $2 a$ should give further impetus to expeditiously carrying out the planning, financing and constructing of a new basin-wide waste water treatment and disposal system. The intent of this recommendation ties in directly with legislation enacted by 1968 Legislature (Maryland Law (1968)-Chapter 446) calling upon the Department of Water Resources to undertake comprehensive basin plans under the provisions of Sec. $3 c$ of the Clean Rivers Restora- 
tion Act of 1966. The framework basin plans to be prepared will provide a conceptual basis to be used in directing the integration of the county sewer and water facilities plans being prepared under the provisions of S.B. 335 and the technical information on waste treatment alternatives discussed in FWPCA Appendix II now under preparation. This procedure applies equally to the long range pollution control program discussed in recommendation $2 c$.

The Patuxent Basin is being given first priority by the Departments of Water Resources and Health. Initial planning to implement this recommendation is now underway. (See Department of Water Resources letter dated May 1, 1968). It is recommended that the State Departments of Health and Water Resources withhold approval of any county water and sewer facilities plan not in conformance with the water quality management recommendations adopted by the Governor's Advisory Committee.

The existence of a comprehensive basin-wide pollution control program would enable the local jurisdictions and the State to receive up to a $10 \%$ premium in Federal matching grant monies applied to facilities constructed throughout the basin. While the four upper basin counties are now entitled to receive such a premium because they are part of a regional planning district, the three Southern Maryland counties are not now covered and will benefit from the implementation of recommendation. $2 b$. In addition, all jurisdictions would benefit from the availability of demonstration grants in which waste treatment facilities demonstrating new techniques can be funded up to $70 \%$ of the cost with Federal grant monies under provisions of the Clean Rivers Act of 1966.

(c) For the longer range, the recommendations contained in $2 c$. for giving consideration to various waste treatment alternatives is valid. However, the short-run needs should not be subordinated to longer-run consideration.

(3) Regardless of what governmental level shares primary responsibility for planning, financing, constructing and operating the waste treatment system in the Patuxent Basin, it will be necessary to have the advice and guidance of a locally oriented group such as the recommended Patuxent Basin Sanitary Advisory Committee. In addition to the recommended membership, Ft. George G. Meade should be included on the Advisory Committee.

The 1968 General Assembly assigned to the Department of Water Resources responsibility for administering Sec. $3 c$ of the Clea $\mathrm{n}$ ivers Act of 1966-implementation planning for comprehensive river basin pollution control program. To be consistent with the concept suggested by recommendation $2 b$, it is recommended that the Department of Water Resources, in cooperation with the State Department of Health, be responsible for organizing such an Advisory Committee, rather than the State Department of Health as indicated in the February 14, 1968 Report.

(4) The Department of Water Resources is now initiating the development of a mathematical model for water quality in the lower portion of the Patuxent River: the area not covered by the existing FWPCA model. They intend to develop this model with the cooperation of the FWPCA and the Chesapeake Bay Institute (CBI) of The Johns Hopkins University. And, as indicated in the Report, the Chesapeake Biological Laboratory (CBL) of the Natural Resources Institute will be undertaking a study of the biological characteristics of the Patuxent Estuary.

It does not appear necessary at this time for the Governor to request additional technical assistance from the FWPCA. However, it is strongly recommended that the Department of Water Resources develop a formal working relationship with CBI, CBL, FWPCA and the Departments of Chesapeake Bay Affairs and Game and Inland Fish in the course of developing the Patuxent Estuary model. Such a grouping could be constituted as a sub-committee of the proposed Sanitary Advisory Committee.

(5) This recommendation is of a policy nature and subject to further discussion and possible modification depending on the selection from the range of alternatives analyzed by the FWPCA in Appendix II.

(6-7) The rapid change in land-use in the Patuxent Watershed lends immediacy to the need to follow through on erosion control activity. At the present time, the Department of 
Water Resources is initiating the development of a State-wide sediment control program. They have indicated that an Erosion and Sediment Control Committee for the Patuxent Watershed alone would not be necessary. However, because of the rapid rate at which land will be bared in the basin for subdivision development, utilities installation and road construction, it is strongly recommended that the Department of Water Resources formally approach the basin counties and, with the cooperation of the Soil Conservation Service, State Roads Commission and Department of Chesapeake Bay Affairs, encourage and assist in the preparation, execution, and enforcement of sediment control programs. While it may be that such local control programs will be superseded by a State-wide program, action in the Patuxent Basin should not be delayed for that reason alone.

The Washington Suburban Sanitary Commission has recently added to their utility installation contractual specifications provision for strengthening erosion control measures. In this regard, the Department of Water Resources and Soil Conservation Service have offered technical assistance and advise to the WSSC.

(8) Consultants involved in planning for future water supply in the Baltimore-Waslington Metropolitan area have already initiated discussion recommending that the consultants and agencies involved extend their discussions to include the ground water interest of the Maryland Geological Survey and the water supply role played by the Maryland House of Correction and State Department of Public Improvements. Furthermore, it is recommended that the State Planning Department inform the Regional Planning Council (Baltimore), Metropolitan Washington Council of Governments, Ft. George G. Meade and the Maryland Department of Public Improvements of these recommendations.

$(9,10$, The question of land reservation in the 11) Patuxent Watershed for open space and recreational use is three dimensional in nature. First, the Patuxent River is a boundary of all the counties in the basin. Second, land development pressures are being exerted on the basin in response to growth pressures from the Batlimore and Washington Metropolitan area-both for subdivision or "new town" development and land for urban recreation. Third, optimum development of the basin's recreational resource requires the excellent water quality be maintained and greater, yet compatible, use of the Washington Suburban Sanitary Commission water supply reservoirs be negotiated.

During the course of discussion by the Technical Task Force on this issue, four points were repeatedly raised:

(a) There were several jurisdictions and agencies either planning or assisting in the acquistion of land in the Patuxent Watershed.

(b) The Patuxent Watershed Act of 1961, as a source of financial assistance, is being under-utilized by the counties.

(c) Some of the smaller counties did not have the financial means to even share in the cost-sharing program under the Act of 1961 .

(d) There has been much study directed to land acquisition and reservation, but very little implementation activity.

It seems quite apparent that there is a critical need to develop an organizational arrangement capable of serving several needs related to park, recreation and open space planning and acquistion:

(a) Providing a discussion forum for all planning and governmental agencies in the Baltimore-Washington Metropolitan area.

(b) Developing a sufficiently informed and determined publicly oriented body to articulate the needs of all geographic areas in the metropolitan area.

(c) Resolving conflicting land use objectives which could arise between counties having as a common boundary the Patuxent River.

(d) Assisting the less experienced basin counties to define and plan for meeting their respective local and regional obligations to provide public lands for general citizen usage.

(e) Helping the basin counties with more limited financial resources to find ways and means of financing planning and land acquisition.

(f) Developing intra-basin county cooperation in land acquistion and recreational development activity in instances 
where, for example, Prince George's County plans to acquire and develop land for recreational use on the west shore of the Patuxent River and would desire reasonable assurance of non-conflicting land use on the Anne Arundel County shore.

(g) Fostering the development of a regional approach to take maximum advantage of the many faceted Federal assistance programs for recreational and open-space planning and acquisition.

(h) Encouraging the development of a role for the State Department of Forest and Parks as coordinator of planning and land acquisition activity more in keeping with the continually growing financial and technical assistance role of the State.

It is strongly recommended that a Baltimore-Washington Metropolitan Park, Recreational and Open Space Advisory Committee be brought into existence to serve the needs defined above and as outlined in the February 14, 1968 Report. The State Planning Department should initiate this in cooperation with the Department of Forests and Parks.

It is also recommended that the Patuxent River be considered for inclusion in the scenic rivers program as defined in the Maryland Scenic Rivers Act of 1968.
(12) The role to be played by a Patuxent Basin Council is essentially that of providing an organizational umbrella under which the duly designed representatives of the governmental jurisdictions could act together and to which the various advisory committees would be accountable. Such a Council-Advisory Committee set up would attempt to knit together the State's administrative and management agencies who have statutory responsibilities for resource management with the local elected and administrative officials who have a political responsibility for activity within their jurisdiction.

It is recommended that the Governor's Office initiate the formation of such a Council and that the Council itself determine its leadership and staff requirements. In addition to the recommended membership, Ft. George G. Meade should be included as it is an autonomous jurisdiction within the State. Discussion of the establishment of such a Council should not delay the formation of the recommended advisory committees nor influence carrying out the recommendations with more immediate implications. 



\title{
THE PATUXENT RIVER
}

MARYLAND'S ASSET, MARYLAND'S RESPONSIBILITY

Report on a Re-Examination of the Water and Related Land Resource

Problems of the Patuxent River Basin

\begin{abstract}
APPENDICES
GOVERNOR'S PATUXENT RIVER WATERSHED ADVISORY COMMITTEE
\end{abstract}


MARYLAND STATE PLANNING DEPARTMENT

1103 State Office Building

Baltimore, Maryland 21201 
During the course of the last several months, several supplementary papers on the Patuxent Basin have been prepared by the Patuxent Technical Task Force. These papers are augmented by other appendices dealing with water quality standards, sediment control activity and the comments of member agencies of the Technical Task Force.

The Appendix is a compilation of these papers and supplementary appendices.

The Governor's Patuxent River Watershed Advisory Committee and the State Planning Department are grateful for the cooperation of the Patuxent Technical Task Force in assisting in the preparation of these appendices.

Robert M. August

State Planning Department

Chairman, Patuxent Technical Task Force 

TABLE OF CONTENTS

\section{APPENDICES}

I - MARYLAND WATER QUALITY STANDARDS APPLICABLE TO PATUXENT RIVER BASIN

III - SUMMARY REPORT ON ENVIRONNENTAL CONDITIONS OF THE TIDAL PATUXENT RIVER

IV - FISHERY RESOURCES OF THE PATUXENT RIVER SYSTEM

V - SEDIMENT AND EROSION CONTROL IN MONTGONERY COUNTY, MARYLAND

VI - STATE AGENCY AND REGIONAL PLANNING AGENCY COMNENTS 

APPENDIX I

MARYLAND WEATER QUALITY STANDARDS

APPLICABLE TO THE PAIUXENT RIVER BASIN 



\section{Classification of Vater Uses and Controlling Quality Standard}

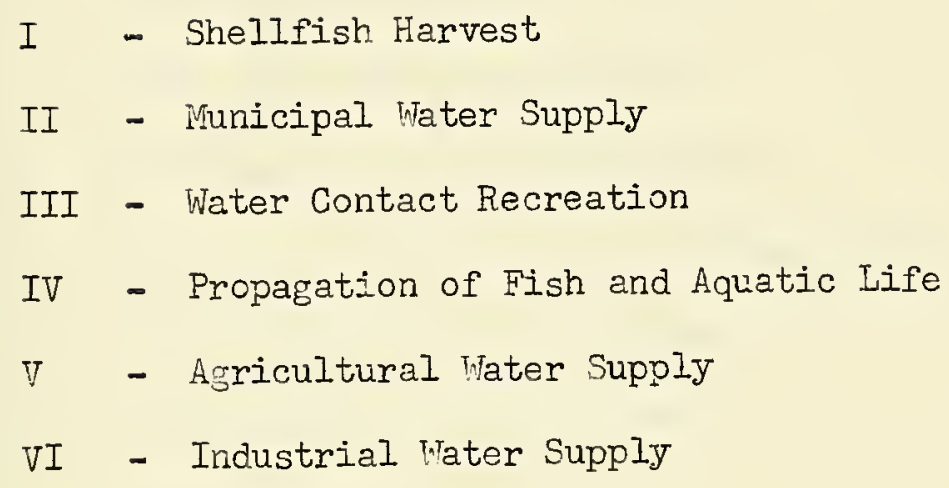

For the specific standards required to be met under the several catagories listed above, reference should be made to Maryland Water Resources Regulation 4.8 , issued by the Water Resources Commission and the Department of Water Resources of Maryland, May 22, 1967. 



\section{Water Use Classifications Designated for the Patuxent Basin}

Mainstem and Tributaries

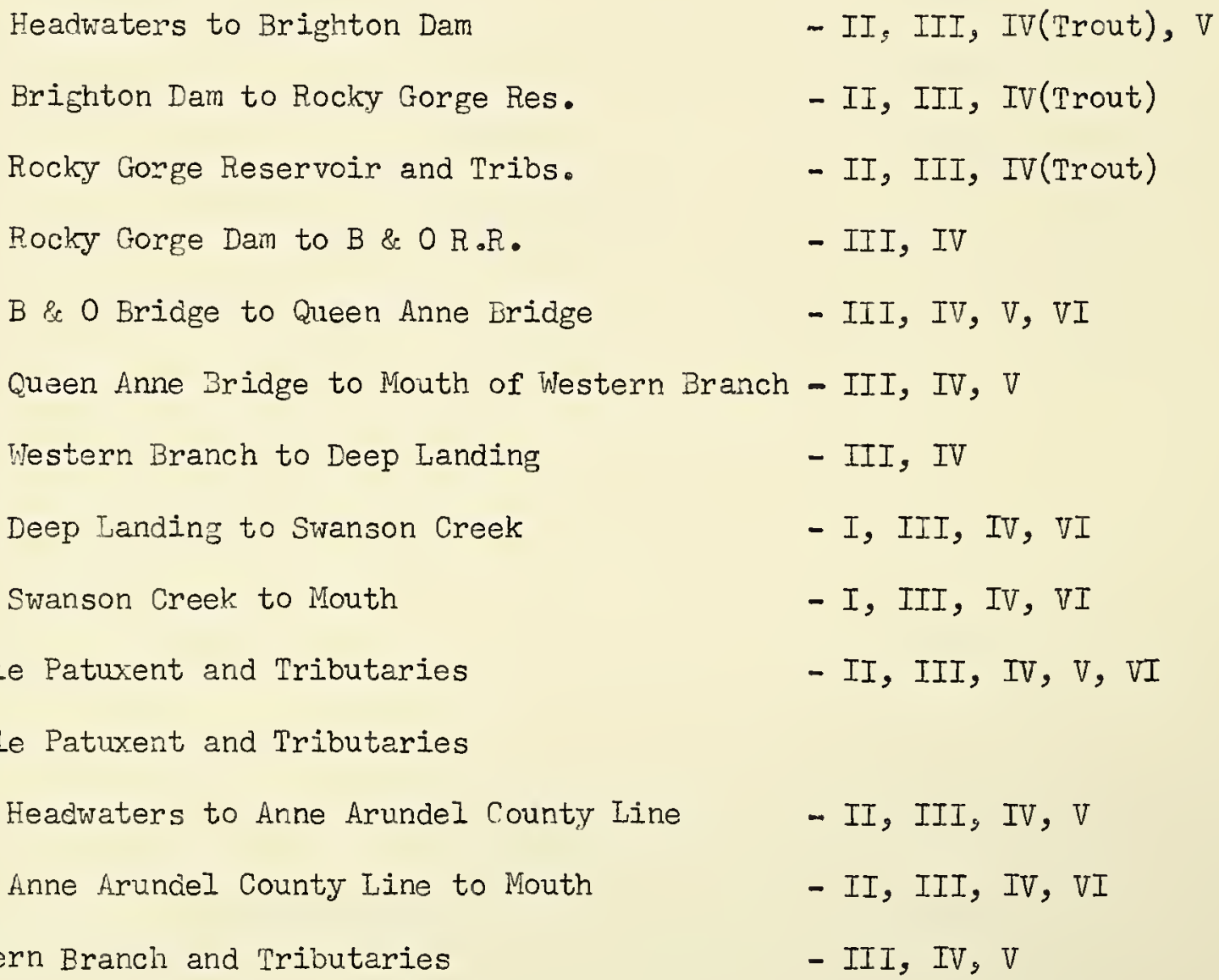

Attention is called to the fact that water Contact Recreation and Propagation of Fish are designated uses for all of the streams of the basin. If the quality standards required to support these uses are met, the waters in all cases will be satisfactory for all other uses except in the lower two reaches of the estuary. In these latter two sections, the bacterial standard required for support of shellfish harvesting is more stringent than that required for water contact recreation and is, therefore, controlling. 





\title{
Appendix III
}

Summary Report on Environmental

Conditions of the Tidal Patuxent River

\author{
Joseph A. Mihursky \\ University of Maryland \\ Natural Resources Institute \\ Ref. No. 68-7
}

Prepared for Use by the Patuxent Technical Task

Force Comittee

January, 1968 

The region of the Patuxent discussed in this report extends from Hill's Bridge (Rte. 4 at Vayson's Corner) to the mouth of the river at Drum Point, a distance of about 45 miles (see map).

\section{PHYSICAI, CHARACIERISTICS}

The river's width varies from less than .1 mile in the upper tidal reaches to over 2 miles in the lower reach. Channel depths generally increase from upriver to downiver with the section froin Hill's Bridge to Benedict Bridge ranging from about 51 to $10^{\prime}$. From Benedic ${ }^{\prime}$ Bridge south depths range from $33^{\prime}$ to $120^{\prime}$. Average tidal ranges are $2.5^{\prime}$ at Nottingham, 1.9' at Benedict Bridge and $1.2 '$ at Solomons. The extreme in tidal range recorded at Benedict Bridge between 1963 and 1967 was $5.7^{\circ}$.

The lower Patuxent estuary is typified as a two-layered system with a net upstream movement of subsurface high salinity (and high density) waters and a net downstream movement of fresher (less dense) surface waters over eadh tidal cycle.

\section{WATER QUALITY CHARACTERISTICS}

Water quality information is available from Hill's Bridge to Solomons; however, data from Hill's Bridge to Lower Marlboro is not as extensive as from Lower Marlboro to Solomons.

Temperature

Surface water temperatures may reach $30-32^{\circ} \mathrm{C}$ during extended hot, humid periods while ice formation is common from Hill's Bridge to Benedict Bridge during mid-winter. Cccasionally during extremely cold periods the estuary will freeze to Sheridan Point.

Operation of a steam electric station at Chalk Pt. uses 500,000 gallons of water per minute for cooling purposes and depending on pumping rates, heats the water $11.5^{\circ} \mathrm{F}$ in the warmer seasons and $23^{\circ} \mathrm{F}$ during winter periods. Discharge temperatures commonly approach $100^{\circ} \mathrm{F}$ during summer months. Surface temperatures as high as $95^{\circ} \mathrm{F}$ have been recorded in a $3 / 4$ mile area around the discharge point.

\section{Salinity}

Measurable salinity generally begins in the Nottingham to Lower Marlboro region; however, due to seasonal differences in fresh water input, the salt wedge apparently may extend only to Folland Cliff, or as far upriver as Hill's Bridge, a shift of over 20 miles.

Highest salinities throughout the estuary are generally reached during November while lowest values prevail during April. A gradual increase in salinity occurs from the Nottingham - Lower Marlboro region to Solomons, with values over 20 parts per thousand occasionally reached at the river mouth. Nean low salinities at Solomons may fall to 10-1l ppt and mean highs may reach $14-16$ ppt. 

In recent years salinities have been increasing, apparently due to water diversion practices in the upper basin as well as to recent extensive drought conditions.

\section{Suspended Material}

It has been estimated that 183,000 tons of sediment are deposited in the estuary per year. Turbidity measurements show relatively high values in the estuary between Hill's Eridge and Benedict Bridge with water color generally a brown or green brown. Below Benedict Bridge water clarity improves and color is generally green, clear green. Apparently a decrease in water velocity as well as a "salting out" effect above Benedict Bridge causes almost all of the suspended sediments to be deposited before being carried into the lower estuarine reach below Benedict Bridge. In addition to suspended sediment from soil erosion and gravel washing operations, the water column carries a quantity of detritus, chiefly fragmented marsh vegetation. As a result of above described characteristics, the estuary tends to have a mud and detritus bottom from shelf to channel in the area from Hill's Bridge to Lower Marlboro; from Lower Marlboro to Benedict Bridge occasional sand and pebble shore and shelf areas begin to develop; below Benedict Bridge the channel is composed of finely divided silts and clays and extensive sandy beach and shelf areas occur.

\section{Nutrients}

Scattered unpublished information has indicated an increase in nutrients (phosphates and nitrates) in the upper non-tidal portion of the basin due to discharges from sewage treatment plants. As one proceeds down the estuary, nitrate values diminish and show narked seasonal variations, with minimal values in sumer and early fall, a gradual winter buildup with maximum values obtained during the spring. Algae production increases in spring and apparently causes a redaction in nitrates in the estuary during the warmer seasons. Marsh vegetation may also be responsible from nutrient reduction during the active growing season of marsh plants.

Phosphate values do not exhibit any marked upriver - downriver patterns nor do they exhibit any marked seasonal variations. Apparently phosphate turnover is very rapid in the Patuxent estuarine system and does not appear to be limiting at any time to phytoplankton growth.

\section{Trace Elements}

Trace element studies have shown conditions of the same order of magnitude as most majo" rivers in North America. However, the hardness of Patuxent water is less than many large rivers (i.e., 1/5 that of the Potomac). Concentrations of manganese, boron and rubidium are higher and chromium, copper, lithium, nickel and strontium, lower than most major rivers. Other trace elements are about the same in the Patuxent as most other rivers.

\section{Oxygen}

Limited date on dissolved oxygen concentrations in the estuary reveal occasional slight summer sag conditions in the Hill's Bridge area and in the deeper channel portions of the lower estuary. Upriver depletions are 

probably due to organic loads coming from upriver sources while downriver depletions probably reflect periods of little water turnover coupled with light reduction in the deep water zones.

Biochemical Oxygen Demand (B.O.D.)

B.0.D. from Hill's Bridge downstream generally fall in the "good" category of Maryland's stream classification, i.e., daily maximum of not more than $3.5 \mathrm{ppm}$.

\section{BIOLOGICAL CHARACTERISTICS}

Bacteria

Numbers of Coliform bacteria, although sometimes reaching very high numbers in the non-tidal section of the basin, tend to drop precipitously from Hill's Bridge south. Most probable numbers (MPN) tend to average about 1,000/100 $\mathrm{mI}$ at Hill's Bridge and drop to less than 10/100 $\mathrm{ml}$ at Benedict Bridge.

\section{Primary Production}

Data on primary production is only available from Lower Marlboro, south. Standing crop information on algae as meansured by chlorophyll "a" extraction shows distinct seasonal patterns with minimal values ( $\mathrm{lmg} / \mathrm{m}^{3}$ ) occurring during winter and maximal values ( $50 \mathrm{mg} / \mathrm{m}^{3}$ ) occurring during warmer seasons. Highest standing crops measured between 1962 - 1967 consistently occurred in the uppermost study area around Lower Marlboro.

Algae production rates as measured by radioactive carbon uptake show highest production per unit volume in the same I,ower Marlboro area. In his paper on primary production Stross concluded "Normally, large assimilation

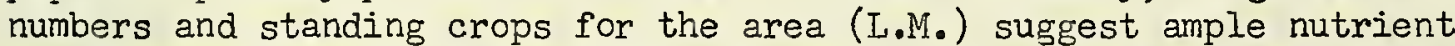
supplies are available for photosynthesis." Present studies do show highest nutrient levels at this uppermost study station compared to other downriver localities. On a per-unit-volume basis the estuary below Benedict Bridge is only about $1 / 3$ as productive as the reach in the Lower Marlboro area. However, because of a deeper euphotic zone, the lower estuary, on a surface area basis is more productive than the upper turbid reach. Mean daily rates for a year are given at $1.8 \mathrm{~g} \mathrm{c} / \mathrm{m}^{2}$ for downstream and $1.2 \mathrm{~g} \mathrm{c} / \mathrm{m}^{2}$ upstream (I.M. area). As mentioned earlier, no primary production data is available above Lower Marlboro.

Although not known for certain, at present it does appear that this low salinity area (and perhaps above) is potentially the most productive area of the estuary; however, high turbidities with consequent shallow light penetration may retard full photosynthetic activity. Paucity of current and water mixing data and additional nutrient-primary production data prevent development of a definitive evaluation. No known "algae bloom" problems, similar to those developing on the Potomac, have as yet developed on the Patuxent estuary. 

Since 1963, extensive research has been undertaken on estuary zooplankton from Lower Marlboro (L.M.) to Eroomes Island (B.I.). This segment of the food chain comprises one of the chief consumers of estuarine primary production and is undoubtedly a key factor in energy flow towards recreationalyy and commercially important finfish. One group, the copepods, dominate catches, with one species (Eurytemora affinis) dominating catches above Benedict Bridge in lowest salinities, while another species (Acartia tonsa) dominates catches below Benedict Bridge in higher salinities. Production estimates for A. tonsa during summer periods vere reported as 1.6 to 1.8 1b./acre per day. At least $1 / 2$ of the planktonic primary production in the study area (I.M. to B.I.) is believed consumed by A. tonsa during the summer months.

Field studies reveal heavy populations of sea nettles up to the Benedict Bridge - Trueman Pt. vicinity while ctenophores extend a slightly greater distance upriver. Laboratory studies indicate that $52 \%$ of cropping of Acartia tonsa could be ascribed to predation by ctenophores.

\section{Epibenthos}

Studies on epifaunal or marine fouling cominunities from Lower Marlboro south, have continued since 1963. Pertinent to our present interests, the highest production for a single month was observed at Lower Marlboro where dry weight production reached $2,754 \mathrm{~g} / \mathrm{m}^{2} / 30$ days. At this same station the highest yearly average dry weight of $6,500 \mathrm{~g} / \mathrm{m}^{2}$ was produced, 8 times the least dry weight produced at a downriver station below Benedict Bridge.

\section{Benthos}

Although many benthic surveys have been undertaken in the Patuxent, studies have not extended upstream beyond Lower Marlboro. Studies of shelf and channel populations using special dredges and screening with $1 / 2 \mathrm{~mm}$ mesh screens have yielded populations as high as 100-200,000 organisms per square meter.

Although these various benthic animals play an important role in the food chain of the estuary and at present play an unknown role in the energy flow, the species having the greatest economic importance are: 1) the blue crab, 2) the oyster, and 3) the soft shell clam.

Blue crabs spawn in the lower Chesapeake, but use the Patuxent for a nursery and mating area. Populations may extend slightly above Lower Marlboro depending on season and salinity. Comnercial operations are restricted to trot lines, The commercial catch of crabs for the Patuxent in 1965 was 80,000 lbs. Traditionally, there has been considerable fluctuation in year class success of crabs and as a result large fluctuations in commercial harvest occur. 


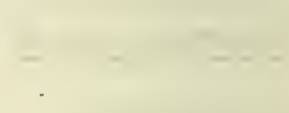


Results of a fishery creel census conducted from 1 Nay to 2 Nov. 1963 show crabbing to be an important recreational activity in the Petuxent, with 4 crabs taken for every 5 fisin caught by fisherman. About $1 / 6$ of the sport fishing population is engaged in crakbing.

Oyster populations extend to "Larmers Barl" just north of Chalk Point; however, commercially worked bars extend only to Teague's Pt., a short distance above Benedict Bridge. Both public and private holding are worked in the river with annual harvest ranging between 40-36,000 bushels.

New management procedures of increased seed planting from other estuaries has resulted in a significant increase in harvestable oysters. The Fatuxent does not have a high spatfall, but it is noted for its high fattening qualities.

Soft shell clams occur from the river mouth to Trueman Pt.; however, commercial operations extend only to Sheridan Pt. High mortalities combined with lack of year class success, apparently due to natural high water temperatures, caused a great reduction in commercial harvest in recent years. Recent.studies have shown a good recovery in the population. The 1965 commercial catch was 16,500 bushels.

Fish

The Patuxent estuary from Hill's Bridge to the mouth serves as habitat for over 60 species of fish. Included are those that 1) may spend their entire life history within the Patuxent, 2) those that use the estuary only for spawning and nursery, 3) those that use the estuary for nursery only, and finally, 4) those that are seasonal transients.

Recreationally or commercially important species include the white perch, striped bass, white catfish, spot, yellow perch, American eel, and members of the herring family. Creel census data from Holland Cliff to Jack Bay for 1963 reveal 54\% of the sport fishing catch was white perch. An estimated 15,400 angler trips were spent on these 10,330 acres (Holland Cliff to Jack Bay) in a six-month period, May to October 1963, with a total of 105,000 fish and crabs harvested.

Commercial fishing utilizes drift, stake, and anchor gill nets, haul seines and occasionally, pound nets. Most of the commercial operations extend from Jones Pt. - Nottingham to the river's mouth. Gill netting dominates operations during the colder seasons and ceases during the summer. Haul seining occurs chiefly during the spring spaming run period of striped bass (March - May). Commercial catches in recent years have ranged from $100,000 \mathrm{lbs}$. in 1965 to over $800,000 \mathrm{lbs}$. in 1951 .

\section{Miarsh and Aquatic Plants}

A vegetation study throughout the estuary listed 147 species of marsh, submersed and immergent plants for the section of the river included in this report. Unlike a number of other areas in the Bay system where rooted aquatic vegetation, especially water milfoil has interfered with normal water use, the Patuxent has been free of such problems. A change in plant species composition has been reported in the heated water area around the Chalk Pt. power plant outfall, however. 



\section{PROBIEMS}

\section{$\underline{\text { Physical }}$}

Very little dredging and filling has occurred in the tidal Patuxent to date. Pepco at Chalk Pt., completed a series of dredging and filling operations during its active construction phase (1960-64) which caused a local increase in suspended material. Filling has created a "deflector" structure a number of acres in size, which extends to the channel from Chalk Pt. A discharge canal leading to the channel at Eagle Farbor has also been constructed. Although contemplated, no known filling of the tidal marshes has yet occurred.

\section{Water Quality}

Except for power plant activities at Chalk Pt., the suspended sediment load and the increased organic load coming in to the Patuxent at the Hill's Bridge area, the entire Paturent estuary is in a relatively high quality condition. Projected increases in organic loads in the upper tidal reaches could cause dissolved oxygen reduction that would interfere with spawning activity and production of endemic as well as migratory species. In addition, nutrient additions from the breakdown of sewage could create suitable conditions for development of algae blooms similar to those reported on the Potomac. If algal population becomes too dense, high nighttime respiration, as well as large masses of decomposing algal cells, can cause oxygen depletion. of additional concern is the development of toxic forms. Little is understood about such happenings except that they tend to occur when nutrient levels have become quite high. No known nutrient problems presently exist in the tidal Patuxent; however, nutrients tend to increase as one proceeds upriver from Lower Marlboro and this section presentiy seems to have a high potential for additional algal growth. The growth perhaps is not completely realized because of high turbidities and consequent low light penetration. Reduction in suspended sediment in this upper tidal stretch would probably result in increased algal activity, but to an unknown degree. No magic number is presently available to indicate what, if any, additional nutrient addition to the Fatuxent estuary could be assimilated without causing secondary problems such as eutrophication.

Water quality changes due to water diversion practices discussed for the Patuxent, indicate a possible salinity change that could upset the habitat and interfere with commercial species. For example, a decrease in fresh water input due to exportations to washington, D.C., could cause an upstream movement of the salt wedge. Research indicates striped bass spawns at the salt-freshwater interface. If the salt-fresin interface is moved to a future upstream poor water quality area or a trunk sewer line outfall area, there may be a damaging effect on striped bass reproduction. A reverse effect, namely a great increase in fresh water input from the Susquehanna basin and/or a great increase in treated sewage water could displace the salt wedge far down-river. Thus if the wedge is moved down to the power plant intake area, bouyant striped bass eggs could be pumped through the plant and be subjected to thermal shock and chlorination. It is not known what effect such treatment would have on egg hatchability; however, present judgment indicates a probable detrimental effect which should be avoided. 

Thermal and chemical pollution from the Pepco pover plant is being documented and a final report is due in the summer of 1968. Fish and crab kills have been recorded around the outfall structure with 40,000 blue crabs the largest kill noted to date. Iaboratory and field data indicate little or no survival of most entrained organisms (algae, zooplankton, etc.) pumped through the power plant. In addition a serious green oyster problem existed above the Benedict Bridge after the plant began operations. The greening was due to an increase in copper uptake. It is believed the copper came from corroding condeaser tubes from the power plant. Condenser tubes have been replaced by a more corrosion resistant alloy and the green oyster problem seems to be diminishing. New state water quality standards should help reduce the thermal loading problems in the Patuxent.

Additional industrial development that requires process water would pose a threat to present recreational values and to the commercial seafood industry. Deep water port development with threat of oil spillage, etc. from ocean going vessels would also interfere with maximum development and utilization of the tidal Patuxent as a seafood producing estuary and as a recreational area.

\section{Recommendations}

Iack of nitrient and primary production data from the Patuxent between Lower Marlboro and Hill's Bridge make it extremely difficult to predict what the effect of additional treated sewate waste would have on the system. Present oxygen sags in the Hill's Bridge area and periodic oxygen loss in the deep water portions below Benedict Briage dictate we take a conservative stand with regard to additional nutrient addition. Pritchard has indicated a doubling of nutrient levels in the upper Chesapeake Bay system would result in eutrophication of the upper system. The upper Patuxent system (above Benedict Bridge) is probaily analogous to the upper Bay area and could probably assimilate an additional quantity of nutrients. Our chief responsibility, however, is to determine how much additional fertilization is needed to reach maximum biological production with regard to recreationally and commercially important species. Over-fertilization, of course, can bring the system beyond a critical but unknwon threshold point and result in eutrophication problems. It is recommended that additional research be conducted especially in the estuary segment between Lower liamlboro and Hill's Bridge. The possibility of running a trunk sewer line into the lower Patuxent where a large volume of dilution water is available would reduce the problem of oxygen sags throughout a cross-sectional area such as exists in the upriver non-tidal portions. Such downriver releases would seem to interfere less with anadromous fish migration, but at the same time risk contaninating sheelfish beds and would also increase oxygen depletion in the channel segments.

Obviously, tertiary sewage treatment at the source, with organic and nutrient reduction, would eliminate problems of oxygen depletion and eutrophication. If it can not be economically justified, such treatment will be deferred and treated sewage will be released, it seems, into selected aquatic sites in the Fatuxent or the Bay. 

In order to make necessary predictive statements concerning the effects of environmental changes on the Patuxent estuary, the following pieces of information will be required:

1. Salinity model

2. Dissolved oxygen model

3. Nutrient - primary productivity relationships

4. Energy flow and food chain relationships in the system necessary for optimum yield of commercial and recreational species.

A statement by Cronin concerning the conditions of the Chesapeake Bay system is pertinent with regard to our problems on the Patuxent:

"We do not now know enough about the ecological requiremerts of any of the species named above to gride effective protection and optimal management. The biological community is, however, well suited to the natural conditions of the bay and shows many impressive adaptations to those conditions.

"Our deep concern with, and fear of, changes in the estuary and other environments seem to me to arise from our knowledge on several points:

"1. Fvery such change is probably destructive to the efficiency of the system, at least initially.

"2. Such destruction may be irreversible and may involve a critical link in the food chain or community structure.

13. We cannot yet make reascnable predictions of the effects of such changes in time to guide and control decisions."

In overview, it would seem the Patuxent corridor from Hill's Bridge to Drum Point has more value from a long term aspect as a recreational and residential region. The Vashington-Ealtimore industrial - office complex needs a nearby quality environment. The Patuxent corridor can provide for this need, especially if a high speed transport system were incorporated into regional planning. 



\section{Publications and Reports Used in Freparation of This Peport}

Allison, James I. 1967. The Patuxent River. Physical Chemical and Bacteriological Water Quality. Report No. 1. January 1961 February 1963. State of Maryland, Dept. of Water Resources.

Anderson, Richard R. 1966. Plant ecology of the upper Patuxent estuary with special reference to the effect of thermal pollution on macrophytes. Ph. D. dissertation, Botany Dept., University of Maryland.

Anderson, R. R., C. C. Phillip, R. D. Rappleye and R. G. Brown. 1965. Checklist of vascular aquatic plants in the upper Patuxent estuary. University of ilaryland, Natural Resources Institute, Ref. No. 65-50.

Anon. 1966. Report on the Patuxent River basin. Dept. of Environmental Engineering Science. The Johns Hopisins University.

Anon. 1967. ilater quality and pollution control study. Patuxent River basin. CB-SRBP Working Document No. 15. Federal Tater Pollution Control Administration. Middle Atlantic Region.

Beavin, G. Francis. 1960. Temperature and saiinity of surface water at Solomins, Maryland. Ches. Sci. I(I): 2-1I.

Bishop, John W. 1967. Feeding rates of the ctenophore, Mnemiopsis leidyi. Ches. Sci. 8(4): 259-26I.

Cory, Robert L. 1967. Epifauna of the Patuxent River estuary, Maryland, for 1963 and 1964. Ches. Sci. 8(2): 71-89:

Cory, Robert I. and Jon w. Nauman. 1967. Temperature and water quality conditions for the period July 1963 to December 1965, Patuxent River estuary. J. S. Dept. of Interior, Geological Survey. Open-file report.

Cronin, I. Eugene. 1967. The condition of the Chesapeake Bay. Trans. 32nd N. Amer. Vildlf. and Nat. Res. Conf., pp 137-150.

Elser, Harold J. 1963. Patuxent River creel census, summer of 1963. U. of Md. Nat. Res. Inst., Ref. No., 63-53.

Heidel, S. G. and W. W. Frenier. 1965. Chemical quality of water and trace elements in the Patuxent River basin. ild. Geol. Survey. Rept. of Investigations, No. 1 .

Heinle, Donald R. 1966. Production of a colanoid ccpepod, Acartia tonsa. in the Patuxent River estuary. Ches. Sci. 7(2): 59-74.

Hollis, E. H. 1967. Fishery resources of the Patuxent River system. Dept. of Ches. Bay Affairs, Annapolis, Hd. (13 pp. mimeo). 

Fiansueti, Romeo J. 1961. Wovements, reproduction, and mortality of the white perch, Roccus americanus, in the Patuxent estuary, Maryland. Ches. Sci. $2(\overline{3-4): 142-205}$.

Mihursky, J. A. 1963. Patuxent River estuary study with special reference to the effects of heated steam electric station discharge water on estuarine ecology. U. of Md. Nat. Res. Inst., Ref. No. 63-63.

Mihursky, J. A. and D. A. Flemer. 1967. The effects of thermal loading and water quality on estuarine primary production. U. of Mid. Nat. Res. Inst. Proposal for Research. Submitted to Office of water Resources Research.

Mihursky, J. A., C. I. Gibson, V. S. Kennedy and W. Roosenburg. 1966。 Patuxent Thermal Study. U. of Mid. Nat. Res. Inst., Ref. No. 66-47.

Mihursky, J.A. and A. J. McErlean. 1964. Fishes collected by haul seine in the Patuxent River during the period August 1962 to Feoruary 1964. U. of ild. Nat. Res. Inst., Ref. No. 64-32.

Mihursky, J.A, and A. J. McErlean. 1964. Otter trawl collections made in the Patuxent River during the period June 1962 to August 1964. U. of Mid. Nat. Res. Inst., Ref. No. 64-59.

Mihursky, J.A., A. J. Mctrlean and S. S. Herman, 1967. Cocperative zooplankton investigations in the Patuxent River estuary during the period July 1963 to February 1965. J. of Md. Nà. Res. Inst., Ref. No. 67-59.

Mihursky, J. A., A. J. McErlean, H. T. Pfitzenmeyer and K. Drobeck. 1964. Hydraulic dredge collections made in the Patuxent River during the period June 1964 to May 1964. U. of Mid. Nat. Res. Inst., Ref. No. 64-7.

Mihursky, J. A., A. J. McErlean, W. Roosenburg, V. S. Kennedy. 1967. Patuxent thermal studies. U. of iud. Nat. Res. Inst., Ref. No. 67-61.

Mihursky, J. A., A. J. McErlean, W. Roosenburg, V. S. Kennedy and C。I. Gibson. 1967. Fatuxent thermal studies. U. of Md. Nat. Res. Inst., Ref. No. 67-13.

Stottlemyer, J. R. 1964. Flant nutrients and primary production in the Patuxent River estuary. U. of Md. MoS. Thesis.

Stross, R. G. and J. R. Stottlemyer. 1965. Primary production in the Patuxent River. Ches. Sci. 6: 125-140.

Wolman, A., A. Geyer and B. E. Beavin. 1961. Patuxent Regional Sewage Report. Md. Dept. of Health. 





\section{Appendix IV}

Fishery Resources of the

Patuxent River System

Edgar H. Hollis

Department of Chesapeake Bay Affairs

Prepared for Use by the Patuxent Technical Task

Force Committee

November, 1967 

The fishery resources of the Patuxent River have been recognized in the past for having supported sizable fisheries of fish, crabs, oysters, and soft clams. Commercial harvests of these species still make a substantial contribution to the economies of Calvert and St. Mary's Counties as well as to parts of Charles and Anne Arundel Counties. In addition, sport fishing has expanded throughout the basin and within recent years the water and its fishery resources have taken on new and increasing economic and sociological values as these resources are being used in increasing amounts for self-harvest and recreation within the river system. It is now recognized that the range of many of the species produced or nurtured in the river system extends into the Bay and even to wide areas of the Atlantic coast.

The fish, crabs, oysters, and clams trat abound in this river system are affected by many factors, one of the most important of which is water quality. Although the estuary provides the area of most abundant harvest, many of the estuarine species can be profoundly affected by the ecology in the river above and by factors that may originate anywhere within the 100 mile expanse of the system.

\section{OYSTERS}

Oysters occur naturally in the Patuxent River in the lower twentyone and one-half miles of the estuary, or to a point about two and onehalf miles above the Benedict Bridge. In this area, 13,369 acres have been charted as natural oyster bars. In addition, about 1,435 acres have been leased from the State for private oyster cultivation by approximately 140 individuals making a total of 14,804 acres out of the 22,725 acres in this stretch recognized for oyster production.

Historical statistics for river areas appear not to be available, but recent statistics for the Patuxent show that this area is producing between 40,000 to 86,000 bushels of oysters a year which represents from 248,000 to 534,060 pounds of hign quality protein food with a dockside value as high as $\$ 366,000$. Current state-wide oyster production, although higher than the recent past, is still only about a fifth of the historical high for the state recorded for 1884-35, and it might be assumed that the Patuxent oyster production parallels the historical trend. It might also be postulated that the Patuxent has a potential, with cultivation and management, far exceeding historical high figures and values in oyster production. Were the 14,804 acres now reserved for oyster production to yield 300 bushels per acre (a factor of only 1/10 of some areas of record), production would be $4,441,200$ bushels and that would yield $26,647,200$ pounds of food. 

The soft clarn fishery in Maryland is a relatively new industry having its beginning with the perfection of a hydraulic dredge which was first used commercially in 1952 and first employed in the Patuxent in 1954. In the Patuxent, soft clams occur over much the same range as oysters and are commercially abundant in many areas from Long Point down the estuary over a linear distance of about 18 miles. Adequate survey information for the ertire river is not available but Manning (1957) esiimated that Calvert County had 12,0010 acres of actual or potential clam-producing areas. If we assume St. Mary's County has a similar area potentially productive for clams, the total acreage for clam production in the river would approximate 24,000 acres.

Current production of clams from the Patuxent River (1965) is about 16,500 bushels yielding nearly 200,000 pounds of meat worth about 42,000. Historical (yield) figures are not available for the entire river, but production in Calvert County has been as high as 23,000 bushels in 1960 and it is ressonable to assume that St. Mary's County production might be equally as higi for a total yield of 46,000 bushels or 452,000 pounds of clams.

The clam resources in Maryland are generally regarded as under exploited since higher production without damage to the resource is possible if a strong (year-round) market demand could be developed. The present fishery for clams is now geared to curtailed production, the clam dredgers being restricted by law to a daily limit of 40 bushels and oiten restricting their catch to less than this to fill "orders".

\section{CRABS}

The Patuxent Estuary provides an important habitat for crabs which migrates to the area as juveniles where they feed and grow before completing their life cycle at the mouth of the Bay.

Although the statistics for crabs show vacillation in harvest, the lower Patuxent traditionally enjoys a reputation for good supply. Statistics for 1965 show that 80,000 pounds were harvested in this area with a dockside value of about $\$ 9,000$. In addition to this quantity, large numbers of crabs are known to be taken by recreational fishermen in the area.

In addition to the direct harvest of crabs, it must be recognized that this species also is an important food organism for commercially valuable fish. Although crabs can adapt to many adverse conditions and can sense and migrate from some adverse conditions, they are known to be highly sensitive to organic pesticides. 



\section{FISH}

The Patuxent River Basin supports populations of approximately 160 species of fish. Some spend their entire life cycle within the river. Others utilize various levels of the river for spaming and nursery areas. Still others invade the river simply on feeding migrations.

Of the approximately 160 epecies of fish recorded in the Paturent River system, ore-third are sufficiently abundant to contribute substantjally to the fish population of the river. Most important economically are the anadromous and semi-anadromous species such as the striped bass, shad, whiteperch, hickory shad, yellow perch, winter flounder and river herring which utilize the river as spawning and nursery grounds and to various degrees as adult habitat. These species contribute heavily to the commercial and sport fisheries.

Another group of economically important species harvested in the Patuxent River are the summer migrants which spaw and winter outside of the Chesapeake Bay but utilize the estuary for nursery areas and summer feeding grounds. Included in this group are the spot, croaker, silver perch, seatrout, and drums.

A third segment of the fish population, which is vital to the predatory fishes but orten averlooked by the fishermen and others are the numerous species of small, inconspicuous fishes which swarm throughout the Patuxent system providing food for many commercial and sport fishes. Most of these are incigenous to the river system.

Statistics of catch for the Patuxent system are not generally available. Those that have been assembled show that the annual commercial production relies upon about 24 species whose catches have aggregated from about 100,000 pounds $(1965)$ to over 800,000 pounds (1951). Dockside value of the incomplete catch figures for commercial fish production suggest a direct income of up to $\$ 120,000$ a year from this harvest.

In addition to the commercial production of finfish, we must recognize that increasing numbers of fish and values are derived from an ever expanding sport fishery that now extends throughout the basin and throughout the year. Also, the river affords spawning and nursery areas and forage for species that migrate within the Bay and, in the ocean range over much of the Atlantic Coast where they are utilized in sport and commercial harvests.

\section{RECREATION}

The Patuxent is serving recreational demands for boating, fishing, swimming, picnicking, and a setting for second homes. 


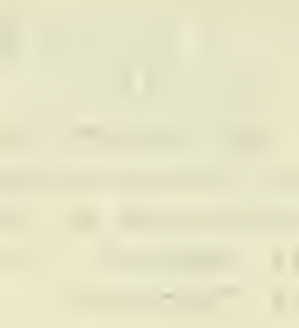


A number of stlidies of sportfishing have been conducted in the lower Patuxent. The data developed by Elser (1963) and Shearer et.al. (1962) provides information on how the estuary meets the needs for recreational fishing. It is estimated that more than 71,000 trips were made into the estuary during 1963. Fishermen caught 278,000 pounds of fish and 42,800 pounds of crabs. Their expenditures approached $\$ 500,000$, not counting their irvestment in boats, permanent tackle and similar appertenances.

General recreational fishing studies show that we can expect a five to seven percent ennual increase in recreaticnal use of such water areas in the future. On this basis, it can be predicted that by 1980 the lower Patuxent will support more than 200,000 fishing trips per year with expenditures well over a million dollars.

Recreational fishermen are innovative and are constantly devising new methods to take additional species for their enjoyment. This attracts increasing numbers of people to the fishing fraternity. Bow and arrow fishing and spear fishing are being developed and publicized with species such as skate, rays and carp are taking on new importance as quarry. The development of new artificial lures together with easily manipulated light tackle has brought shad and herring to increased importance among sport fishermen. Scuba diving has attracted a large number of participants and divers are now engaging in the recreational harvesting of not only fish, but also oysters and clams. The recreational harvest of shellfish by increasing numbers of visitors to the area re-emphasizes the need for maintaining high water quality wherever shellfish might be taken.

The recreational potential of the Patuxent estuary and up-basin fluvial streams is just developing for the recreational boater. At the present time about 22 marine facilities exist within the Patuxent system between Solomon Island and Benedict, while several small boat rental establishments exist above this point. The 22 facilities offer slips and monrings to accommodate 895 boats, furnish launching areas for small boats and offer small boat rentals. The Solomons area has excellent boat building and boat repair facilities. Although recreational boating in the entire State of Maryland has increased (from about 29,000 pleasure boats to the present 68,000 ) since the $1940^{\prime} \mathrm{s}$, the Patuxent now harbors only approximately 2,700 of the registered boats. Expansion in this recreational sector will increase with the build-up of recreational homes, the development of resorts and the improvement of road systems.

The areas immediately adjacent to the Iower Patuxent are becoming increasingly attractive for permanent and second hones of many employed in the Washington area. As the roads have improved, many have established home - sites adjacent to the Patuxent that they first developed for summer homes with the ultimate objective of retiring in these areas where they can enjoy the natural environmental qualities of the area and still be within easy commuting distance of Baltimore and Vashington. This trend in development will likely continue and increase and broaden the tax base if the basic qualities now found can be maintained. 



\section{NEEDS FOR WATER QUALITY}

Cominon to all fish species in the river is the need for satisfactory environmental conditions, particularly good water quality and sufficient flow.

Particularly vilnerable to poor water quality are the eggs, larvae, and young which in many species are restricted to the fresh and slightly brackish upper reaches of the Patuxent River where habitat acreage is very limited and any lethal conditions would quickly decimate the population. Such valuable species as striped bass, white perch, yellow perch, and shad, would be hardest hit by poor quality of the fresh water inflow.

Protection of the fish and other aquatic organisms in the Patuxent River requires elimination and prevention of any contamination which would cause mortalities during any life history phase from egg to adult of fishes or supporting organisms. Equally, if not more important, is the prevention of sublethal conditions such as turbidity and siltation, pesticides and other contaminants which are not of sufficient concentration at any particular time to cause mortalities, but which over extended periods degrade and poison the habitat or the occupants. These condjtions either eliminate fish altogether, or as usually happens, favor the propagation of undesirable species such as carp, suckers and mud shad.

\section{PHYSICAI FACTORS ATTENDANT TO FLOW}

Relatively stable inflow volume is desirable at all times and is necessary for successful reproduction of many species. Severe fluctuations in water level, such as occurs in the Susquehanna River below Conowingo Dam, results in exposure to dessication of attached fish eggs during periods of low flow and stranding and suffocation of adult anadromous fish during the spawning run.

Another attendant problem of oscillation in water flow involves salinity stability. Distribution of many estuarine animals and plants is regulated by salt content of the water and any profound change in salinity in any particular area results in a change of organism types in that area. Motile animals such as fish and craos can move as the salinity changes, though early life history stages may perish. However, sessile animals such as the highly important oysters and clams cannot relocate and exposure to fresh waters for several weeks results in serious mortalities.

A third deleterious aspect of fluctuating water levels is temperature variation of the inflow, particularly that from impoundment release. Water temperature regulates spawning activities of most fishes and determines the success of hatching and survival of the young. Water surges of different temperatures, such as might occur from dam discharges at different levels could initiate spawning activities prematurely resulting in death of eggs and larvae. 

An abundance of dissolved oxpgen is required for the sustenance of all of the desirable biota of the river and this need is demanded throughout the course of the river. Dissolved oxygen may not be present from sub-surface discharges in impoundnents. It can be reduced by the introduction of sewage, the development and disintegration of plankton blooms, fish kills, rooted aquatic vegetation and even by the introduction of organic laden surface drainage from sanitary land fills and can be changed and reduced by changes in $\mathrm{PH}$.

Nutrients, particularly nitrates and phosphates, are as essential to fish production as to farm production. Nutrients are utilized by water plants, particularly the microscopic a?.gaes which form the base of a food chain extending through zooplankton, forage fishes and food fishes, culminating with consumption by man.

Though vital to the aquatic community as a primary source of energy, nutrients in excess are extremely detrimental and become a form of pollution. Excessive enrichment is generally attributable to man - the major source emanating from domestic and industrial effluents augmented by runnoff from fertilized agricultural lands. An important point to remember is that nitrates and phosphates are not entirely eliminated by even the best and most thorough forms of sewage treatment.

Eutrophication* is generally characterized, particularly during warm months, by dense growths of aquatic plants - both floating algae and rooted water plants. These dense growths are unsightly and frequently interfere with fishing, boating and other water oriented recreation. Furthermore, death and decay of the algae and plants results in oxygen depletion and fish and crab mortalities.

These manifestations of excess nutrients reduce property and recreational values and accme considerable expense to shore owners and governmental agencies for removal or treatment. Control frequently takes the form of herbicides resulting in further contamination of the water and endangerment to aquatic resources.

\section{CHEMICAL POLLUTION}

The necessity of preventing the myriad types and sources of industrial pollution from entering our water bodies is widely recognized. However, attention needs to be directed toward long term effects of the burgeoning use and proliferation of pesticide formulations.

Chemicals now registered for agricultural use include approximately 900 toxicants compounded into 60,000 formulations. Home owners, governmental (pest control) agencies and agriculture interests apply numercus pesticides and herbicides which eventually enter the main river. Fish populations can be severely damaged by these toxicants. However, much more vulnerable because of close taxanomic relationship to the target pests, are the crustacean type animals ranging from microscopic copepods utilizes as fish food to the highly valuable blue crab used as human food.

* The state of having an excess enrichment of nutrients often associated with a shallow, slow flowing water body and depleted oxygen level. 

Experimentation hes shown that minute concentrations such as one-half part per billion are toxic to these animals. One such test of heptachlor on adult shrimp produced 50 percent mortality and paralyses within 48 hours at a concentration of 0.3 - 0.4 parts per billion. Another phenomenon accentuating the dangers of water born toxicants is a process known as biological magnification. This involves accumulation and retention of toxicants by individual organisms and a transfer of these deposits to any organism that feeds upon it. The concentration of the chemical in the water may be infinitesimal, but the concentration attained through the food chain may severly harm higher organisms. A classic example involves the fish eating, bald eagle. Severely curtailed reporduction of this species during recent years is believed attributable to high concentrations of DDT and derivatives in body tissues.

Filter feeders such as oysters and clams are particularly adept at concentrating contaminants. Oysters, for example, have been found to contain 170,000 times the zinc and 70,000 times the DDT present in the surrounding water.

In considering the need for the maintenance of high water quality required by fish, crabs, oysters and clams and the biota needed for their sustenance and growth, it is highly important to recognize that some of the prevailing water quality standards and parameters used in measurement have little biological significance. Values expressed as averages and means may very well represent parameters satisfactory to the organisms of the river. It should be recognized and emphasized however, that organisms have rather critical tolerances which when exceeded for only a short time or even momentary can be lethal. It should also be recognized that adverse conditions are most likely to affect early life history stages, which are microscopic in size, and the effects are most unlikely to be detected at the time of the occurrence.

One of the most critical requirements for both oysters and clams is that the waters from which they are harvested be free from contaminants that may be injurious to human health. Both oysters and clams are filter feeders and thus tend to accumulate bacteria and many of the physically and biologically bound residues that are in their immediate growing area. As a consequence, the National Shellfish Sanitation Program, a cooperative control program of the states and the U. S. Public Health Service will not sanction the harvest of either clams on oysters from waters having a median coliform MPN of more than $70 / 100 \mathrm{ml}$. Metalic salts of lead, copper, zinc and organic pesticides are also known to accumulate in shellfish without apparent harm to them but at levels not tolerated in human food.

The Patuxent estuary is still considered prime shellfish producing waters and has an outstanding reputation for producing high quality "fat oysters". Only one small area in the whole estuary is restricted for the harvest of shellfish because of high bacterial counts. This area is the Solomons Island Harbor area including Back, Mill and St. Johns Creeks. Five (5) acres of charted oyster bars are restricted. 

Buzzell, R. D. and E. T. Walker 1954. A study of sport fishing in tidewater Maryland. Md. Dept. Research \& Educ., Resource Study Rept. (4), Pt. I: 1-I4, Pt. II: 1-6.

Crossley, S - D Survey, Inc. 1956. National survey of hunters and fishermen, supplemental state report。 Crossley, S - D Surveys, Inc. New York, $N, Y$.

Elser, H. J. 1963. Patuxent River creel census summer of 1963. Natural Resources Inst., U. of Md. Ref. No. 63-53: 1-13 plus Graphs and Tables.

Hammer, R. C., H. A. hensel and R. E. Tiller 1948. Maryland commercial fisheries statistics 1944-1945. Chesapeake Biol. Lab. (69): 1-48。

Hensel, H. A. and R. E. Tiller 1952. Maryland commercial fisheries statistics 1946-1950. Chesapeake Biol. Lab. (94): 1-105.

Hensel H. A. and R. E. Tiller 1954。 Maryl and commercial fisheries statistics 1951-1952. Chesapeake Biol. Lab. (99): 1-28.

Manning, J. F. 1957. The Maryland soft shell clam industry and its effects on tidewater resources. Md. Dept. Research and Educ., Resource Study Rept. (II): 1-25.

Shearer, L. T., D. E. Ritchie, Jr. and C. M. Frisbie 1962. Sport fishing survey in 1960 of the lower Patuxent estuary and the 1958 year class of striped bass. Chesapeake Sci. 3 (1): 1-17.

U. S. Bureau of Sport Fisheries and Wildlife 1962. Sport fishing today and tomorrow. Outdoor Recreation Resources Review Comm. $127 \mathrm{pp}$.

U. S. Bureau of Sport Fisheries and Wildlife 1966. 1965 National survey of fishing and hunting. Bur. Sport Fish. and rilildl. Research Publ. 27, $76 \mathrm{p}$. 



APPENDIX V

SEDTMENT AND EROSION

CONTROL IN

MONTGONARY COUNTY,

WARYIAND 

SUBDIVISION REGULATIONS

FOR THE

MARYLAND-WASHTIGTON

REGIONAL DISTRICT.

WITHIN

MONTGOMERY COUNTY

Maryland-National Capital

Park and Planning Commission

Sec. $104-24$

(i) Sediment Control (adopted 6/27/67). The approval of all preliminary plans and extensions of previously approved plans shall include provisions for erosion and sediment control, in accordance with the Montgomery County Sediment Control Program, adopted by the Jounty Council June $29,1965$.

(1) The Board, in its consideration of each preliminary plan or extension of previously approved plan, shall condition its approval upon the execution by the subdivider of erosion and sediment control measures to be specified by the Board after receiving recommendations from the Montgomery Soil Conservation District.

(2) One copy of each approved preliminary plan or extension of previously approved plan shall be referred to the Montgoinery Soil conservation District for review and recommendation as to adequate erosion and sediment control measures to prevent damage to other properties.

(3) The installation and maintenance of the specified erosion and sediment control measures shall be accomplished in accordance with the procedures for Public Works Agreement as specified in Sec. 104-26 (g) and in accordance with standards and specifications on file with the Montgomery Soil Conservation District.

(4) Permits for clearing and grading prior to the recordation of plats shall be obtained from the Department of Public Torks subject to the granting of temporary easements and other conditions deemed necessary by the Department in order to inspect and enforce the performance of the specified erosion and sediment control measures provided for in subsection (I) above.

(5) In the event the subdivider proceeds to clear and grade prior to recording of plants, without satisfying the conditions specified under Sec. 4, the Board may revoke the approval of the preliminary plan or extension of previously approved plan. 



\section{SEDIIENT CONTROL}

\section{PROGRAM}

MONTGOIYERY COUNTY, MARYLAND

Maryland-National Capital

Park and Planning Commission

March 1967 



\section{PROCEDURES FOR INCORPORATING \\ EROSION AND SEDINENT CONTROL \\ IN SUBDIVISION PLANS}

Under this sediment control program, the following procedures are provided to assist landowners, developers, and engineers in the inclusion of required erosion and sediment control measures in the planning and construction of subdivisions:

\section{Pre-application Stage}

Optional discussions between developers and the various county agencies are provided for in Section 104-22 of the Subdivision Regulations for Montgomery County。 During these discussions consultive technical assistance from the Soil Conservation District, the Department of Public Works, and the Planning Board is available to landowners, builders, developers, and their engineers.

The assistance of the Soil Conservation District is available to owners and developers who become Soil Conservation District Cooperators under informal Landowner-District cooperative Agreements,

\section{Preliminary Subdivision Plan Stage}

A. Under existing procedures, developers submit plans to the Maryland National Capital Park and Planning Commission, where they are:

1. Reviewed for conformance with existing ordinances, master plans,etc。

2. Referred to various agencies for compliance with their regulations and specifications.

The Commission staff will determine on the basis of size, topography, erosion hazards, and other factors relating to sedimentation which plans will be submitted to the Soil Conservation District for review of erosion and sediment control measures. It so indicates on the copies referred to other agencies.

The Subdivision Review Committee, composed of staff members of the reviewing agencies, resolves any differences which may arise. Soil Conservation District Technical Assistance in developing needed erosion and sediment control measures will also be furnished on request at this stage.

B. After all reviews are completed, the planning staff submits the plan to the Montgomery County Planning Board with recommendations. 

E. After the preliminary subdivision plars are approved by the Planning Board, the planned erosion and sediment control practices are incorporated into the Public Torks Improvement Agreement under Section 104-26 of the Subdivision Regulations for Montgomery County.

B. Upon receipt of the Department of Public Torks' acceptance of the Public fiorks Improvement Agreement, the Naryland National Capital Park and Planning Commission records the subdivision Plat.

\section{Construction Permit Application Stage}

The Department of Public Works reviews the construction permit application plans for conformance with sediment control and other provisions of the approved preliminary plans.

\section{Construction Stage}

A Consultive technical assistance in establishing the planned erosion and sediment control measures is furnished by the soil Conservation District on request of the builders, developers, and their engineers, consistent with current operating policies and available resources at the time the work is to be done.

B. The Department of Public Forks enforces compliance with the approved plans.

\section{EVALUATION AND IMPROVEMENT OF PROGRAM}

Agencies and departments of county government operating in and having jurisdiction in the county will hold at least one annual conference on the progress of this sediment control program. At this conference, the observations and experience of the agencies and the builders associations will be reviewed and needed program improvement discussed.

At the same time, federal and state agencies will be invited to participate in a review of the following:

(1) Hydrologic and Sediment Research Project on North Branch Rock Creek and Northwest Branch Anacostia. (USGS, USDA-ARS, SCS, Md. Geol. Survey, Md. Dept. of Water Resources)

(2) Sedimentation Surveys of Rock Creek Dams \#I and \#5 being done by USDA Soil Conservation Service.

(3) Sediment Trap Efficiency Study being done by USDA Soil Conservation Service and U.S. Geological Survey on Dam Site \#I on Rock Creek. 



\section{COUNTY COUNCIL \\ MONTGONERY COUNTY, MARYLAND}

WHEREAS, The people of the county have recognized the problems of soil erosion by creating the Montgomery Soil Conservation District, now operating a voluntary conservation program in the open areas of the county, and

WHEREAS, The shifting of land use in Montgomery County from agriculture to urban and suburban development has substantially increased silt and sediment problems on the lands and in the streams and lakes in the county and in the Potomac River, and

WHEREAS, Sediment from developments has been declared a pollutant within the meaning of Art. 96A Ann. Code of Maryland $1957 \mathrm{Ch} .73$, Laws of M.d. 1964 entitled, "Trater Resources", (f. legal opinion by the office of the Attorney Ceneral of Maryland), and

WHFREA, Property owners suffering unreasonable damage from sediment deposition or flooding of property at downstream sites as a result of distrubance of watershed areas upstream often must seek protection by the courts against such damages,

NOW THEREFORE BE IT RESOIVED:

1. That it is the policy of Nontgomery County, Maryland, to provide for control of soil erosion particularly in the urbanizing areas of the county by the adoption and implementation of a Sediment Control Program for developments on the public and pirivate lands of the county.

2. That the various departments and branches of the county government are directed to develop folicies and procedures and to implement this program and the Builders Advisory Committee is requested to work with the county agencies and the builders to assist in this work.

3. That the landowners and developers of Montgomery County are urged to cooperate in this program and to abide by its procedures and regulations. 



\section{TIASHINGTON SUBUREAN SANITARY COMMISSTON}

WHEREAS, in rural areas undergoing extensive ferning operations, soil erosion has been a serious problem, and

WHEREAS, the INontgomery Soil Conservation District, operating on a voluntary conservation program in the rural areas of the County, was formed to provide assistance and direction to the local residents in adopting techniques that would reduce the soil erosion, and

WHEREAS, this Commission has been contributing regular annual payments for soil control measures and soil conservation work in the Patuxent River Basin to the Maryland Association of Soil Conservation Districts, Inc., in an amount totalling $\$ 35,000$ since 1948 as support for erosion control work in the Patuxent River Basin, and

WHEREAS, the rate of change from agricu?ture to suburban development in the Patuxent River Basin is increasing, and

WHEREAS, suburban development frequently involves the removal of forests and agricultural grass lands thereby substantially increasing silt and sediment problems during the construction period, and

WHEREAS, the Commission is desirous of seeking improvements in silt control from such suburban construction operations, especially in the Patuxent River Basin, and

WHEREAS, the Commission, on July 8, 1965, agreed to participate financially in the amount of $\$ 7,500$ annually, subject to annual review, for a proposed ten-year study of silt production by subdivision development and methods of control for such silt production,

NOW THEREFORE BE IT RESOLVED THAT THE COMMISSION:

1. Endorses a program to provide data on the amount of silt produced by subdivision development with an evaluation of the economic impact of this silt on the area and a study of the effectiveness of control techniques.

2. Requests the United States Geological Survey and the United States Department of Agriculture to provide the necessary additional financing and to conduct this study providing the Commission periodic reports on the progress of the work and an annual report so that the Commission can make an advance evaluation on its continued annual participation in the study.

3. Requests the agencies making the study to expand them to include the Patuxent watershed.

4. Will cooperate with the agencies conducting this study to the maximum possible extent so that the necessary study information can be secured. 

WHEREAS, The people of the county have recognized the problems of soil erosion by creating the Montgomery Soil Conservation District, now operating a voluntay conservation program in the open areas of the county, and

WHFREAS, The shifting of land use in Montzomery county from agriculture to urban and suburban development has substantially increased silt and sedinent problems on the lands and in the streams and lakes in the county and in the Potomac River, and

WHEREAS, Sediment from developments has been declared a pollutant within the meaning of Art, 96A Ann.Code of Maryland $1957 \mathrm{Ch} .73$, Laws of Md. 1964 entitled, "Titater Resources", (a legal opinion by the office of the Attorney General of Maryland), and

WHEREAS, Property owners suffering unreasonable damage from sediment deposition or flooding of property at downstream sites as a result of disturbance of watershed areas upstream often must seek protection by the courts against such damages,

\section{NOW THEREFORE BE IT RESOLVED:}

I. That it is the policy of the District to provide for control of soil erosion in the county by the adoption and implementation of a sediment control program for public and private lands undergoing changes from agricultural to other uses within the county.

2. That the District will cooperate with the various departments and branches of the County Government and other agencies to develop policies and procedures to implement this program.

3. That the District will furnish consultive assistance to develop conservation plans and establish conservation measures for lands undergoing development to the landowners, developers and the public agencies concerned, consistent with current operating policies and available resources at the time work is to be done.

The cooperation of Montgomery County landowners, developers, and the public agencies concerned is solicited to further this program. 

WHEREAS, The people of the county have recognized the problems of soil erosion by creating the Montgomery Soil Conservation District, now operating a voluntary conservation program in the open areas of the county, and

WHEREAS, The shifting of land use in Montgomery County from agriculture to urban and suburban development has substantially increased silt and sediment problems on the lands and in the streams and lakes in the county and in the Potomac River, and

WHEREAS, Sediment from developments has been declared a pollutant within the meaning of Art, 96A Ann. Code of Maryland $1957 \mathrm{Ch} .73$, Laws of Md. 1964 entitled, "Water Resources", (a legal opinion by the office of the Attorney General of Maryland), and

WHEREAS, Property owners surfering unreasonable damage from sediment deposition or flooding or property at downstream sites as a result of disturbance of watershed areas upstream often must seek protection by the courts against such damages,

NON THEREFORE BE IT RESOLVED:

1. That the Commission endorses and supports the County Sediment Control Program.

2. That it is the policy of the Commission and the Planning Board to provide for control of soil erosion particularly in the urbanizing areas of the county and resulting transported sediments, through its exercise of the review and approval authority for subdivision developments.

3. That the same policy shall be implemented through the Commission's Park Department in its development and maintenance of park lands, recreation sites, etc.

4. That it shall be the policy of the Commission and the Planning Board to seek comments and/or recommendations from the Montgomery Soil Conservation District with respect to processing of such preliminary subdivision plans as in the Board's judgment will require soil erosion measures to be carried out by public and private interests during the development of such subdivisions. 


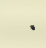




APPENDIX VI

STATE AGENCY AND

REGIONAL PLANNING

AGENCY

COMMENTS 

DEPARTIENT OF THE ARIY

Headquarters Fort George G. Meade

Fort George G. Meade, Maryland 20755

AHBMEN $-U$

Nay 24, 1968

Mr. James J. O'Donnell, Director

State of Maryland

Planning Department

State Office Building

301 W. Preston Street

Baltimore, Maryland 21201

Dear Mr. O'Donnell:

Reference is made to letter dated 22 March 1968, from State of Maryland Planning Department to this Headquarters in connection with the formal review and comment on the final draft of the Patuxent Report.

Comments and/or recommendations on the aforementioned report are as follows:

a. Fort George G. Meade should be represented in the event a Patuxent Basin Sanitary Advisory Committee is organized. Even though this Headquarters has only a relatively small portion of the basin population, representation is necessary for proper coordination and to insure that programs developed are compatible with Department of Army policy and standards and will best satisfy the needs of Fort Meade.

b. Since the programs developed by the Patuxent Basin Council could possibly involve a joint financial investment by the various counties and Fort Meade, this Headquarters should also be represented on the Patuxent Basin Council. In view of the nature of Department of Army policy and funding programs, it is essential that the Federal Government representatives have a complete awareness of all ineasures recommended by the Patuxent Basin Council that would affect Fort Meade. If this Headquarters is expected to implement such recommendations and agrees to do so, the actual construction work will have to be programmed for funding in the normal manner. Implementation of recommendations would also be contingent on approval by higher Headquarters, the urgency of the work involved, the relative priority within the Departinent of Army program, and availability of funds.

FOR THE COMNANDER:

/s/ Leslie D. Sari

2 LT. INF.

Actg. Asst. Adj. Gen. 

DEPARTMEIT OF CHESAPEAKE BAY AFFATRS

State Office Bui?ding

Annapolis, Maryland 21LO4

April 29, 1968

Mr. James J. O'Donnell, Director

Planning Department

30 ? West Preston Street

Baltimore, Naryland 21201

Dear Mr. ODonnell:

The Report on a Re-Examination of the water and Related Land Resources Problems of the Patuxent River Basin - February 14, 1968 in general concept will serve well to provide giidelines for safeguarding and perhaps enhancing the Patuxent tributary, which is a major component of our Chesapeake Bay system.

In implementing remedial actions, may I suggest that this Department is concerned with and can contribute toward the problem of Control of Erosion and Sedimentation. I will be pleased to designate a representative to serve on the Committee proposed under item 7, page vi of the Report if you so indicate.

We are also concerned with the recommendation $3 c$ (page $v$ ) as it relates to possible future diversions of treated wastes. Should diversion of waste ever appear recessary, within or from the Patuxent system, such action might profoundly affect our programs and we would wish to be included early in any discussions pertaining to diversions.

We are particularly interested in Recommendation 4 (page $v$ ) as it relates to future studies of the estuary. Te hope and believe that the proposed Model of Chesapeake Bay and the attendant study by the Corps of Engineers will be of substantial help in understanding the Patuxent. We are also cognizant that there is a great deal of urgency in solving the problems of this system, and we are particularly concerned for the possible effects of effluents from waste treatment plants now being built in the Western Branch area that are close to the estuary. Because of the urgency for maintaining the Fatuxent, I would urge that immediate attention be given to collecting and analyzing the existing information from previous studies in this system (page 25). The Patuxent has perhaps already received more attention than any other single system in the state. In any future studies in the Patuxent, emphasis should be given to monitoring water quality and changes in the biota with timely reporting so that concerned agencies can make effective use of findings. Although detailed and basic studies of the Patuxent system would not be without merit such studies are bound to be expensive and may not yield sufficient information in time to be of material use. An approach embodying rapid integration of the existing information with a monitoring program and extrapolation of data from ongoing studies of areas with similar problems, such as the San Joaquin studies in California, might well serve us better in time than broad basic research. 

Advances in engineering, as they might be applicable to our Patuxent system, would also appear to be worthy of study and consideration. Provision for lagooning against plant failure is but one device that in some situations promises relief from problems that we have experienced in the past, and I would urge that full study and attention be directed toward seeking other engineering devices to insure preservation of water quality in the Patuxent River system.

$$
\begin{aligned}
& \text { Sincerely yours, } \\
& \text { /s/ Joseph H. Nanning } \\
& \text { Joseph H. Manning } \\
& \text { Director }
\end{aligned}
$$

JHM:bsf 



\title{
Copy
}

\author{
DEPARTMENT OF FORESTS AND PARKS \\ State Office Building \\ Annapolis, Maryland $2 \mathrm{ILO}_{4}$
}

March 28, 1968

Mr. James J. O'Donnell, Director

State Planning Department

301 W. Preston Street

Baltimore, Maryland

Re: Formal Agency Review and Comments on Final

Draft of Patuxent Report

Dear Mr. O'Donnell:

The final draft of the Patuxent River Technical Task Force Report has been reviewed by this agency. In general, the Department concurs with the format, information and recommenations outlined in this report.

May I suggest that the following specific points be considered for inclusion in the final document:

1) More emphasis on the importance of the county's responsibilities in implementing the provisions of the Patuxent Watershed Act. The Watershed Act provides the mechanics under which funds may be applied for and received. The counties must take the initiative to implement the funding.

2) In the Findings and Recomnendations chapter under the section Park Recreational and Open Spaces Requirements and Programs, mention should be made of the proposed lower Patuxent State Park. Initial funding for this park is presently programmed to be included in the 1973 budget. Programs which provide for Federal and State fund assistance for acquisition and development should be emphasized. For example, the Land and Water Conservation Fund Act, the Open Space Program under the Housing and Urban Development Agency, and the Outdoor Recreation Land Loan of 1968. 

3) Other bills recently passed by the legislature which have a direct relationship to any program on the Patuxent River are:

a. Senate Bill \#313. Open Spaces: This proposal would authorize the State Department of Forests and Parks, any county or municipal corporation, and the Maryland-National Capital Park and Planning Commission to acquire or designate interests and rights in real property to provide or preserve permanent open space land.

b. House Bill \#416. Scenic Rivers: This bill would establish a Scenic Rivers Program and a Scenic Rivers Review Board for the State of Maryland.

c. House Bill HLI7. Legislation to authorize the acquisition of land to be preserved as natural areas and to provide for their administration.

Mention of this legislation should be included within the Task Force report.

Participating members of this Department have considered it a privilege to work with the Patuxent Technical Task Force. A wealth of information has been collected and the inter-agency cooperation that has resulted is something for which the state should be proud. Perpetuation of this relationship should continue when recommendations of this report are implemented.

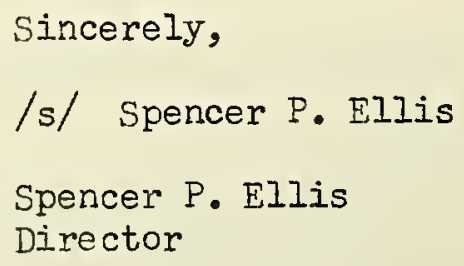

EIH:IC 



\title{
DEPARTIENT OF GARE AND INEAND FISH \\ State Office Building \\ Annapolis, Maryland 21401
}

May 29, 1968

Mr. James J. O'Donnell, Director

Maryland State Planning Department

State Office Building

301 W. Preston Street

Baltimore, Maryland 21201

Dear inr. OPonnell:

In reference to the Final Draft of the Report On A Re-Examination Of The Water And Related Land Resource Problems of the Patuxent River Basin prepared by Malvin E. Scheidt, February 14, 1968, the Maryland Department of Game and Inland Fish has the following comments.

On page $V$, item 4 under Recommendations, the first sentence should include the Maryland Department of Game and Inland Fish. Our inclusion is based on our legislative responsibility for management of waterfowl, Rails, Muskrats, and other marsh related birds and mammals which occur in the estuary portion of the Patuxent River.

With the above inclusion, the Maryland Department of Game and Inland Fish concurs with this report.

\author{
Sincerely yours, \\ /s/ James R. Goldsberry, Jr. \\ James R. Goldsberry, Jr. \\ Technical Advisor
}

JRG/geh

cc: Irr. George B. Shields 

MARYLAIND GEOLOGICAL SURVEY

Latrobe Hall, The Johns Hopkins University

Baltimore, Maryland 21218

April 1, 1968

Mr. James J. O:Donnell, Director

Planning Department

State Office Building

301 . Preston Street

Baltimore, Maryland 21201

Dear Mr. O'Donnell:

Under the provisions of Article 66c of the Annotated Code of Maryland, the Maryland Geological Survey is responsible for the preparation of reports on the extent and character of the State's geology, mineral, and water resources. In response to this charge, the survey has published since 1962 three investigations reporting on the ground-water resources of Anne Arundel County (Bulletin 26), Prince Georges County (Bulletin 29), and Charles County (Bulletin 30); a report discussing the occurrence of ground water in St. Marys and Calvert Counties is currently in preparation.

The data contained in these reports are not fully compatible with some of the findings and recommendations in "Report on a Re-ixamination of the Water and Related Land Resources Problems of the Patuxent River Basin".

Regarding water supply in the Anne Arundel-Prince Georges County area, the "Report" implies that ground water sources have already been exploited to the maximum and, therefore, do not constitute a viable alternative. While it is true that ground-water sources alone cannot supply the quantities of water necessary to meet future demands in the area, it should be explicitly understood that considerable amounts of ground water remain to be exploited. In Anne Arundel and Prince Georges Counties daily ground-water withdrawals total about 30 million gallons. It is estimated, however, that as much as 125 million gallons per day can be pumped from the several aquifers underlying the two Counties without exceeding a "safe yield". In order to approach this amount of withdrawal, it would be necessary to develop a system of properly spaced well fields. To date, cases of ground-water failure in the Coastal Plain can be traced to ill-conceived attempts to withdraw excessively large amounts of water from geographically restricted areas. The cost and feasibility of establishing linear well fields within the proposed park lands surrounding the river and its tributaries should be considered. The compatibility of this 

arrangement has been effectively demonstrated by the City of Salisbury. Ground water thus obtained could be used to supply surrounding consumers and, perhaps, for low flow augmentation.

In several places the "Report" mistakenly assumes that because ground water is withdrawn from a point source (a well), its effects are largely local. Actually, the hydraulic continuity of a deep, artesian aquifer transceno's surficial river boundaries and, clearly, should be managed from a regional point of view. In many instances this includes a major portion of the Coastal Plain.

Because the Maryland Geological Survey is charged with the responsibility of investigating the geology, mineral, and water resources of the State, and since the processes under discussion in the "Report" operate within and are controlled by geohydrologic variables, it would appear logical that the scientists on the Staff of the Survey and the cooperative U. S. Geological Survey personnel may be able to contribute to one or several of the Committees discussed under "Organizational Arrangements". No such suggestion is made in the "Report".

We feel the "Report" is quite meritorious in many respects, but we also feel that it does not adequately take into account the role which ground water plays in the development of the water resources of the Basin and surrounding areas.

Sincerely yours,

/s/ Kenneth $\mathbb{N}$. Weaver

Kenneth $\mathrm{N}$. Weaver

Director

$\mathrm{KNW}: \mathrm{er}$ 



\section{STATE DEPARTMENT OF HEALTH AND DEPARTMENT OF WATER RESOURCES}

\section{ON PATUXENT RIVER BASIN TASK FORCE REPORT}

The Maryland Departments of Health and Water Resources, having been individually represented on the Task Force of the Patuxent River Advisory Committee, take this opportunity to jointly comnent on the findings of the Task Force, as well as to briefly discuss the water pollution control program of the State in the Patuxent River Basin.

Much credit is due Mr. Robert August of the State Planning Department for his excellent leadership of the Technical Task Force and to Mr. Melvin Scheidt whose experience in resource management and intimate knowledge of the Patuxent River served well the consulting needs of the Task Force.

The State's involvement in water pollution control stems from several sources well documented elsewhere. Several factors that punctuate the involvement in the Patuxent River Basin merit reiteration here.

1. The Patuxent River Basin is the largest river basin lying wholely within the boundaries of the State. The opportunity, as well as the responsibility, for water quality control lies solely within the confines of the State. The opportunity is not inhibited by interstate problems and the responsibility is not diluted by multi-state involvement.

2. Water quality in the Patuxent River is, as yet, not grossly degraded, although the trend in recent years has been one of gradual deterioration. An active program for pollution control at this time would represent more of a preventive effort than a corrective one. The opportunity to "save" a major water resource of the state from the too well known effects of serious pollution is an opportunity to exercise the true potential of a water pollution control program. 

3. By Act of the Maryland General Assembly (HB 702), a sum of $\$ 4$ million in bonds was authorized for matching and administering grants received from the Federal Government to develop comprehensive water quality control and abatement plans for river basins pursuant to Section 3 (c) of the Federal Water Pollution Control Act. In subsequent hearings before the House Natural Resources Committee, the Department of Water Resources (agency administering the program) was requested to give top priority to the Patuxent River Basin in this program.

State water quality surveillance programs of recent years show that sections of the main stem of the Patuxent River between Laurel and tidewater, and the Iittle Patuxent River from Savage to its mouth, have recurrently experienced water quality degradation in violation of the state Water Quality Standards. The Federal water Pollution Control Administrations Chesapeake Field Station, a valuable technical contributor to the Task Force, has applied systems analysis techniques to water quality data collected jointly by State and Federal water quality control agencies. The Field Station concluded that the Patuxent River system is incapable of sustaining the expected increase in waste loads without resulting in severe water quality degradation. It is apparent that this degradation can be arrested and controlled by managing the discharge of point source waste inputs to the basin.

Advanced waste treatment of all waste to achieve nutrient removal and a. high degree of B.O.D. removal presently appear to offer the most efficient and effective avenue for water quality control in the basin. By way of a meeting on February 16, 1968, the State Department of Health has already informed representatives of the principal waste dischargers that they should anticipate the need for advanced waste treatment. However, before recommending the adoption and implementation of a specific plan, the Departments of Health and Water Resources intend to further verify the predictive tools by means of a 

comprehensive field survey to be conducted in the summer of 1968 . These additional studies have been planned, in view of the large public expenditure that would be required to provide advanced waste treatment, to answer some significant uncertainties about the physical and biological properties of the river and, thus, allay any doubts that may arise from these uncertainties.

The remaining comments refer to the recommendations as summarized on pages iv, $v$, vi, and vii of the Report.

Recommendation :I

In reference to the flow release from Rocky Gorge Reservoir by WSSC the following regulations presently apply. The Commission is required to maintain a minimum flow at Laurel equivalent to the smaller of either $10.5 \mathrm{mgd}$ ( $16.5 \mathrm{cfs}$ ) or the natural flow that would be in the river at Laurel if there were no regulation or diversion. Assuming that the USGS stream gage near Unity (gage \#1-5910) is representative of the unregulated stream flow above Laurel, the following relationship can be used to determine the natural flow at Laurel.

$$
\frac{D \cdot A \cdot \text { above Laurel }}{\text { D.A. above Unity Gage }}=\frac{132}{34.8}=3.8
$$

Therefore, natural stream flow @ Laurel = $3.8 \mathrm{x}$ flow @ Unity Gage. Augmentation of the stream flow from WSSC reservoirs is not now required. In view of the CFS calculations, which indicate that the WSSC reservoirs contain sufficient capacity to provide some augmentation as well as meet the current water supply demands, the Commission together with the Department of Water Resources is engaged in a more detailed analysis to determine how much, if any, storage could be made available for flow augmentation.

\section{Recommendation $\cdot 2 \mathrm{a}$}

All owners of sewage treatment plants in the Patuxent Basin were instructed last August that they must operate so as to provide maximum attainable reduction of B.O.D. The achievement of this goal is being monitored through analyses of effluents from plants. 

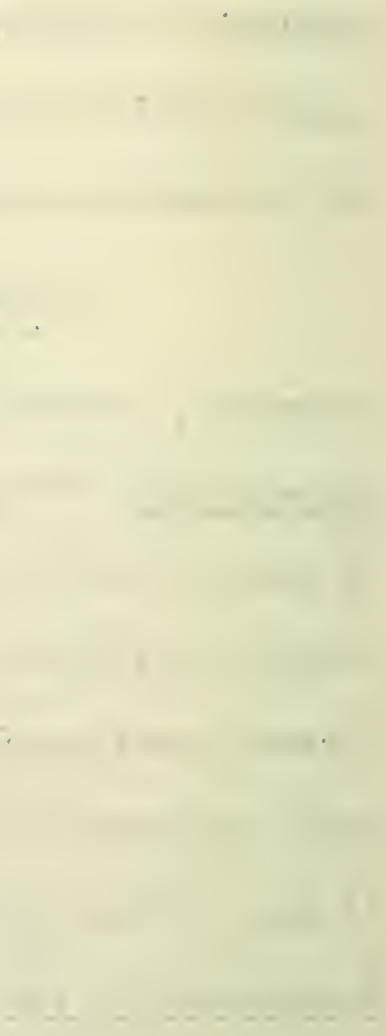
An intensive evaluation is under way of the present loading, capacity, and performance of each sewage treatment plant in the Patuxent Basin. This was initiated some months ago and will be concluded with the aforementioned survey to be made during the coming summer.

The results of this summer's survey and model verification activities will permit the identification of sewage treatment levels that will be required now and in the future to meet water quality standards.

The state Department of Health presently receives plans for proposed subdivisions in Howard and Anne Arundel Counties. These are reviewed in terms of adequacy of existing or proposed sewerage facilities. The Department will work through county health departments and other local agencies to develop this same review procedure promptly in the other Patuxent Basin counties. Recommendation $.2 \mathrm{~b}$ and $\mathrm{c}$

Both short range and long range programs for pollution control are being generated by the county water and sewerage plans that are required to be completed by January I, 1970, and by the river basin plan noted earlier.

In guiding the development of the county plans the achievement and maintenance of high water quality in the Patuxent Basin has been a major consideration. When these plans are completed, they will be approved only if they include adequate measures to insure the attainment of water quality standards. The same consideram tions will be paramount in the development of the river basin plan. Recommendation .3

In order to effectively implement a comprehensive water pollution control program that requires the cooperation of many governmental bodies, a coordinating committee will be required. Both the Federal and state enabling legislation of Section 3 (c) require that a basin organization representing all concerned agencies and jurisdictions be created to direct the planning program. Those agencies listed in recommendation 3 would probably all be included. 

The Department of Water Resources has assumed the responsibility of developing a mathematical model of the Patuxent estuary. The FWPCA Chesapeake Field Station has cooperated by providing field personnel to obtain certain necessary physical data, notably cross-sectional area measurements, on the upper Patuxent estuary. A preliminary version of the model to trace the longitudinal salinity distribution of the estuary has been completed. The Department anticipates the contract utilization of CBI dye study expertise to help define the dispersion characteristics of the upper estuary where salinity data is insufficient or lacking. Then completed, the model should be a useful tool for predicting the effect of various pollutional loads on the estuary and evaluating the expected effect of the proposed WSSC treatment plant at Western Branch.

\section{Recommendation .7}

The Department of Water Resources does not recommend that another committee should be established as outlined in item 7, page vi. Instead, with the staff on hand, the Department of Water Resources shall formulate a State-wide policy of erosion and sediment control. The policy shall be reviewed and comments requested before adoption from those groups listed in item 7 (as well as others). The policy can then be adapted to the requirements within the basin.

James B. Coulter, Assistant Commissioner Maryland Department of Health

Paul w. McKee, Director

Maryland Department of Water Resources 

THE MARYLAND - NATIONAL CAPITAL PARK AND PLANNING COMMISSION Regional Headquarters Building

8787 Georgia Avenue

Silver Spring, Maryland 20907

May 8, 1968

Mr. James J. O'Donnell, Director

State Planning Department

State Office Building

301 West Preston Street

Baltimore, Maryland 21201

Re: M-NCPPC Comment on Final Draft of Patuxent Report

Dear Mr. O'Donne II:

The "Report on a Re-examination of the Water and Related

Land Resource Problems of the Patuxent River Basin, "final

draft, prepared by Melvin E. Scheidt for the Maryland State

Planning Department, was circulated to The Maryland-National

Capital Park and Planning Commission and was discussed at the Commission meeting on April 17, 1968.

The Commission agreed in general with the Report, reserving specific comment for the population estimates used by the consultant in Table 1, Page 7, as they relate to Montgomery and Prince George's Counties. For purposes of comparison, the Commission submits the following totals:

\begin{tabular}{|c|c|c|c|c|c|}
\hline \multicolumn{6}{|c|}{ POPULATION TRENDS AND PROJECTIONS } \\
\hline $\begin{array}{l}\text { Montgomery } \\
\text { County }\end{array}$ & $\frac{1960 \frac{1}{7}}{340,928}$ & $4 9 \longdiv { 1 9 6 8 3 }$ & $508, \frac{19701}{100}$ & $643 \frac{1980 \pm}{4,400}$ & $99 \frac{2000 \frac{11}{5,000}}{4}$ \\
\hline $\begin{array}{l}\text { Prince George's } \\
\text { County }\end{array}$ & 357,395 & 615,500 & 623,700 & 792,9001 & $\overline{92,000}$ \\
\hline
\end{tabular}

I/ M-NCPPC Information Bulletin No. 9 - July, 1964

2/ As of January 1, 1967 - M-NCPPC Information Bulletin No. 12 - June, 1967

3/ As of January 1, 1968 - M-NCPPC Preliminary Estimates 

In adition, attached to this letter you will find a sheet listing the population estimates for the Patuxent River Basin by planning area for Montgomery and Prince George's Counties. This listing, by planning area, refers to the planning areas delineated on "The Master Plans Program for Montgomery and Prince George's Counties," dated March, 1967, which is already in the State Planning Department's possession.

I should further advise you that in conjunction with the preparation of the Comprehensive Water and Sewer PIan (10-Year) for Prince George's County, a Community Goals Advisory Committee prepared, for the Prince George's County Commissioners, a statement of County "Goals, Purposes and Concepts for Future Development," dated March 15, 1968. It is the premise of this document that "...the County's population will approximate I-1.2 million by 1980, the Committee recommends that the County take appropriate steps to accommodate this population."

\author{
Very truly jours, \\ /s/ John S. Hewins \\ John S. Hewins \\ Director of Planning
}

Attachment 

METROPOLITAN WASHINGTON

COUNCII OF GOVERNMENTS

1225 Connecticut Avenue, N.W.

Washington, D.C. 20036

May 17, 1968

Mr. James J. O'DonnelI

Director

Maryland State Planning Department

State Office Building

Baltimore, Maryland 21201

Dear Mr. O'Donnell:

The staff of the Council of Governments has reviewed the final draft of the Consultant's "Report On A Re-examination of the Water and Related Land Resource Problems of the Patuxent River Basin" prepared for the Maryland State Planning Department. Tie have found the report to be penetrating and thoughtprovoking and conceived in the recognition that the Patuxent Basin will assume incresingly greater importance as the interface between the fast-growing and potentially coalescing Baltimore and Washington Regions.

Mr. Melvin E. Scheidt, the Consultant, has correctly drawn attention to the magnitude and inter-relationships of the problems of environmental protection in the Patuxent Basin. As we all know, the purpose of planning for environmental protection is to assure the utilization and maintenance of our land, water and air resources for the maximum benefit of all citizens and visitors in the region. Because of this, the staff will support, to the limit of economic feasibility, those technologically oriented proposals of the Consultant which tend to provide for the protection and enhancement of all of the Basin's natural resources. These proposals appear to be soundly based in the light of currently available engineering knowledge and will lead in general to water quality, water supply, erosion control, and solid waste disposal cbjectives which the council has long supported. The Consultant's proposals for recreational development and open-space utilization deserve careful consideration because of the benefit they will bring to the entire region. In supporting these proposals, the Council assumes that adequate compensation will be made to owning agencies when their facilities or rights are converted to alternate uses.

The Consultant's proposals for the development of organizational arrangements to oversee land and water resource 

development in the Patuxent Basin reflect his long experience in both the Baltimore and Washington Regions, and his thorough knowledge of the administrative and political issues that must be met. The staff of the Council of Governments readily acknowledges that this knowledge and experience have been thoughtfully employed by the Consultant in his development of recommendations for organizational arrangements. We believe, however, that at this time it is essential that policy guidance be sought from the elected officials of all of the jurisdictions and agencies concerned before detailed organizational matters should be considered. Nevertheless, when organizational matters are eventually taken under advisement, the staff suggests that maximum overall benefits will be obtained through the use of existing agencies and coordinating councils whenever possible.

The staff of the Council of Governments wishes to thank you for the opportunity of offering our comments on this report.

Very truly yours,

/s/ John J. Ientz

John J. Lentz

Director of

Environmental Health 

REGIONAL PIANNING COUNCIL

701 st. Paul street

Baltimore, Maryland 21202

Niay 1, 1968

Mr. James J. O'Donnell, Director

State Planning Department

State Office Building

301 West Preston Street

Baltimore, Maryland 21201

Dear Jim:

This letter and the enclosed attachments represent this agency's review and comments on the consultant's report prepared for the Patuxent Technical Task Force. It should be noted that the technical material which may appear in appendices two, four, five and six was not included with the materials submitted for review. Consequently this could not be covered in our comments.

The staff does not wish to take a firm position at this time on the various ad hoc committees recommended in the report. It is felt that this matter should be left for policy determination by the officials and bodies appointed for the purpose of the continuing study. However, it is felt that if these committees are deemed necessary, the local representation should be made up of personnel from existing committees in the three regional areas.

We are in general concurrence with the structure of the suggested Patuxent Basin Council, including elected representatives who now also serve on the three regional agencies. However, it is believed that further discussion of this concept may be desirable on the part of the various policy bodies concerned.

If any questions should arise or further clarification is necessary regarding these comments, please call upon us.

Sincerely yours,

/s/ Robert N. Young

Robert N. Young

Executive Director

Enclosure 

STATE ROADS COMMISSION

300 west Preston Street

Baltimore, Md. 21201

April 1, 1968

Mr. Bob August, Planner

State Planning Department

State Office Building

30I W. Preston Street

Baltimore, Maryland 21201

Dear Mr. August:

The State Roads Commission has no particular comment on the draft final report of the Patuxent River Technical Task Force, except that we are willing to be represented on the Patuxent River Basin Erosion and Sediment Control Advisory Committee recommended on page 4l. If this group is, in fact, created, it is suggested that Mr. David H. Fisher, Chief Engineer-Deputy Director be requested to delegate a representative from the State Roads Commission.

The Bureau of Planning has heretofore provided the State Roads Commission delegate on the Task Force, but believes that the implementation of the findings of the group is now properly within the purview of an Operations Division.

If we can be of further assistance in this matter, please do not hesitate to call on us.

\author{
Very truly yours, \\ /s/Walter J. Addison \\ Walter J. Addison \\ Deputy Chief Engineer \\ Planning \& Safety
}

WJA :L:S 

Mr. Robert August

State Planning Department

Baltimore, Niaryland

\section{Dear Bob:} busy down here.

Sorry for the delay of this letter, things have been quite

I reviewed the report with Dr. Cronin and our general opinion is that it is an excellent and commendable effort. The perspectives presented should play a major role in influencing future management of the basin. We suggest no major changes or additions, except for a few minor points. In page $i i$, last sentence, might we suggest: "Studies currently planned by NRI and FTPCA will assist in providing some, but not all, the data and analysis required for such an understanding."

Question on page $v$, 2nd paragraph, Iine 5. Shouldn't this read "lower estuary or the bay"?

Page V\#4. Suggest establishment of a Coordinating Technical Committee made up of members, from the various listed departments, or agencies. The C.T.C. in turn interprets research findings etc. and reports to the Patuxent Basin Sanitary Advisory Committee.

Page vii, \#13. We would like to have seen included in this section mention of the need to obtain financial support for required research.

It has been a pleasure working with you and other committee members. I feel optimistic that as a result of the efforts, the Patuxent Basin will receive the attention necessary to develop and maintain a quality environment, a prerequisite for a quality society.

Sincerely,

/s/ Joseph A. Mihursky

Joseph A. Mihursky, Ph.D. Chairman, Environmental Research Department 



\section{WASHINGTON SUBURBAN SANITARY COMIISSION 4017 Hamilton Street \\ Hyattsville, Maryland 20781}

\section{April 17, 1968}

Mr. James J. OPonnell, Director

State Planning Department

301 W. Preston Street

Baltimore, Niaryland 21201

Subject: Review of Final Draft of Patuxent Report

Dear Ir. O'Donnell:

This is in reply to a memorandum from the State Planning Department requesting the comments of this Commission on the final draft of the "Report on a Re-examination of the vater and Related Land Resource Problems of the Fatuxent River Basin -- February 1 4 , 1968". The report was prepared by Melvin E. Scheidt with the assistance of the Patuxent Basin Technical Task Force of which this Commission is a member.

The Washington Suburban Sanitary Commission concurs generally in the findings and recommendations of the report subject to these qualifications, which I request jou to include in the report:

1. If it becomes necessary to release water from the Commission's reservoirs in excess of its present obligation the Commission would naturally expect equitable compensation.

2. It should be recognized that any recreational use of the Commission's reservoir areas must, of necessity, be compatible with their primary function as a source of water supply.

You can be assured of our continued cooperation in matters pertaining to water and related land resource management problems of the Patuxent River Basin.

$$
\begin{aligned}
& \text { Very truly yours, } \\
& \text { /s/ Robert J. McLeod } \\
& \text { General Manager and } \\
& \text { Chief Engineer }
\end{aligned}
$$





\title{
COMIENTS ON THE PATUXENT RIVER BASIN REPORT \\ PREPARED FOR THE MARYLAND STATE PLANNING \\ DEPARTIENT
}

\author{
BY \\ Melvin E. Scheidt, Consulting Engineer
}

The following comments comprise the major technical review of the Consultant's report by the Regional Planning Council staff. Complete technical review of appendices 2, 4, 5, and 6 was not possible since they were not included with the submittal. Some of these comments were presented orally at the task force meeting of April 19, 1968. The comments are as follows:

1. More emphasis on the immediate need for erosion control programs would appear warranted on pages iii, vi, vii, and more particularly on pages 42 and 43.

2. Anne Arundel County and Fort Meade anticipate fairly vast development of ground water supplies which would appear contradictory to comments on page iii.

3. On page $\mathrm{v}$ it is indicated that a basin wide program would justify payment by the Federal Water Pollution Control Administration of a 10\% premium on any grant needed in financing construction of sewerage facilities. The jurisdictions within the Baltimore and Washington Metropolitan Regions already qualify for this 10\% premium through the existence of regional planning activities.

4. The representation on the various proposed committees needs some clarification. Someone might assume from the way that it is now written that representation from all counties within the State is recommended. This clarification may be needed on page $v$, vii, and the last section of the report, particularly the last page.

5. The availability of federal funds for Open Space Acquisition should be taken into account in the first paragraph on page 2.

6. In the first paragraph on page 3 it is indicated that the Soil Conservation Service was on the task force. To the best of my knowledge they cooperated with the task force but were not members of the task force.

7. On the last paragraph on page $\sigma$, is the Washington Surburban Sanitary Commission release requirement tied into the inflow to the reservoirs?

8. Table $I$ on page 12 does not at all reflect the information we supplied on population. We project 90,000 to 110,000 people in Howard County in the basin by 1980. Howard County and the Rouse Company project even higher populations by that time. We were under the impression that this discrepancy 

would be corrected prior to publication of this report. In Anne Arundel County the figures are higher than we project, but this is believed to be largely due to non-residents in the Fort Heade area. This should be clarified. As it now appears, there would seem to be more population currently sewered than resides in the basin in Anne Arundel County. If the lowest projections, such as those indicated in this table for Howara County, are used in projections, such as those indicated in this table for Howard county, which the previous (196I) study is accused is being committed again. On the other hand, using the more conservative estimates (higher values) would do no harm, and should Columbia not begin to meet its expectatiors, the end result would merely be a slowing down of the programmed expenditures.

9. In the third paragraph on page 8 it may be implied that the Patuxent Watershed Act money is available for both local and state park acquisition since both local jurisdictions and the state are public agencies.

10. The last paragraph on page 8 would not appear to be borne out by tables $I$ and 2. There is no significant upward revision of population projections from the 1961 report. The 1980 projection now presented is only 10\% higher which would appear extremely insignifj.cant for such projections. There is no difference between the projections for the year 2000 .

11. In the next to last paragraph on page 9, there would appear to be some error. The Maryland National Capital Park and Flanning Commission is not a regional agency, nor is there a sanitary department in Anne Arundel County. The department in Anne Arundel County responsible for sanitary facilities is the Department of Public Works.

12. On page 10 in the second paragraph under "Problems of the basin", the last sentence would not always be true. Reduced quantity of flow may affect downstream use, but downstream water quality and downstream use need not always be affected if the withdrawal is properly treated and returned to the stream.

13. In the next to last paragraph on page Il, it does not even appear true that the two topics which are strictly approached from a basin point of view can be thus classified. Waste may be pumped into or out of the basin (such is now the case) and the estuary relates to recreation and food supplies within and outside the basin.

14. In table 3 there is a column headed "Type of Treatment" this is not a very meaningful term. It is suggested that per cent BOD removal replace this column. It was understood that approximate values for this parameter were developed by the State Department of Health during the course of the Task Force's activities. It might also be noted in this table that there is a misplaced decimal point in the volume for the Fort lieade number 1 plant. This value probably should be $1.2 \mathrm{mgd}$ rather than $1200 \mathrm{mgd}$.

15. On page 17 , item 2 , in the last sentence "waste discharges into the headwaters of western branch" is indicated. In comparing this statement with table 3 , the only discharges into the western branch would appear to be 


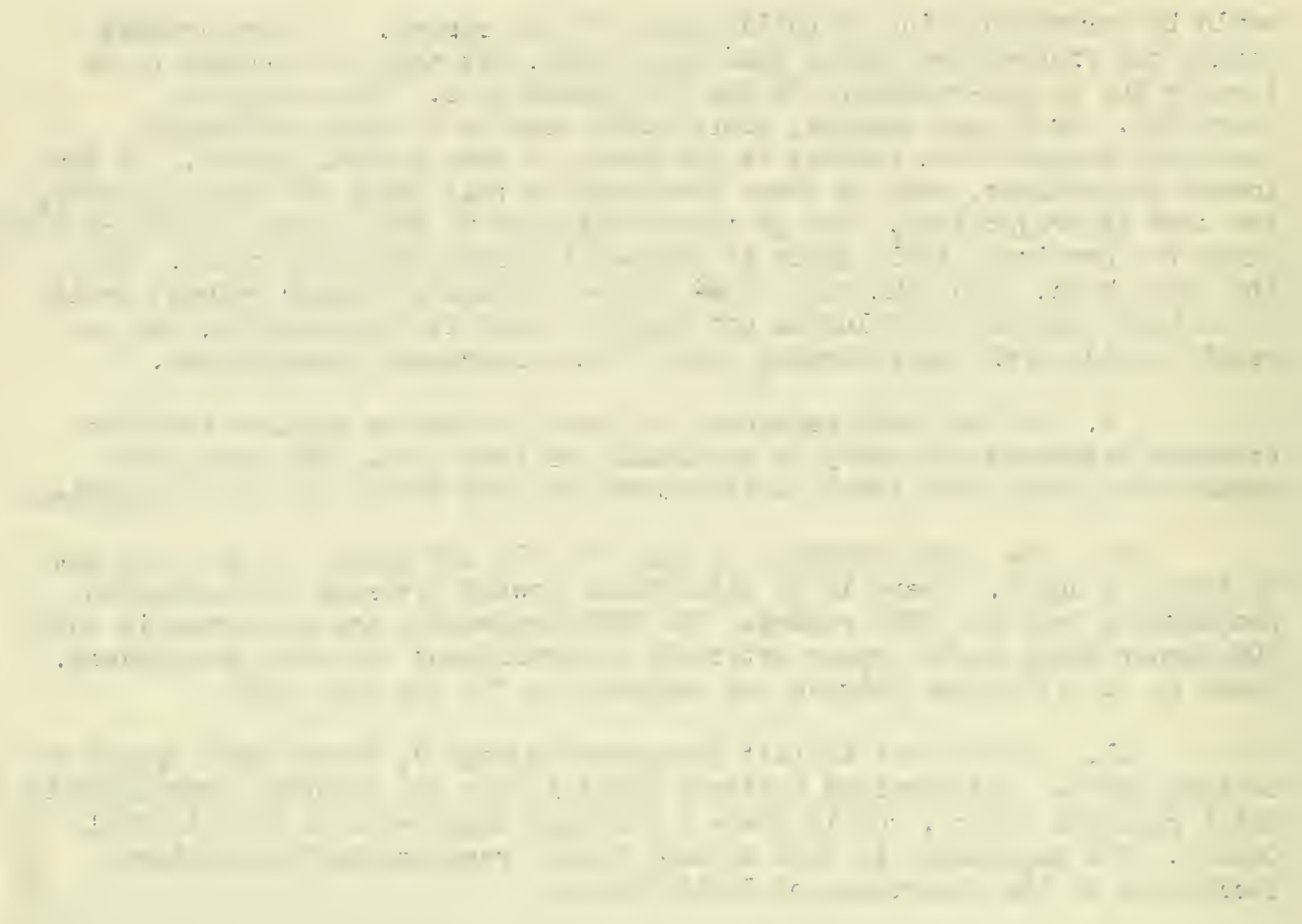

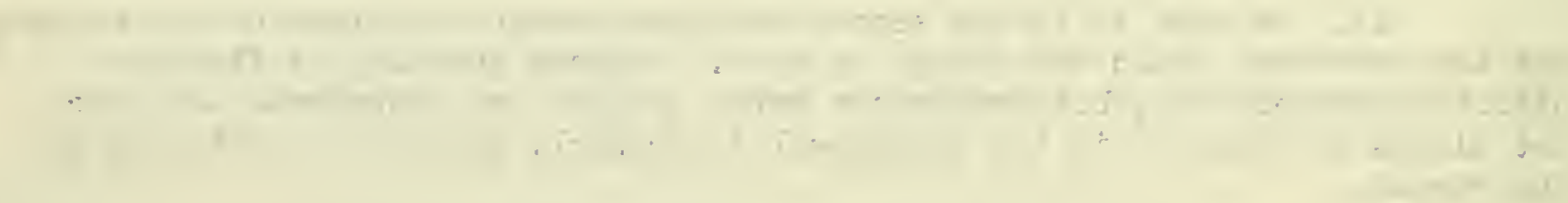

.

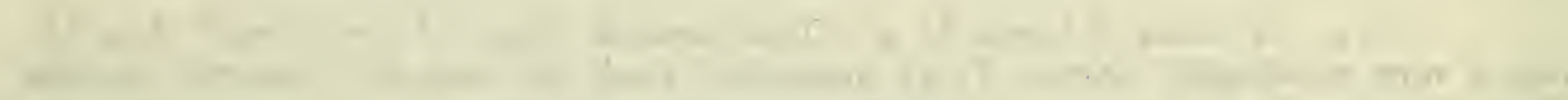

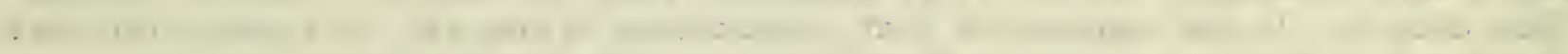

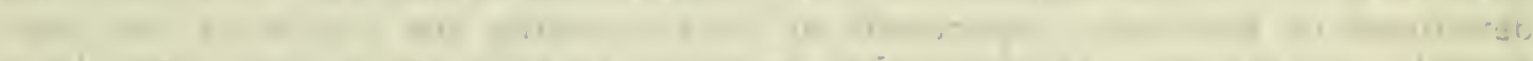
$1+2 \ldots+1, \ldots$

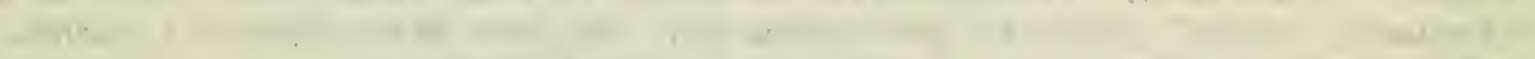

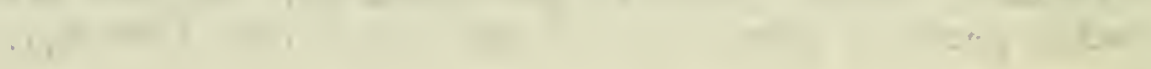
- 
from Upper Ifarlboro, which would not appear to be headwaters of the stream.

16. On page 18, under item 5, reference is again made to population projections and that these were developed in cooperation with the regional agencies. There appears to have beer no consideration given to the projections and land use information compiled and supplied by this agency.

17. In the third paragraph, on page 19, some mention should probably be made of the present illegal practice of some septic tank pumping contractors who will misuse waters by dumping the sewage directly into the streams at night or in some remote area in hopes they will not be detected. Some patrol activities to prohibit the occursence of this practice might be suggested.

18. At the end of the last paragraph on page 19, the following statement might be added, "Uniform charges throughout the state would not be inequitable, since the benefits accruing from improved water quality would not be limited to residents of the area but to everyone utilizing the basin and/or the estuary for recreational and other purposes."

19. On page 21, the phosphorous and nitrogen problems in the estuary and the river are discussed. It has been stated by others that at Bethlehem Steel Co. where the effluent from the Back Fiver sewage Treatment plant is used for industrial purposes, the phosphorous is tied up in some complex ion and becomes unavailable to the biota of the receiving waters. It might be suggested that an investigation of the possible complexing of phosphorous and/or nitrogen be undertaken.

20. In the first paragraph on page 22, there appears to be some discrepancy with some recently reported costs for complete renovation of waste waters. An additional cost of $5 \phi$ to $10 \phi$ per 1,000 gallons for complete renovation above secondary treatinent costs was recently quoted.

21. In the last sentence in the third paragraph on page 22, the Waste Acceptance Service would not appear to require cooperative planning, but should provide it, if implemented.

22. In the fourth paragraph on page 22, the effects of stream quality on the ecology of the ocean is not mentioned. It is also understood that a stream monitoring program has now been established for the Patuxent River as well as other waters of the State.

23. On page 23, it appears that items 4 and 10 are duplications.

24. Consideration of the effects of the river on the food chain and ecology of the ocean are again neglected.

25. At the top of page 30, it is indicated that the four upper counties now have membership on one or more of the metropolitan regional planning agencies. This is incorrect - each county is represented on only one metropolitan regional agency. 

26. In the next to last paragraph, on page 31 , shouldn't it be indicated that the program developed by the Maryland National Capital Park and Planning Commission is coordinated with the Patuxent Watershed Act, and not separate theirefrom?

27. In the last paragraph, on page 31, it is not indicated that the major pollution problems in the streams of Baltimore are past neglect of sanitary sewage problems. In many areas these streams have been put in conduits and are not faced with the problems of encroachment. Acquisition of lands along the waterway do not prohibit misuse of adjacent banks. What is really required is a strict enforcement of existing regulations regarding open dumping and littering, along with an adequate acquisition program.

28. In the first full paragraph on page 33, should a suggestion be made that priorities be developed and possible flunding alternatives considered? Should the funding alternatives, such as a special ear-marked tax levy, as is now used in Prince Georges and Montgomery Counties be suggested?

29. In the third paragraph from the bottom on page 33, acquisition is again indicated as a method of controlling indiscriminate dumping. Without proper enforcement of existing regulations and elimination of access to undeveloped park areas, this would not appear to offer any solution. Supervision, policing, ano cleanup of existing developed park areas is always required.

30. In the next to last paragraph on page 36, the Regional Planning Council is not a voluntary agency, but is a state agency set up by legislation.

31. In the next to last paragraph on page 40, the words "agencies, councils," are redundant.

32. On page 42, the last sentence, under "Further Investigations in the Estuary", coordination with the Park and Recreation Advisory Committee should also be indicated. 



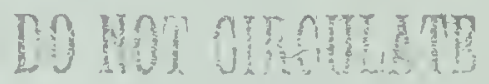




